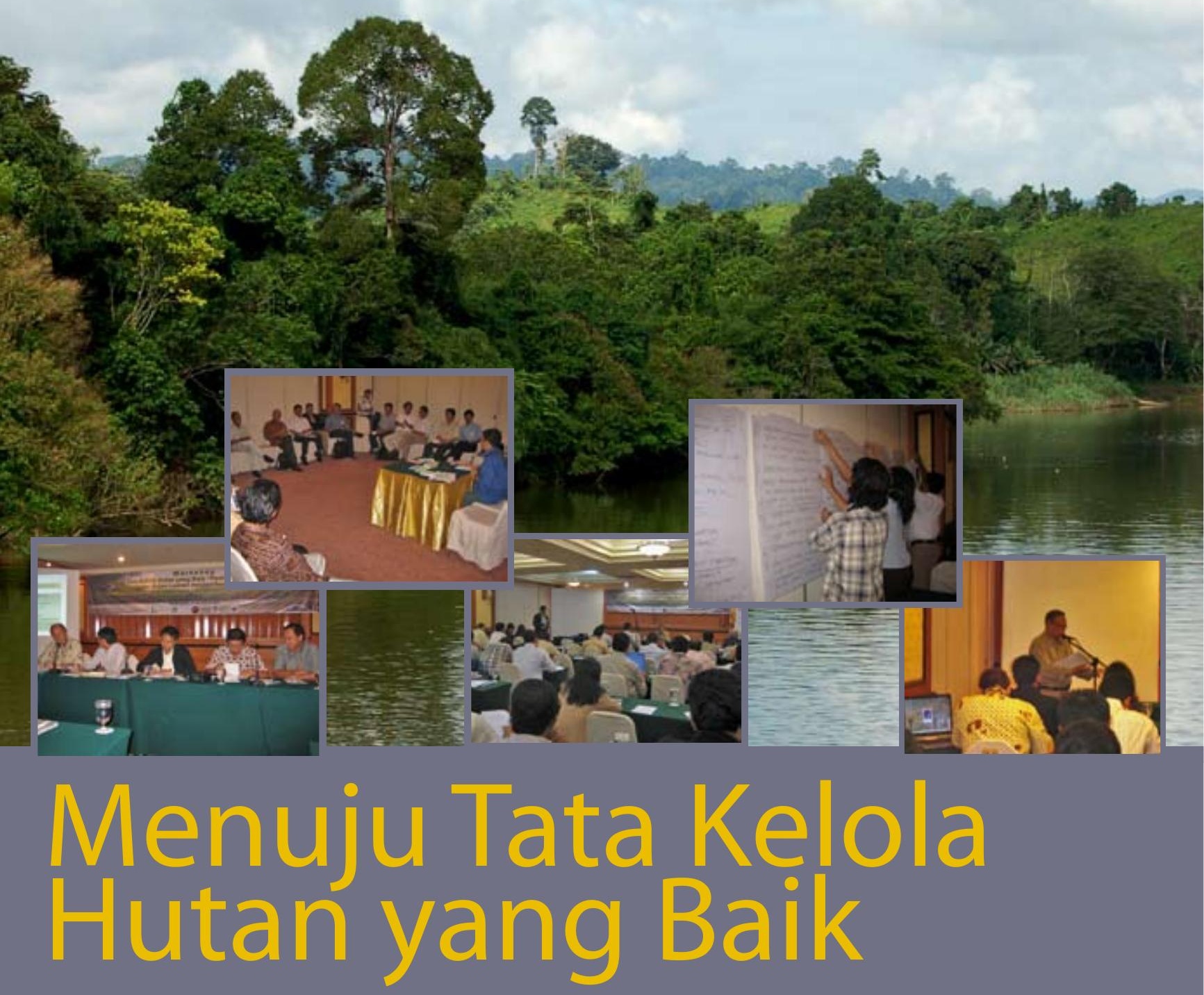

Peningkatan Implementasi Pengelolaan Hutan Lestari Melalui Sertifikasi Hutan dan Pembalakan Ramah Lingkungan (Reduced Impact Logging - RIL)

\title{
Prosiding Lokakarya
}

Penyunting:

Hari Priyadi, Ahmad Wijaya, Petrus Gunarso, Agung Prasetyo, Tetra Yanuariadi Mustofa Agung Sardjono, Alfan Subekti, Ahmad Dermawan dan Kresno Dwi Santosa 


\section{Menuju Tata Kelola Hutan yang Baik}

Peningkatan Implementasi Pengelolaan Hutan Lestari melalui Sertifikasi Hutan dan Pembalakan Ramah Lingkungan (Reduced Impact Logging - RIL)

Prosiding Lokakarya

Penyunting

Hari Priyadi

Ahmad Wijaya

Petrus Gunarso

Agung Prasetyo

Tetra Yanuariadi

Mustofa Agung Sardjono

Alfan Subekti

Ahmad Dermawan

Kresno Dwi Santosa 
Priyadi, H. et.al. (eds.)

Menuju tata kelola hutan yang baik: peningkatan implementasi pengelolaan hutan lestari melalui sertifikasi hutan dan pembalakan ramah lingkungan (Reduced Impact Logging - RIL): Prosiding lokakarya, Balikpapan, 21-23 Juni 2006/ed. by Hari Priyadi, Ahmad Wijaya, Petrus Gunarso, Agung Prasetyo, Tetra Yanuariadi, Mustofa Agung Sardjono, Alfan Subekti, Ahmad Dermawan, Kresno Dwi Santosa. Bogor, Indonesia: Center for International Forestry Research (CIFOR), 2007.

ISBN: 978-979-24-4689-2

80p.

CABI thesaurus: 1 . forests 2 . governance 3 . certification 4 . reduced impact logging 5 . biodiversity 6. nature conservation 7 . constraints 8 . incentices 9 . Indonesia 10 . conferences I. Title

Desain \& Tata Letak oleh Vidya Fitrian dan Eko Prianto

Foto sampul depan dan belakang oleh Yukina Uitenboogaart

@ 2007 oleh Center for International Forestry Research

Hak cipta dilindungi oleh Undang-undang

Dicetak oleh SUBUR Printing, Jakarta

Diterbitkan oleh

Center for International Forestry Research (CIFOR)

Alamat Pos: P.O. Box 6596 JKPWB, Jakarta 10065, Indonesia

Alamat Kantor: Jalan CIFOR, Situ Gede, Sindang Barang,

Bogor Barat 16880, Indonesia

Telp.: +62 (0251) 622622. Fax.: +62 (0251) 622100

E-mail:cifor@cgiar.org

Situs web: http://www.cifor.cgiar.org 


\section{Daftar Isi}

Daftar Singkatan vi

Kata Pengantar $\quad$ ix

Executive Summary $\quad x$

Background $x$

Objectives $\quad$ xi

Outputs xi

The Workshop xii

Workshop Results xii

Sambutan Pembukaan 1

Sambutan Ketua Penyelenggara 3

Sambutan Kepala Dinas Kehutanan Provinsi Kalimantan Timur 5

Sambutan Dirjen BPK Departemen Kehutanan 9

$\begin{array}{ll}\text { Kerangka Acuan } & 13\end{array}$

$\begin{array}{ll}\text { Latar Belakang } & 13\end{array}$

$\begin{array}{ll}\text { Tujuan } & 14\end{array}$

$\begin{array}{ll}\text { Keluaran } & 14\end{array}$

Skema Alur Lokakarya $\quad 14$

$\begin{array}{ll}\text { Presentasi } & 15\end{array}$

$\begin{array}{ll}\text { Materi } & 17\end{array}$

Presentasi Sesi 1. Tata Kelola Pemerintahan yang Baik

$\begin{array}{lr}\text { (Good Corporate Governance) } & 18\end{array}$

Presentasi 1. Alfan Subekti (TBI) 19

Presentasi 2. Agung Prasetyo (CIFOR) 19

Presentasi 3. Prof. Soeyitno Soedirman (KKS-Unmul) 19

Presentasi 4. Loy Jonnes (Smartwood) 20

$\begin{array}{ll}\text { Panel Diskusi } & 20\end{array}$ 
Presentasi Sesi 2. Reduced Impact Logging (RIL) dan Pembelajarannya 24

Presentasi 1. Art Klassen dan Hasbilah (TFF) 24

Presentasi 2. Gusti Hardiyansah (PT SBK) 25

Presentasi 3. Boby Bayu (PT SLJ II) 25

$\begin{array}{ll}\text { Panel Diskusi } & 26\end{array}$

Presentasi Sesi 3. Sertifikasi dan Keanekaragaman Hayati pada

$\begin{array}{ll}\text { Hutan Produksi } & 28\end{array}$

Presentasi 1. Aditya Bayunanda (LEI) 29

Presentasi 2. Irwan Gunawan (WWF-Nusa Hijau) 29

Presentasi 3. Tetra Yanuariadi (WWF) 29

Presentasi 4. Petrus Gunarso (CIFOR) 30

$\begin{array}{ll}\text { Panel Diskusi } & 30\end{array}$

Isu-isu Strategis $\quad 32$

Diskusi Kelompok $\quad 35$

Acuan Diskusi Kelompok $\quad 37$

Kelompok 1. RIL dan Pembelajarannya $\quad 37$

Kelompok 2. Sertifikasi dan Keanekaragaman Hayati 37

Proses dan Hasil $\quad 38$

Kelompok 1. RIL dan Pembelajarannya 38

Kelompok 2. Sertifikasi dan Keanekaragaman Hayati 44

Presentasi Kelompok dan Diskusi Pleno $\quad 49$

Kelompok 1. RIL dan Pembelajarannya $\quad 51$

$\begin{array}{ll}\text { Presentasi } & 51\end{array}$

Tanggapan $\quad 53$

Kelompok 2. Sertifikasi dan Keanekaragaman Hayati (Kehati) 55

$\begin{array}{ll}\text { Presentasi } & 55\end{array}$

Tanggapan $\quad 58$

Perumusan Hasil dan Rekomendasi $\quad 59$

$\begin{array}{ll}\text { Proses } & 61\end{array}$

Hasil $\quad 62$

Kesimpulan $\quad 62$

Rekomendasi $\quad 64$

$\begin{array}{ll}\text { Penutup } & 65\end{array}$

$\begin{array}{ll}\text { Sambutan Ketua Penyelenggara sekaligus Penutupan } & 67\end{array}$

$\begin{array}{ll}\text { Lampiran } & 69\end{array}$

1. Daftar peserta lokakarya $\quad 71$

2. Agenda lokakarya $\quad 78$ 


\section{Daftar Singkatan}

ACM

APHI

BPDAS

BPK

BPPK

BTRF

$C \& I$

CBD

CIFOR

CITES

$\mathrm{CoC}$

CSF

CSR

DAS

Dishutbun

EU

FKPHD

FORDA

FP

FPP

FSC

FTN

GCG

GCP

GFG

GG

GIS

GTZ

HCVF
Adaptive Collaborative Management

Asosiasi Pengusaha Hutan Indonesia

Badan Pengelola Daerah Aliran Sungai

Bina Produksi Kehutanan

Balai Penelitian dan Pengembangan Kehutanan

Borneo Tropical Rainforest Foundation

Criteria \& Indicator

Convention on Biological Diversity

Center for International Forestry Research

Convention on International Trade in Endangered Species

Chain of Custody

Center for Social Forestry

Corporate Social Responsibility

Daerah Aliran Sungai

Dinas Kehutanan dan Perkebunan

European Union

Forum Kerjasama Pengelolaan Hutan Daerah

Forestry Research and Development Agency

Forest Partnership

Forest Partnership Program

Forest Stewardship Council

Forest Trade Network

Good Corporate Governance

Ground Control Point

Good Forest Governance

Good Governance

Geographical Information Systems

Deutsche Gesellschaft fuer Technische Zusammenarbeit

High Conservation Value Forest 


$\begin{array}{ll}\text { HLGL } & \text { Hutan Lindung Gunung Lumut } \\ \text { HoB } & \text { Heart of Borneo } \\ \text { HPH } & \text { Hak Pengusahaan Hutan } \\ \text { HPHKM } & \text { Hak Pengusahaan Hutan Kemasyarakatan } \\ \text { HTI } & \text { Hutan Tanaman Industri } \\ \text { IPK } & \text { Ijin Pemanfaatan Kayu } \\ \text { ISO } & \text { International Standards Organization } \\ \text { ITTO } & \text { International Tropical Timber Organization } \\ \text { IUCN } & \text { International Union for the Conservation of Nature and Natural } \\ & \text { Resources (World Conservation Union) } \\ \text { IUPHHK } & \text { Ijin Usaha Pemanfaatan Hasil Hutan Kayu } \\ \text { JPT } & \text { Jatah Produksi Tebangan Tahunan } \\ \text { Kalbar } & \text { Kalimantan Barat } \\ \text { Kaltim } & \text { Kalimantan Timur } \\ \text { KBK } & \text { Kawasan Budidaya Kehutanan } \\ \text { KBNK } & \text { Kawasan Budidaya Non Kehutanan } \\ \text { Kehati } & \text { Keanekaragaman hayati } \\ \text { KKN } & \text { Korupsi, Kolusi, dan Nepotisme } \\ \text { KKS } & \text { Kelompok Kerja Sertifikasi } \\ \text { LEI } & \text { Lembaga Ekolabeling Indonesia } \\ \text { LIPI } & \text { Lembaga Ilmu Pengetahuan Indonesia } \\ \text { Litbang } & \text { Penelitian dan Pengembangan } \\ \text { LPI } & \text { Lembaga Penilai Independen } \\ \text { LSM } & \text { Lembaga Swadaya Masyarakat } \\ \text { MRF } & \text { Malinau Research Forest } \\ \text { NGO's } & \text { Non-Governmental Organisation } \\ \text { NTFP } & \text { Non-Timber Forest Product } \\ \text { PAD } & \text { Pendapatan Asli Daerah } \\ \text { PBB } & \text { Pajak Bumi dan Bangunan } \\ \text { PeMA } & \text { Persatuan Masyarakat Adat } \\ \text { Persaki } & \text { Persatuan Sarjana Kehutanan Indonesia } \\ \text { PHPL } & \text { Pengelolaan Hutan Produksi Lestari } \\ \text { PR } & \text { Public Relations } \\ \text { PT KBT } & \text { Perseroan Terbatas Kemakmuran Berkah Timber } \\ \text { PT SBK } & \text { Perseroan Terbatas Sari Bumi Kusuma (Alas Kusuma Group) } \\ \text { PT SLJ II } & \text { Perseroan Terbatas Sumalilndo Lestari Jaya II } \\ \text { RIL } & \text { Reduced Impact Logging } \\ \text { RKL } & \text { Rencana Karya Lima Tahunan } \\ \text { RKT } & \text { Rencana Karya Tahunan } \\ \text { RTRWK } & \text { Rencana Tata Ruang Wilayah Kabupaten } \\ \text { RTRWP } & \text { Rencana Tata Ruang Wilayah Provinsi } \\ \text { SDH } & \text { Sumberdaya Hutan } \\ \text { SDM } & \text { Sumberdaya Manusia } \\ \text { SFM } & \text { Sustainable Forest Management } \\ \text { SK } & \text { Surat Keputusan } \\ & \end{array}$




$\begin{array}{ll}\text { SKSHH } & \text { Surat Keterangan Sah Hasil Hutan } \\ \text { TBI } & \text { Tropenbos International } \\ \text { TFF } & \text { Tropical Forest Foundation } \\ \text { TNC } & \text { The Nature Conservancy } \\ \text { TNKM } & \text { Taman Nasional Kayan Mentarang } \\ \text { TPTII } & \text { Tebang Pilih Tanam Indonesia Intensif } \\ \text { TUK } & \text { Tata Usaha Kayu } \\ \text { UM } & \text { Unit Manajemen } \\ \text { UNDP } & \text { United Nation Development Program } \\ \text { Unmul } & \text { Universitas Mulawarman } \\ \text { WWF-Indonesia } & \text { Worldwide Fund for Nature - Indonesia Program }\end{array}$




\section{Kata Pengantar}

Lokakarya Menuju Tata Kelola Hutan yang Baik "Peningkatan Implementasi Pengelolaan Hutan Lestari melalui Sertifikasi Hutan dan Pembalakan Ramah Lingkungan" yang diselenggarakan oleh CIFOR-MRF dan The Forest Partnership (Tropenbos-CIFOR-WWF) pada tanggal 21-23 Juni 2006 di Hotel Adika Bahtera Balikpapan telah dilaksanakan dengan sukses. Sekitar 60 peserta yang terdiri dari wakil-wakil institusi kehutanan pemerintah pusat dan daerah (Departemen Kehutanan, Dinas Kehutanan Provinsi Kalimantan Timur) perusahaan kehutanan, perguruan tinggi, pers, lembaga swadaya masyarakat, dan lembaga kerjasama internasional berperan aktif dalam acara tersebut.

Prosiding ini merupakan kumpulan dari keseluruhan acara lokakarya, berupa sambutan, kerangka acuan, presentasi dan tanya jawab, serta hasil-hasil diskusi kelompok, rumusan hasil diskusi pleno, dan rumusan hasil lokakarya. Secara keseluruhan isi prosiding dan tata urutannya menyesuaikan dengan agenda lokakarya yang diadakan.

Berbagai pihak telah memberikan dukungan sehingga pelaksanaan lokakarya ini mencapai hasil sesuai dengan tujuan dan hasil yang diharapkan. Sehubungan dengan itu pada kesempatan ini kami menyampaikan penghargaan dan ucapan terima kasih setulus hati.

Harapan kami adalah bahwa prosiding ini tidak hanya menjadi dokumen formal dari hasil pertemuan, akan tetapi lebih dimanfaatkan sebagai acuan bagi berbagai pihak yang mendukung penyelenggaraan program pengelolaan hutan yang lestari melalui sertifikasi dan pembalakan hutan ramah lingkungan (Reduced Impact LoggingRIL) baik pada tingkat birokrasi maupun pada tingkat implementasi.

Bogor, 2007

Tim Penyunting 


\section{Executive Summary}

\section{Background}

Sustainable Forest Management (SFM) depends, among others, on the extent and quality of enabling policies as well as legal and institutional conditions stemming from improving/good forest governance. It is important to note that underlying causes of forest problems such as deforestation and forest degradation are often multi-sectoral in nature. Therefore, understanding policies that become the underlying forestry problems is necessary. The relationship between governments, private sector, and communities is a key factor to improve preconditions for Good Forest Governance (GFG). Governments have to define their role towards efficient bureaucratic/ administration procedures and better land use allocation. After laws and regulations are in place and a healthy business environment is in place for the private sector, they should apply principles of best forest practices in a manner that also benefits local communities. This activity also addresses the need to develop partnerships between many active parties and stakeholders, linking improved forest governance in Kalimantan (Indonesian Borneo) with international market.

In relation to that, efforts have been made by various initiatives and project including forestry programs by CIFOR/ITTO, GTZ, Tropenbos, the EU, WWF, and TNC, that have been tracked and adapted to Indonesia's process of decentralizing natural resource governance. All effort mainly aiming at improving preconditions for best forest practices including implementation of forest certification, biodiversity conservation and mitigating environmental damage through implementation of Reduced Impact Logging and Social Conflict resolution over natural resources management.

CIFOR and its partner (PT Inhutani II, FORDA, LIPI, TFF and District of Malinau) had done tremendous works in relation with RIL both in research and development since 1997 during ITTO Phase I implementation (1997-2001). Trial of RIL in operational scale was successfully conducted in conjunction with PT Inhutani II harvesting schedule. This trial was along with study on impact of RIL on residual stand, canopy opening, skidtrail, logging damage and so forth. Study on RIL cost and benefit were also conducted during that period. Following this trial, it is noted that PT Inhutani II has tried to implement RIL in their concession gradually. 
In the development process, CIFOR has worked mainly in enhancing capacity building with various ways such as conducting several RIL trainings and its relevant techniques as follows: Training on Directional felling and skidding (1998), Contour and Tree Mapping (1999), Road Engineering (Roadeng) I \& II (1999 and 2000), RIL training (2005). Those activities were not only involving timber companies but also local community and district officials. We think that they are also an asset and having a significant link since they are also part of stakeholder in managing forests.

One of the most impact in national level have been made from research and development RIL related activities is the decree issued by Ministry of Forestry in 2001, SK No. 274/VI-PHA/2001 says that all timber companies in Indonesia must implement RIL in their concession following. However, such decree is still need to be enforced on the ground and incentives should be given to those companies who have been implementing proper RIL techniques (Jakarta Post, 2005). Meanwhile there is an effort that RIL should be promoted in district level by having support from district law (Kaltim Post, 2005). It means that RIL adoption is being challenged.

\section{Objectives}

\section{Workshop objectives as follows:}

1. To promote certification as a mean toward good forest governance and sustainable forest management, as well as to strengthen the network among government, private sector and civil society on certification

2. To learn about current certification process, identify incentives and disincentives from certification for the timber company and identify agreed steps to move forward

3. Identify current implementation of RIL by timber company

4. Define what are the benefits and constraints in RIL adoption

5. Define what incentives are expected from timber company

\section{Outputs}

Expected outputs derive from the workshop as follows:

1. Participants could identify constraints, incentives and disincentives in implementing best forest practices (e.g. RIL)

2. Increase understanding certification practices and well informed the opportunity and challenges global market condition

3. Able to understand conservation biodiversity in tropical production forest

4. Better understanding on good forest governance

\section{The workshop}

The workshop was held in Semayang's conference room at Hotel Bahtera, Balikpapan East Kalimantan. It was attended by more than 60 participants. They are from various representatives such as: concession company, government (central, provincial 


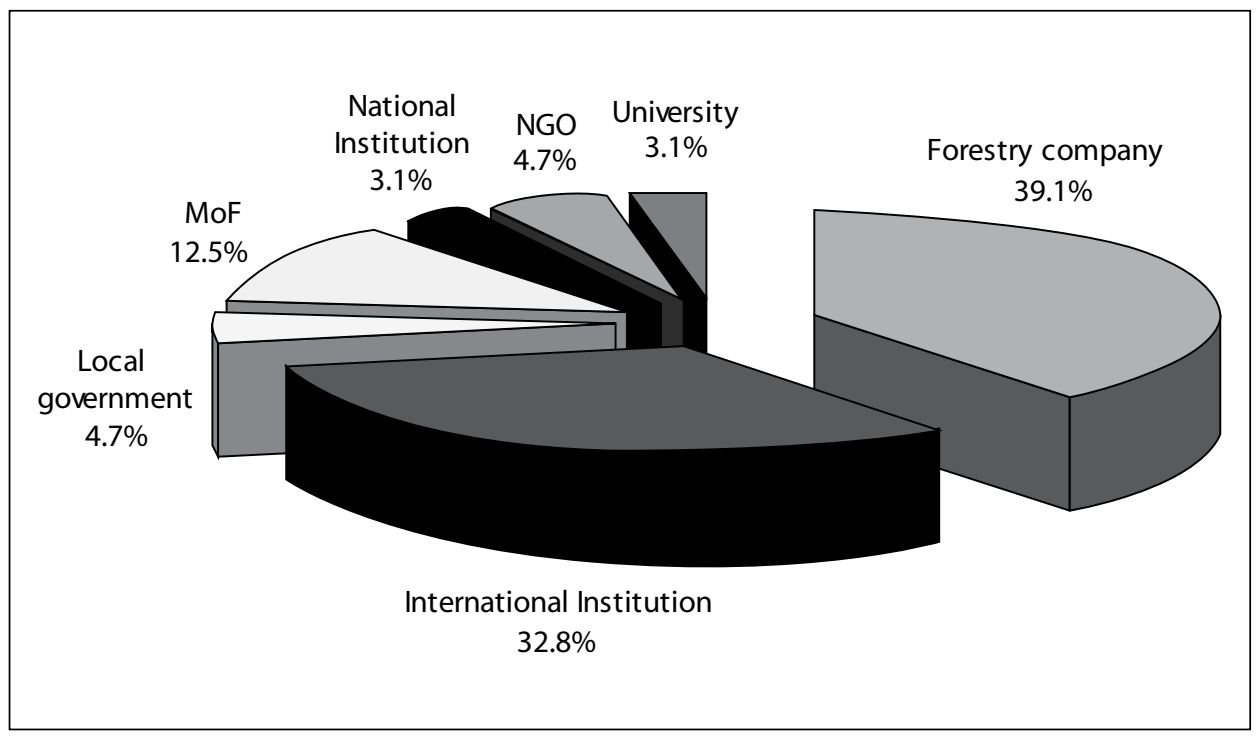

Figure 1. Break down of participants from different background (total participants: 64 persons)

and districts), academia, NGO's, Informal Forum (task force), and international institution (see attached list of participants). Most of them were from timber.

The workshop was officially opened by Head of Provincial Forest Services, East Kalimantan, Mr. Ir. H. Rusdi Manaf, MSi. On the first day, invited speakers presented various issues in three consecutive sessions, such as: 1) Good forest governance; 2) Reduced-impact logging: shared learning; and 3) Forest certification and biodiversity and its sustainable use in the tropical production forest. Participants were very active in discussion, questions and answers.

The agenda of the second day of the workshop ( $22^{\text {nd }}$ June) was a group discussion. There were two group discussions, namely 1) RIL and lessons learned; and 2) Biodiversity and certifications. Each group consists of 20-25 people. After intensive discussion, representative of each group delivered important issues/findings noted from group discussions.

The third day of the workshop (23 ${ }^{\text {rd }}$ June) was used for a field trip to Sungai Wain protected forest located about $15 \mathrm{~km}$ from the city of Balikpapan. Heat forest and dipterocarp trees were the most view during the trip.

\section{Workshop results}

\section{Some conclusions}

1. Indonesian forests, especially in East Kalimantan is facing a rapid deforestation rate which lead to not only local but also global threat (national deforestation rate is estimated about 3.6 million hectares annually. In Kalimantan itself, it is estimated 300,000 - 500,000 hectares annually). The worrying deforestation rate above needs firm and collaborative actions within a good forest governance atmosphere. 
2. Good forest governance is defined as interinstitutional mechanisms to manage natural resources to be well implemented according to current law, accountability, transparency and democratization as well as active participation among stakeholders.

3. Active participation among forest stakeholders should begin in early process of decision making that is under government policy (central, provincial and district) and also in its implementation by concession holders in order to achieve sustainable forest management.

4. Sustainable forest management could be achieved by implementing best forest harvesting (e.g. reduced impact logging) and greater involvement with forest certification scheme.

5. Experiences of concession holders shows that RIL implementation needs several preconditions such as trained staff and support from company's management. However, RIL implementation is proven to give a direct economic benefit to the company, while indirect benefit is gained through better vegetation regeneration such as potential crop trees or residual stands (in turn could remove cost for enrichment planting), clear forest area border, continuity beneficiaries on ecology (hidro-orology and biodiversity benefits). When RIL is well implemented on the ground, most of the criteria and indicators of sustainable forest management are basically met.

6. On the issue of biodiversity, economic value for timber is estimated only five percent of total functions and benefits of forest resources. The rest is covered by Non-Timber Forest Products (NTFPs) and environmental services. Therefore, detailed information on biodiversity (flora and fauna) plays an important role in the preparation of implementation resource-based forest management.

7. Beside RIL benefits, related experiences in the implementing intensive silviculture (i.e. intensive clear cutting and replanting system or sistem silvikultur Tebang Pilih Tanam Indonesia Intensif (TPTII) shows its ability in enhancing forest productivity in the shorter cycle. As well as RIL, TPTII also needs serious support from top management and availability of database in forest management unit. Overall, incentive from government on its implementation is expected.

8. The success in getting SFM certification need a long and proper preparation, as well as support from the company's owner. However, the most crucial issue to be solved by government in collaboration with all stakeholders is those related to land uncertainty.

9. Task force in certification (Kelompok Kerja Sertifikasi-KKS) was formed to answer the crucial need of forest certification in East Kalimantan. Most of concession holders show their enthusiasms in getting SFM certificate. The KKS is established since 2001 to answer this need. However, revitalization is needed in order to be effectively workable. 
10. From the workshop we found that only few timber companies implement RIL in Indonesia. This is due to some factors both internal and external, among others: lack of socialization of related government policy (e.g. Letter from DG PHA of MoF no. 274/VI-PHA/2001 about obligation to implement RIL by timber company), further training and course to enhance understanding on RIL taking into account financial and ecological benefit both for timber company and forest services, business uncertainty (policy changes), and more importantly examples of incentives given to the company that already implement RIL and or certification process (such as self assessment, premium price).

\section{Recommendations for further action}

1. Dissemination of knowledge and policy regarding with RIL and High Conservation Value of Forests (HCVFs) and also certification is recommended not only for timber company but also for forest related officers through trainings, workshops, an seminars. This is to achieve the same level of perceptions and understandings among forest related stakeholders.

2. The participants clearly express their concern regarding incentives. It is strongly suggested to government and company owners to give incentives to those who seriously implementing RIL (both company and individuals)

3. In response to testing of ITTO Guidelines for Conservation and Sustainable Use of Biodiversity in tropical Timber Production Forests, translation into Indonesian language of the guideline is recommended by most of the participants. Further planning to conduct field testing of the ITTO Guidelines through a 'bottomup" process is recommended.

4. Governments at all levels (Central, Provincial and Districts) are expected not to make implementation on SFM (including RIL and HCVFs) harder and difficult, primarily on financial and administration to timber companies.

5. In order to achieve SFM, there is a need a synchronized policy and regulations, not only in the managing natural resources but also the most important issue is on the proper and consistent implementation of integrated land use planning.

6. There were consensus built in this workshop to explore the use of forest goods and services other than production of timber. It is strongly recommended that all timber company not only utilizing timber but also non timber forest products and environmental services. Government policy in favor of this issue is expected.

7. NGO's, International institutions, research institutions and academia are expected to facilitate the communication among stakeholders, in particular timber companies in the implementation of RIL and preparation towards SFM certification.

8. To support the recommendation no. 7 , it is suggested that partnership building and network to be developed. 


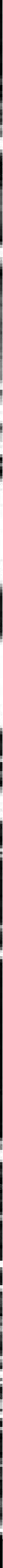


Sambutan Pembukaan 

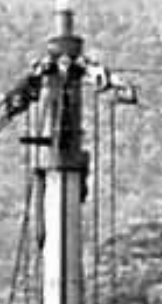

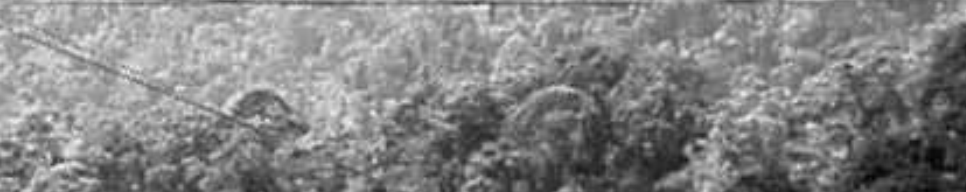




\title{
Sambutan Ketua Penyelenggara
}

\author{
Petrus Gunarso
}

Koordinator Malinau Research Forest-CIFOR

Selamat pagi dan salam sejahtera bagi kita semua,

Yth. Bapak Direktur Jenderal Bina Produksi Kehutanan atau yang Mewakili

Yth. Teman-teman di CIFOR, Tropenbos dan WWF Indonesia

Yth. Para Anggota APHI/KKS dan undangan lainnya yang berbahagia

Puji syukur bahwa kita dapat bertemu di tempat yang berbahagia ini untuk mendiskusikan bersama berbagai hal terkait pengelolaan hutan lestari melalui sertifikasi dan pembalakan berdampak rendah atau umum dikenal Reduced Impact Logging (RIL).

Pertemuan kali ini merupakan momen yang sangat tepat untuk mendiskusikan tata pengelolaan hutan yang baik. Beberapa minggu yang lalu, stasiun penelitian CIFOR di Malinau terkena banjir bandang, padahal lokasinya di daerah berhutan. Fakta ini menunjukkan bahwa kondisi hutan kita sudah sangat kritis dan mengkhawatirkan akibat salah urus. Dampaknya bisa dilihat dengan fenomena semakin meningkatnya bencana ekologis dimana-mana.

Temuan di wilayah Provinsi Kalimantan Timur (Kaltim) menunjukkan bahwa penanganan kasus kebakaran hutan di Indonesia melibatkan 32 instansi yang masingmasing mempunyai bagian tugas yang berbeda. Namun dalam pelaksanaannya instansi-instansi tersebut kurang sinergis, padahal dalam penanganan kebakaran hutan diperlukan kerjasama yang luas antar instansi. Dalam konteks kegiatan menuju tata kelola hutan yang baik, juga diperlukan keterpaduan antara para pihak yang berkepentingan sehingga tujuan tata kelola hutan merupakan tujuan bersama yang harus diwujudkan secara bersama-sama serta menjadi tanggung jawab secara kolektif pula. Pertemuan kali ini dimaksudkan untuk membangun kemitraan (partnership) terutama antara pemerintah, sektor swasta, akademisi, masyarakat dan para pihak lainnya.

Melalui program Forest Partnership, tiga lembaga internasional yaitu Tropenbos International Indonesia Program, WWF dan CIFOR saat ini sedang menginisiasi kemitraan antar para pihak dalam pengelolaan hutan lestari. Salah satu bagian penting dalam kerangka tersebut adalah pertemuan kali ini yang akan mendiskusikan 
banyak hal tentang sertifikasi dan RIL sebagai upaya untuk menerapkan prinsipprinsip praktek kehutanan terbaik (best forest practices). Dengan komunikasi tiga lembaga dan Departemen Kehutanan (Dephut) serta International Tropical Timber Organization (ITTO) sebagai salah satu penyandang dana. Kombinasi antar lembaga ini diharapkan bisa lebih bagus dalam implementasi. Maksud dari pertemuan kali ini adalah untuk bermitra, bekerja sama dan saling melengkapi, serta ada beberapa teknik menuju sertifikasi yang akan didiskusikan. Juga ada RIL atau umum dikenal sebagai pembalakan berdampak rendah yang merupakan inovasi teknis dalam pengelolaan hutan alam produksi.

Penghargaan dan terima kasih disampaikan kepada berbagai pihak yang telah turut mendukung dan mensukseskan kegiatan ini, terutama kepada Bapak Rusdi Manaf selaku Plt Kepala Dinas Kehutanan Provinsi Kaltim yang telah hadir di tengahtengah kesibukannya sekaligus untuk membuka acara. Juga kepada para panelis, undangan dan pihak-pihak lain yang membantu penyelenggaraan kegiatan ini.

Demikian, dan terima kasih. 


\title{
Sambutan Kepala Dinas Kehutanan Provinsi Kalimantan Timur
}

\author{
Rusdi Manaf \\ Pelaksana Harian Kepala Dinas Kehutanan Provinsi Kalimantan Timur
}

Assalamu 'Alaikum Wr. Wb.

Selamat pagi dan salam sejahtera bagi kita semua,

Yth. Bapak Direktur Jenderal Bina Produksi Kehutanan atau yang mewakili

Yth. Perwakilan CIFOR, Tropenbos dan WWF Indonesia

Yth. Para Anggota APHI/KKS

Lembaga Swadaya Masyarakat serta peserta lokakarya yang saya hormati

Pertama-tama marilah kita panjatkan puji dan syukur kehadirat Allah Yang Maha Esa atas segala rahmat dan karunia-Nya sehingga pada hari ini kita semua dapat berkumpul disini dalam keadaan sehat wal afiat.

Hadirin yang saya hormati,

Acara pada hari ini sangatlah penting, karena itu kami mengucapkan terima kasih kepada panitia yang melaksanakan acara ini.

Kalimantan Timur (Kaltim) dengan luas kawasan hutan \pm 14 juta hektar (ha) mengalami degradasi yang ikut memberikan andil yang besar dalam kerusakan hutan di Indonesia. Diperkirakan degradasi hutan di Kaltim seluas $\pm 300.000-500.000$ ha per tahunnya yang mengakibatkan penambahan luasan lahan kritis. Berdasarkan data dari BPDAS Mahakam Berau sampai dengan tahun 2004 luas lahan kritis telah mencapai 6 juta ha baik di luar maupun dalam kawasan hutan.

Hadirin yang saya hormati,

Sumber permasalahan proses degradasi hutan khususnya di Kaltim seperti disampaikan di atas antara lain adalah:

- Kurang dan rendahnya komitmen pengusahaan hutan di masa lalu

- Adanya perubahan peruntukan kawasan hutan yang kurang merujuk kepada perundang-undangan yang berlaku.

- Pemanfaatan SDH pada masa euphoria otonomi daerah yang hanya mengejar peningkatan PAD

- Illegal logging 
- Kebakaran Hutan

- Perambahan hutan

- Kepastian kawasan hutan masih yang masih belum terwujud

- Dan lain-lainnya

Apabila dilihat dari sisi ekologi kita mengalami kerugian yang lebih besar lagi akibat dari permasalahan tersebut di atas

Disamping itu, di kawasan hutan juga terjadi pencurian kayu dan perambahan kawasan konservasi antara lain seperti Taman Nasional Kutai, juga munculnya keinginan enclave dari Pemerintah Daerah terhadap kawasan tersebut sehingga pengelolaannya tidak dapat berjalan secara optimal.

Hadirin yang saya hormati,

Sekarang mulai muncul modus baru yang mengancam kawasan-kawasan hutan negara, antara lain dengan adanya pengakuan lahan/areal oleh masyarakat setempat sebagai hutan adat, pemberian raja dan lain-lain. Penggunaan di luar bidang kehutanan juga harus kita waspadai, misalnya pertambangan batu bara, karena dampaknya akan mendorong masyarakat akan ikut merambah kawasan hutan hanya untuk mengharapkan ganti rugi.

Hadirin sekalian,

Sejalan dengan kebijakan Departemen Kehutanan, Dinas Kehutanan Provinsi Kalimantan Timur dengan visi "Terwujudnya pengelolaan hutan secara lestari berasaskan manfaat maksimal berpola pada pemberdayaan dan keberpihakan kepada rakyat", maka dengan visi tersebut antara lain dijabarkan dalam beberapa hal sebagai berikut: 1) Dengan langkah aksi seperti ikut menjamin keberadaan hutan; 2) Mengoptimalkan manfaat hutan; serta 3) Upaya perlindungan dan konservasi alam di kawasan suaka alam dan kawasan pelestarian alam.

Selanjutnya pemerintah provinsi sangat mendukung program dan upaya mewujudkan tata kelola hutan yang baik guna menuju pengelolaan hutan lestari dengan pola kemitraan (partnership) antara pemerintah, swasta dan masyarakat. Dengan dibangunnya kemitraan tersebut, diharapkan masing-masing pihak dapat berperan dalam upaya mewujudkan pengelolaan hutan secara lestari. Kemitraan yang perlu dibina juga adalah antara pemerintah pusat, provinsi dan kabupaten/kota jangan sampai masing-masing berjalan sendiri-sendiri.

Hadirin sekalian,

Peraturan yang jelas dan menguntungkan bagi semua pihak akan mendorong pengusaha untuk menerapkan prinsip-prinsip praktek kehutanan yang terbaik (best forest practices) yang berdampak positif bagi masyarakat lokal. Pemerintah Provinsi Kaltim sangat mendukung program tata kelola hutan yang lebih baik melalui program kemitraan ini. Pengelola hutan sudah semestinya menerapkan prinsip-prinsip praktek kehutanan yang terbaik terutama yang akan mendapat sertifikasi melalui dukungan beberapa pihak termasuk CIFOR dan WWF.

Ada isu mengenai pembukaan sejuta hektar untuk perkebunan kelapa sawit di perbatasan Kaltim, dimana WWF dan lainnya sudah konfirmasi tentang rencana ini. Masalah-masalah di perbatasan bisa menjadi acuan, termasuk kasus di Kalimantan 
Barat (Kalbar) yang saat ini kritis. Komitmen pemerintah provinsi adalah bahwa Taman Nasional Kayan Mentarang (TNKM) tetap dipertahankan, tetapi beberapa hal terkait dengan konsep dan pengkajian perlu dikritisi secara obyektif.

Saat kunjungan di Kaltim, Menteri Negara Lingkungan Hidup mengemukakan penolakan pembukaan sawit di perbatasan. Secara umum masalah yang dilihat hanya secara makro, sementara di tingkat mikro belum banyak dilihat. Masyarakat di pedalaman juga berkeinginan untuk maju seperti di daerah pesisir. Sekitar 2,7 juta penduduk di Kaltim saat ini terkonsentrasi di pesisir. Oleh karena itu pemerataan penyebaran penduduk melalui pembangunan di wilayah perbatasan perlu dipertimbangkan.

Salah satu teknik pengelolaan hutan yang baik adalah teknik pembalakan hutan yang berdampak rendah (Reduced Impact Logging-RIL), karena sistem ini menekankan penerapan seminimal mungkin kerusakan terhadap tegakan tinggal (residual stand) kerusakan tanah, air dan hidupan liar, dan di lain pihak perusahaan akan mendapatkan keuntungan yang optimum, sehingga akan mendorong dan mendukung perusahaan tersebut menjadi Green Company yang siap untuk mendapatkan sertifikat hutan lestari.

Dilaksanakannya lokakarya selama dua hari ini bertujuan:

1. Mengidentifikasi sejauh mana penerapan best forest practices, misalnya apakah RIL yang dilaksanakan oleh sektor swasta kehutanan ada mengalami hambatan, apa saja kendalanya baik teknis maupun kebijakan yang dihadapi, serta apa insentif yang didapat dalam penerapannya.

2. Mendukung sertifikasi sebagai suatu cara untuk menuju tata kelola hutan yang baik dan pengelolaan hutan lestari, serta memperkuat jaringan antara pemerintah, swasta dan masyarakat mengenai sertifikasi.

3. Mempelajari praktek sertifikasi yang sedang berjalan, mengidentifikasi insentif dan disinsentif dari sertifikasi bagi perusahaan, serta mencari masukan langkahlangkah kedepan yang harus ditempuh.

4. Untuk mengetahui panduan dan penilaian apa saja dalam konservasi keanekaragaman hayati yang cocok diterapkan dalam areal kerja kehutanan.

Pertemuan yang digagas oleh tiga mitra ini diharapkan dalam dua hari ini bisa menghasilkan input yang baik, terutama untuk kebangkitan kembali kehutanan di Kaltim.

Hadirin sekalian,

Dengan memahami berbagai pedoman dan teknik tersebut di atas, maka kekhawatiran akan segera berakhirnya pengusahaan hutan di Kaltim dapat dihindari. Apalagi dengan kehadiran berbagai lembaga yang bekerjasama dengan tujuan yang sama untuk melestarikan hutan di Kaltim, kita akan menatap masa depan yang optimis. Beberapa lembaga yang masuk di Kaltim, diantaranya Heart of Borneo (HOB), Borneo Tropical Rainforest Foundation (BTRF), dan lain-lain, diharapkan berkoordinasi dengan Pemerintah Provinsi. Saat ini yang bertindak sebagai pelindung untuk hal-hal seperti ini adalah Wakil Gubernur Bapak Yurnalis Ngayoh dan Ibu Lina Laden Mering. 
Demikian sedikit sambutan kami dan mohon maaf apabila terdapat kekeliruan dan kekurangan, serta dengan mengucap Bismillaahirrahmaanirrahiim, lokakarya pada hari ini secara resmi saya buka.

Terima kasih, Wabillahi Taufik Walhidayah Wassalamu 'Alaikum Wr, Wb.

Balikpapan, 21 Juni 2006

Plt. Kepala Dinas Kehutanan

Provinsi Kalimantan Timur,

Ir. H. Rusdi Manaf,M.Si.

NIP. 550006920 


\title{
Sambutan Dirjen BPK Departemen Kehutanan
}

\author{
Listya Kusumawardani \\ Direktur Penyiapan Pengusahaan Hutan Produksi, Departemen Kehutanan
}

Assalamu'alaikum Wr. Wb.

Seperti yang telah dikatakan oleh Kepala Dinas Kehutanan, Kalimantan Timur merupakan kawasan target bagi para penanam modal atau investor khususnya Hutan Tanaman Industri (HTI) selain Provinsi Kalimantan Barat, Jambi dan Riau. Kaltim masih dipandang sebagai areal yang atraktif, di sini juga tercatat sampai bulan Maret ada 70 Izin Usaha Pemanfaatan Hasil Hutan Kayu (IUPHHK) alam, dari 70 ijin itu sampai Maret ada 46 yang sudah menyelesaikan Rencana Karya Lima Tahunan (RKL)-nya.

Jika kita bicara tentang sertifikasi, tentunya kita akan bicara dari mulai awal sejak penerbitan ijin sampai hasil itu bisa keluar. Soal penerbitan ijin, pada saat ini sebagaimana di provinsi yang lain ada dua ijin untuk pengelolaan hutan alam produksi khususnya penerbitan di awal era desentralisasi. Ada ijin IUPHHK yang dikeluarkan oleh Menteri Kehutanan dan satu lagi adalah ijin IUPHHK yang dikeluarkan oleh Bupati dan Gubernur melalui Surat Keputusan (SK) Menteri Kehutanan 05.1/ Kpts-II/2000. Sejak dikeluarkannya SK tersebut banyak sekali bermunculan ijinijin yang dikeluarkan oleh Bupati dan Gubernur termasuk juga di Kaltim. Dalam perjalanannya kemudian pemerintah pusat mengidentifikasi adanya masalah-masalah setelah dikeluarkannya ijin-ijin tersebut, maka kemudian kewenangan tersebut ditarik kembali ke pusat tahun 2002, dengan keluarnya Peraturan Pemerintah (PP) No. 34 Tahun 2002. Semenjak itu maka kewenangan pemberian ijin IUPHHK tidak lagi diberikan kepada daerah dan perijinan IUPHHK dikembalikan kepada pemerintah pusat dalam hal ini Departemen Kehutanan melalui Menteri Kehutanan.

Terhadap ijin-ijin yang sudah diterbitkan Bupati dan Gubernur tersebut akan dilakukan verifikasi. Nantinya verifikasi yang dilakukan oleh Departemen Kehutanan bermacam-macam, ada verifikasi ijin yang dari awal diterbitkannya ijin IUPHHK sampai ijin permohonan, juga ada verifikasi ijin-ijin industri pengolahan hasil hutan kayu dan lain-lain. Biasanya kalau berhadapan dengan publik yang berbeda 
dari dinas kehutanan, topiknya akan menanyakan masalah verifikasi ini. Bukti dan fakta yang dihadapi ialah proses verifikasi menimbulkan birokrasi baru yang mengakibatkan keterlambatan. Sehingga tidak seperti yang diharapkan dan apa yang menjadi ketetapan Presiden RI Susilo Bambang Yudhoyono bahwa perijinan itu harus disesuaikan dengan jangka waktu 30 hari.

Dengan adanya verifikasi itu kita memiliki data-data lengkap di beberapa tempat. Dari ijin-ijin Bupati atau Gubernur yang dikeluarkan pada umumnya kita tidak bisa mengarah atau memberikan pembaharuan ijin atau menyetujui ijin tersebut disebabkan karena adanya rumor proses verifikasi ini. Yang menjadi prioritas adalah bagaimana kelanjutannya? Bagaimana komitmen pemegang ijin? Apakah pemegang ijin itu masih berkehendak? Jika berkehendak dan masih memiliki komitmen, apakah kembali lagi pada pemiliknya? Oleh karena itu maka pemerintah perlu melakukan pengaturan terhadap IUPHHK kecil ini terutama terhadap para pihak yang telah menyatakan kesediaan dan memberikan komitmen.

Dulu pernah dilakukan identifikasi terhadap areal-areal baru yang akan ditawarkan pada investor, prosesnya berlangsung cukup lama karena tidak ada keharmonisan pusat dan daerah. Misalnya saat melakukan identifikasi areal melalui daerah ke dinas kehutanannya. Pada waktu kita datang, kita tidak bisa mengetahui bahwa areal itu clear dan clean. Selain itu bukan berarti areal tersebut juga bebas manusia, tetapi yang terpenting kita sudah mengetahui kondisi-kondisi di wilayah itu. Pada tahun ini, mungkin akhir bulan ini kita akan melakukan lelang terbuka terhadap areal IUPHHK dan HTI, termasuk ada beberapa lokasi di Kaltim.

Dalam hal sertifikasi, di Departemen Kehutanan kita melakukan penilaian terhadap IUPHHK dan HTI juga di beberapa Ijin Pemanfaatan Kayu (IPK) Hutan Tanaman melakukan audit kinerja yang dilakukan oleh LPI. Pada saat ini dari tahun 2002 sampai sekarang kita sudah mencapai 127 persemaiannya di Lembaga Penilai Independen (LPI), kalau untuk penanamannya sekitar 100 juta, ini adalah monitoring kewajiban terhadap pelaksanaannya. Pada penilaian pertama dilakukan dan dibiayai oleh pemerintah tapi yang kedua dan seterusnya dilakukan dan dibiayai oleh pemegang ijin. Sekarang ini penilaian audit kinerja itu lebih merupakan pembinaan. Kalau dulu jika ijin IUPHHK hasilnya buruk mungkin akan berakibat pada pencabutan ijin, sekarang terhadap hasil yang buruk kita akan memperketat pembinaan. Tetapi jika bagi areal-areal yang mungkin akan diperpanjang dan yang akan memperoleh ijin baru dengan kegiatan audit kita lihat satu persatu, jadinya buruk itu bukan satu alasan untuk melakukan pencabutan. Pemerintah juga melihat pengalaman yang di masa lalu, mencabut ijin itu bukan menyelesaikan masalah malah menimbulkan masalah baru, artinya kita kehilangan areal-areal potensial menjadi areal tidak terkelola dan kita juga tidak segera memperoleh pemegang ijin yang baru. Terhadap tipe-tipe atau jenis ijin ada yang baru dari pemerintah, yaitu ijin usaha pemanfaatan hasil hutan kayu tapi dengan pemuliaan ekosistem yang kira-kira bisa diketahui oleh para pihak yang membina.

Dengan acara-acara seperti ini tentunya kita menghendaki adanya harmonisasi data dan informasi. Selama ini data terfokus kepada kondisi fisik kawasan tanpa ada informasi mengenai kondisi sosial ekonomi masyarakat. Di sini kita bisa melakukan harmonisasi data, sharing data antara pusat dan daerah. Sekarang masih melalui lelang 
di PP 34, tetapi jika sudah berubah PP 34 itu akan kembali menjadi permohonan, kita juga harus berhati-hati dengan permohonan ini agar jangan sampai lebih berbentuk informasi yang menjadi card mobile, karena dengan lelang itu kita terbuka pada semua pihak saling bertanya yang mana menjadi kekurangannya. Walaupun dengan lelang itu ada hal-hal yang kira-kira perlu diperbaiki bagaimana kita memberikan peluang sama terhadap yang kecil sehingga tidak pada yang besar saja.

Dalam hal sertifikasi mungkin kepada para pihak disini yang hadir, bagaimana kita menerapkan sistem sertifikasi yang sesuai dengan kondisi di Indonesia, jadi bagaimana kita mendorong dan menarik perusahaan ini untuk bisa menuju lebih baik. Kepada perusahaan-perusahaan yang telah mempunyai sertifikasi, bentuk reward-nya terutama pada saat pengurusan Rencana Karya Tahunan (RKT). Berkas yang seharusnya diserahkan kepada pemerintah pusat karena semua penandatanganan dilakukan Jakarta, tidak perlu melalui proses yang lama. Contoh untuk kasus Aceh, reward dari pemerintah untuk daerah bencana, adalah dipermudahnya proses urusan RKT maupun urusan RKL oleh Dephut. Jika sudah sertifikasi apakah perusahaan itu bisa ekstensif menambah data petak tebangannya? Jika sudah diberikan ijin kepercayaan melalui sertifikasi, jangan sampai kepercayaan itu disalahgunakan, karena tentunya nanti sertifikasi itu akan dihapus dari pemerintah pusat dan nanti akan ditindaklanjuti.

Dan saya ingatkan kembali bahwa di hutan-hutan produksi seakan-akan dalam pengelolaannya tidak memahami dan tidak memperhatikan konservasi biodiversity, High Conservation Value Forest (HCVF) dan lain-lain. Padahal tahun 1990 sudah ada edaran dari Bapak Jamaludin bahwa ada $500 \mathrm{Ha}$ jangan ditebang apabila batasnya belum jelas. Artinya sudah ada aturan mengenai kawasan lindung dan konservasi di hutan produksi. Pemberian sertifikasi juga ada perbedaan antara ijin yang dikeluarkan pemerintah pusat dengan pemerintah daerah. LPI perlu transparan karena dilakukan oleh pihak ketiga yang independen sebagai masukan bagi pemerintah pusat dalam menentukan keberlanjutan pengelolaan hutan. Dalam pembuatan sertifikasi akan dilihat apakah perusahaan tersebut overlap terhadap perusahaan yang lain atau tidak.

HPHKM juga akan dievaluasi dan verifikasi, khususnya mengenai kepastian kawasan (overlapping). Pemerintah pusat melalui departemen kehutanan akan mengeluarkan SK tentang surat dan keterangan asal usul kayu, ini mirip dengan Surat Keterangan Sah Hasil Hutan (SKSHH) tetapi dikeluarkan oleh Kepala Desa, dan ini mengundang reaksi kepada Kepala Dinas Kehutanan yang tidak setuju karena bagaimana dengan monitoringnya sehingga draf SK yang sudah siap akhirnya ditunda untuk dikeluarkan. Kebijakan pengaturan ini dikeluarkan agar tidak terjadi penyalahgunaan wewenang dalam penangkapan kayu oleh aparat hukum. Dan juga memberikan pembekalan pada aparat penegak hukum mengenai kegunaan kayu tersebut.

Demikian beberapa hal yang mungkin bisa disampaikan pada kesempatan yang terbatas di acara ini. Semoga bisa menjadi perhatian dan masukan bagi proses diskusi lokakarya tentang sertifikasi dan pengelolaan hutan lestari ini.

Sekian, dan terima kasih. 


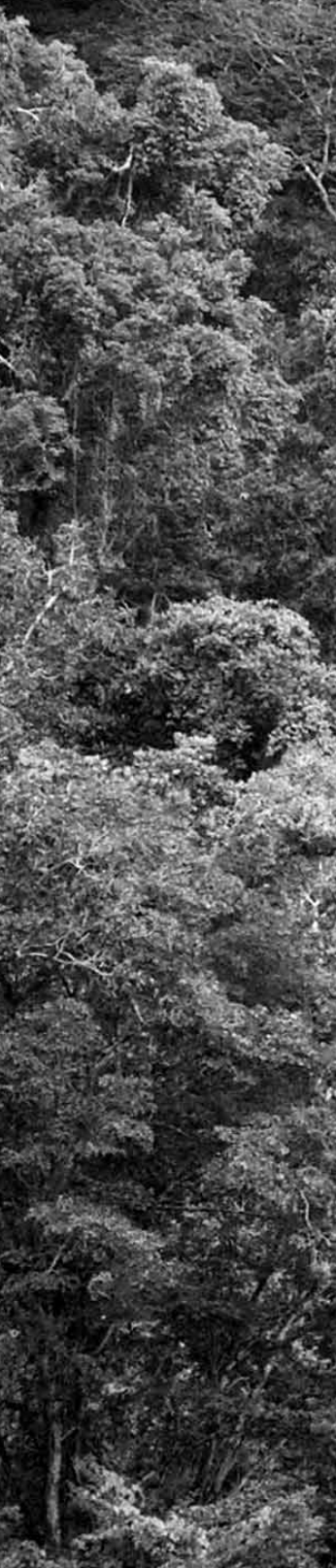

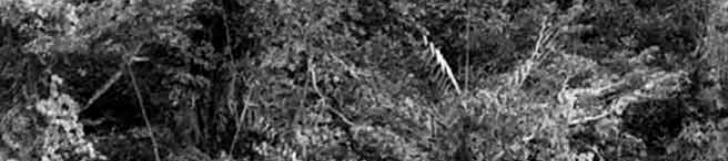

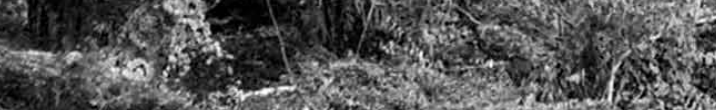

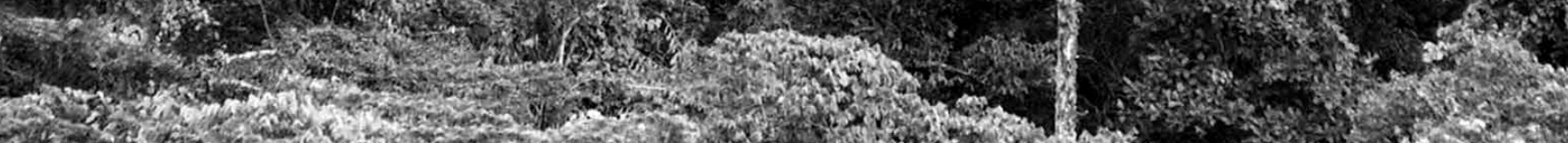

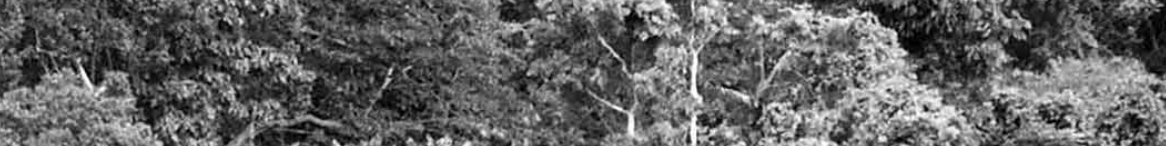
1.

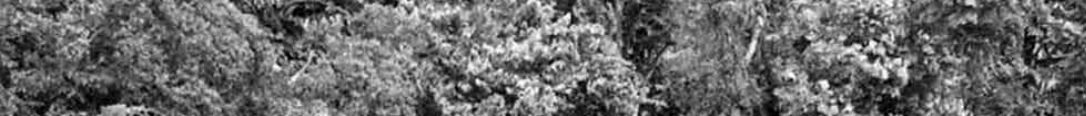

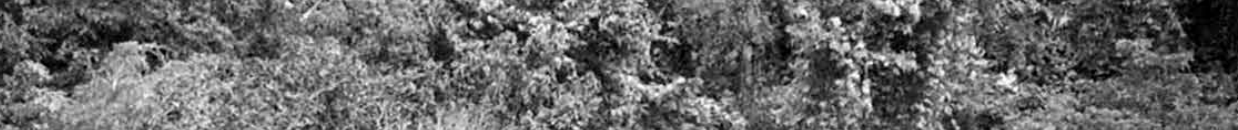

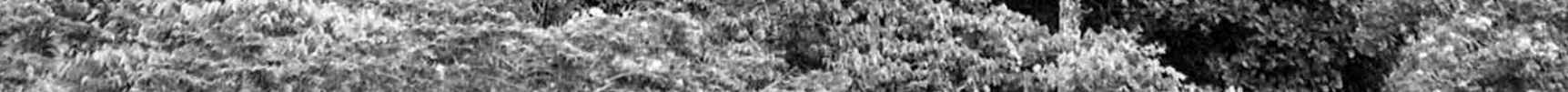

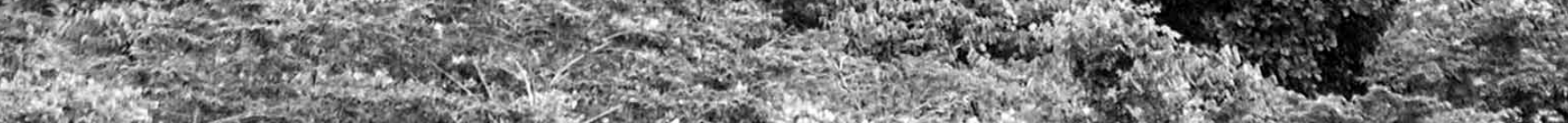

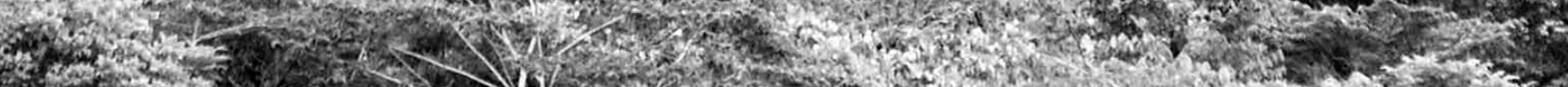

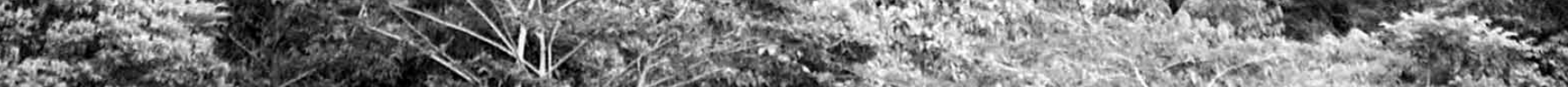

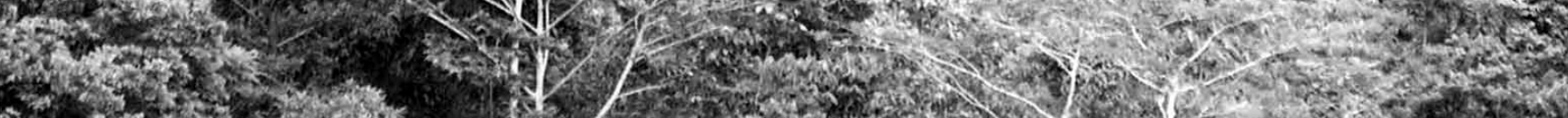
Bentang alam hutan tropis di Kalimantan Timur (Douglas Sheil) 


\section{Kerangka Acuan}

\section{Latar Belakang}

Pengelolaan Hutan Lestari sangat tergantung pada rentang dan kualitas kebijakan pemungkin (enabling policies) sebagaimana halnya kondisi hukum dan kelembagaan yang menjadi landasan bagi tata kelola hutan yang baik (Good Forest Governance-GFG). Penting untuk digarisbawahi bahwa seringkali permasalahan kehutanan (deforestasi dan degradasi hutan) terjadi sebagai akibat dari permasalahan di luar kehutanan atau lintas sektoral, dengan demikian sangat diperlukan pemahaman menyeluruh terhadap kebijakan-kebijakan yang mengakibatkan timbulnya permasalahan tersebut.

Hubungan kemitraan (partnership) antara pemerintah, sektor swasta, dan masyarakat merupakan faktor penting dalam menuju tata kelola hutan yang baik. Pemerintah perlu menetapkan perannya menuju pelaksanaan birokrasi/administrasi yang efisien dan alokasi tata guna lahan yang lebih baik. Aspek hukum dan peraturan telah tersedia dengan baik dan iklim usaha yang mendukung bagi pihak swasta diharapkan dapat mendorong pihak swasta untuk menerapkan prinsip-prinsip praktek kehutanan terbaik (best forest practices) dengan cara yang juga memberikan manfaat bagi masyarakat lokal. Aktivitas-aktivitas tersebut menjawab kebutuhan untuk membangun kemitraan antara berbagai pihak yang aktif, yang mengaitkan peningkatan tata kelola hutan di Kalimantan dengan pasar internasional.

Berkaitan dengan hal tersebut, usaha-usaha telah dilakukan oleh berbagai pihak termasuk program kehutanan dari berbagai organisasi internasional. Sebagian dari program tersebut juga telah melakukan perubahan/adaptasi pendekatannya untuk menyesuaikan dengan era transisi desentralisasi. Usaha-usaha tersebut juga ditujukan untuk memperbaiki prakondisi terciptanya praktek pengelolaan hutan yang baik melalui sertifikasi pengelolaan hutan lestari, konservasi keanekaragaman hayati, pengurangan laju kerusakan tegakan melalui pembalakan hutan terkendali (Reduced Impact Logging - RIL), dan pengurangan konflik sosial dalam pengelolaan hutan melalui mekanisme resolusi konflik.

Penerapan RIL bertujuan untuk menekan seminimal mungkin kerusakan akibat pembalakan terhadap tegakan tinggal (residual stand) serta kerusakan tanah, air serta hidupan liar (wildlife), di lain pihak perusahaan tetap meraih keuntungan yang optimum. Hal ini akan mendukung perusahaan tersebut menjadi green company yang siap untuk mendapatkan sertifikat hutan lestari. Dalam penilaian sertifikasi, baik itu standar Forest Stewardship Council (FSC) maupun Lembaga Ekolabeling Indonesia (LEI) kaidah-kaidah di atas sangat dipertimbangkan dalam bobot penilaian mereka. 


\section{Tujuan}

Lokakarya ini bertujuan untuk:

1. Mengidentifikasi sejauh mana penerapan best forest practices seperti RIL dilaksanakan oleh sektor swasta kehutanan, apa saja kendala teknis dan kebijakan yang dihadapi, serta insentif apa yang didapat dalam penerapannya.

2. Mendukung sertifikasi sebagai suatu cara untuk menuju tata kelola hutan yang baik dan pengelolaan hutan lestari, dan juga untuk memperkuat jaringan antara pemerintah, sektor swasta dan masyarakat mengenai sertifikasi

3. Mempelajari praktek sertifikasi yang sedang berjalan, mengidentifikasi insentif dan disinsentif dari sertifikasi bagi perusahaan kayu serta mencari persetujuan tentang langkah-langkah kedepan yang harus ditempuh

4. Mengetahui panduan dalam penilaian konservasi keanekaragaman hayati yang cocok diterapkan dalam areal kerja kehutanan.

\section{Keluaran}

Keluaran yang diharapkan dalam lokakarya ini adalah:

1. Peserta dapat mengidentifikasi kendala, insentif dalam penerapan best forest practices seperti RIL, serta apa saja yang diperlukan dalam proses pengadopsiannya melalui pembelajaran dari pelaku usaha kehutanan

2. Meningkatnya pemahaman praktek sertifikasi serta tantangannya dalam pasar global yang penuh gejolak

3. Meningkatnya kemampuan dalam penilaian konservasi keanekaragaman hayati

4. Meningkatnya pemahaman tentang tata kelola hutan yang baik

\section{Skema Alur Lokakarya}

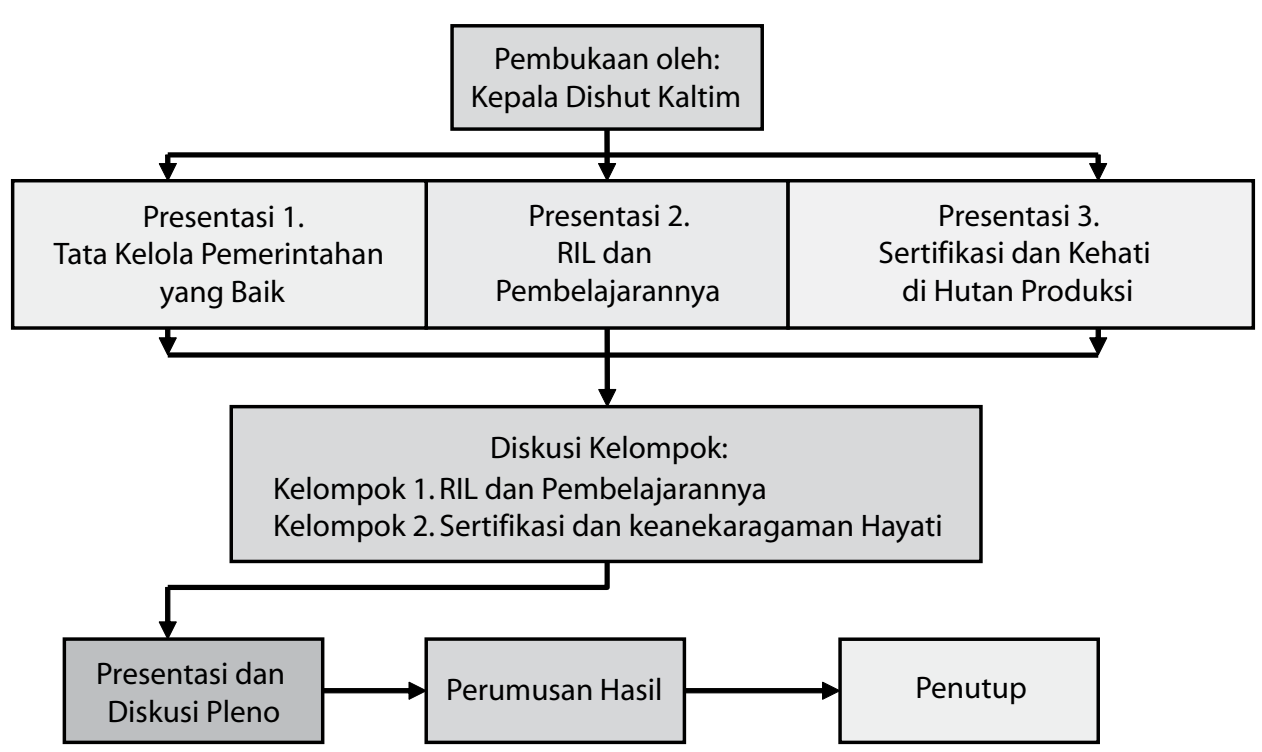


Presentasi 


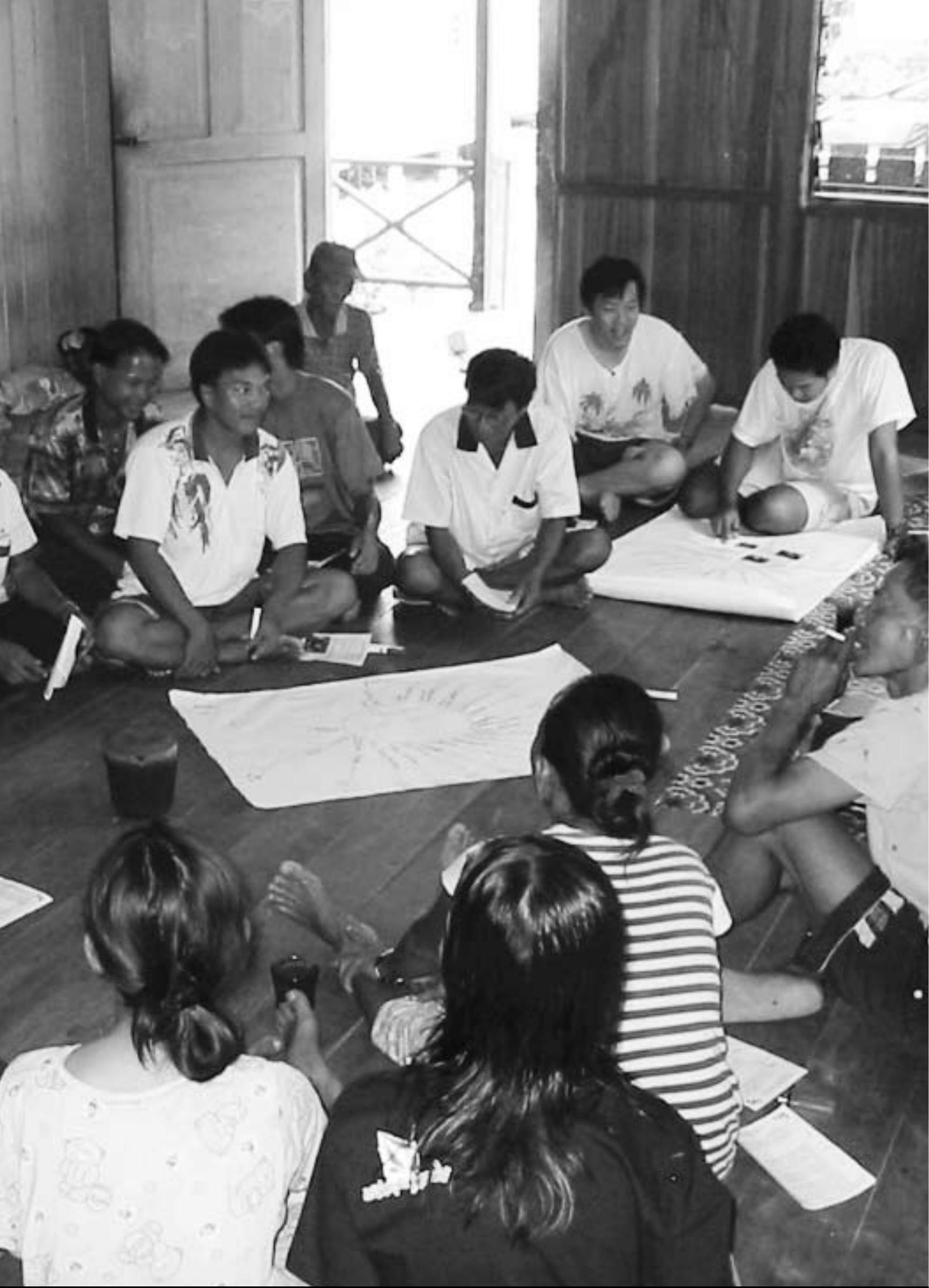

\section{Keputusan harus dimusyawarahkan bersama dalam mengelola sumberdaya alam (Douglas Sheil)}




\section{Materi}

Materi presentasi dalam Lokakarya secara umum dibagi 3 (tiga) sesi yaitu: 1) Sesi Satu: Tata kelola pemerintahan yang baik (good corporate governance); 2) Sesi Dua: RIL dan pembelajarannya; dan 3) Sesi Tiga: Sertifikasi dan keanekaragaman hayati pada hutan produksi. 


\section{Presentasi Sesi 1. \\ Tata Kelola Pemerintahan yang Baik (Good Corporate Governance)}

- Materi mengenai tata kelola pemerintahan yang baik (good corporate governance) yang disajikan mencakup sebagian dari hubungan tata kelola pemerintahan yang baik dengan pengelolaan hutan lestari melalui pengalaman, pembelajaran dan temuan yang selama ini diperoleh dalam sektor kehutanan.

- Materi dalam sesi ini disampaikan oleh narasumber dari lembaga internasional seperti Tropenbos International Indonesia Program, CIFOR dan Smartwood serta lembaga akademik yaitu Kelompok Kerja Sertifikasi Hutan (KKS) Universitas Mulawarman (Unmul). Topik dan presenter dari masing-masing narasumber tersebut yaitu:

1). Forest Partnership Program: Menuju Tata Kelola Hutan yang Berkelanjutan oleh Alfan Subekti (Tropenbos International/TBI)

2). Peran Pelaku Usaha Kehutanan Menuju Tata Kelola Hutan yang Baik (Sebuah Pembelajaran) oleh Agung Prasetyo (CIFOR)

3). Peranan Kelompok Kerja Sertifikasi dalam Mewujudkan Tata Kelola Hutan yang Baik oleh Prof. Soeyitno Soedirman (Unmul)

4). Tantangan dan Kesempatan Sertifikasi dalam Pasar Global oleh Mr. Loy Jones (Smartwood)

- Melalui presentasi dan diskusi antara narasumber dengan para peserta lokakarya diharapkan akan memberikan berbagai perspektif tentang permasalahan kehutanan (antara lain deforestasi dan degradasi hutan) yang seringkali terjadi sebagai akibat dari permasalahan di luar kehutanan atau lintas sektoral. Selain itu akan diperoleh beberapa pemahaman dan pembelajaran terhadap kebijakankebijakan yang mengakibatkan timbulnya permasalahan tersebut.

- $\quad$ Presentasi dan proses diskusi (tanya jawab) difasilitasi oleh Prof. Mustofa Agung Sardjono dari Center for Social Forestry (CSF), Unmul. Proses dan diskusinya sebagai berikut: 


\section{Presentasi 1. Alfan Subekti (TBI)}

Presentasi diawali dengan penjelasan mengenai Forest Partnership yang merupakan kolaborasi tiga lembaga (WWF, TBI, CIFOR) beserta kegiatan yang telah akan dilakukan serta tiga lokasi kabupaten di Kalimantan (Kapuas Hulu, Pasir, dan Malinau) yang sedang diinisiasi sebagai kabupaten konservasi.

Selanjutnya diuraikan materi presentasi dengan tema-tema sebagai berikut:

- Kondisi hutan di Kalimantan

- Tata kelola hutan yang baik

- $\quad$ Prinsip-prinsip Good Forest Governance (GFG)

- Elemen-elemen GFG

- Government vs. Governance

- Pentingnya Good Governance dan strategi perbaikannya

- Forest Partnership Program (Modul, Area, Lingkup kegiatan, dan Harapanharapan)

\section{Presentasi 2. Agung Prasetyo (CIFOR)}

Presentasi diawali dengan penjelasan mengenai gambaran umum mengenai materi yang akan dipresentasikan serta keterkaitan antara topik presentasi dengan tema lokakarya. Tema-tema presentasi yang disampaikan sebagai berikut:

- Typology Model of Governance: Libertarian, Corporatists, Communitarian, Static

- Good Governance (GG): GG sebagai manifesto politik baru, Bank Dunia, Masyarakat Uni Eropa, UNDP

- $\quad$ GFG

- Uraian Pyramid of Good Governance dan relevansi pada pelaku usaha kehutanan

- Fakta empiris pengusahaan hutan

- Prediksi prospek pekerja di sektor kehutanan

- Upaya para pihak menuju GFG

- Tools dan instrumen dalam mencapai GFG: sertifikasi Pengelolaan Hutan Produksi Lestari (PHPL), RIL, CSR, Pendekatan Tahapan ke PHPL, HCVF

- Forest Partnership Program: Good GovernancelArea Based Conservation, International and (domestic) Market Links, Forest Conversion (Land Use), Learning lesson, Peran Forest Partnership Program (WWF-TBI-CIFOR)

- Rekomendasi dan tindak lanjut

\section{Presentasi 3. Prof. Soeyitno Soedirman (KKS-Unmul)}

Sebagai pembuka presenter mengemukakan alasan topik dengan tema Eksistensi dan Peran KKS dalam PHPL sebagai Sebuah Renungan dan Harapan ke depan.

Presentasi diawali dengan penjelasan mengenai apa KKS dan perkembangannya dalam tahun-tahun terakhir serta pencapaiannya. Kemudian dilanjutkan dengan topik aspek ekonomi dalam PHPL serta sertifikasi dan pengelolaan hutan lestari, dan diakhiri dengan prinsip-prinsip tata kelola hutan yang baik dan keterhubungan antara aspek-aspek terkait. Secara detail uraian tema-tema presentasinya sebagai berikut:

- Keberadaan KKS: Latar belakang, legalitas, organisasi 
- Visi dan misi KKS

- Rencana dan realisasi program kerja KKS

- $\quad$ Sintesa hasil program kerja: Partisipasi IUPHHK-anggota, kondisi tingkat kesiapan, langkah-langkah mendesak

- Program pengembangan: Dasar pemikiran, kegiatan pengembangan

- Usulan KKS ke depan: Struktur dan usulan restrukturisasi organisasi

- Aspek ekonomi dalam PHPL: Taksiran riap volume

- Sertifikasi dan pengelolaan hutan lestari: Pengertian sertifikasi dan sertifikasi hutan, beberapa aspek dalam PHPL, prakondisi indikator, contoh, reformasi birokrasi

- $\quad$ Prinsip-prinsip pemerintahan yang baik (GG)

\section{Presentasi 4. Loy Jonnes (Smartwood)}

Presentasi menggunakan bahasa Inggris, dan diawali dengan penjelasan tentang apa Smartwood dan kegiatan-kegiatan yang telah dan sedang dilakukan khususnya di Indonesia.

Pokok-pokok dari tema materi presentasi yang disampaikan sebagai berikut:

- Rainforest Alliance Mission

- Collaborative Global Action

- 10 FSC Principles

- Challenges - Legal

- Challenges-Capacity

- The Structure of Certification

- What does certification assess?

- How is Certification Unique?

- Designing Better Business Practices Collaboratively

- Demand for FSC Lumber

- Benefits of Certification for Industry

- Success to Date: SmartWood

- Creating Opportunities for Change

\section{Panel Diskusi}

- Selesai presentasi keempat presenter, moderator membuka sesi diskusi dengan mempersilakan peserta untuk mengajukan beberapa pendapat baik pertanyaan, klarifikasi atau pengalaman lainnya.

- Mengingat keterbatasan waktu, moderator membatasi pertanyaan untuk lima orang peserta. Sebelum mengajukan pertanyaan atau pendapat moderator meminta penanya untuk menyebutkan nama dan asal institusi.

- Masing-masing penanya, pertanyaan dan tanggapan presenter adalah sebagai berikut: 


\section{Pertanyaan:}

\section{Gusti Hardiansyah (PT Alas Kusuma Group/PT SBK):}

- Kepada Agung Prasetyo: tipologi yang dikutip bersifat politik, ekonomi manifesto lain seperti agama, dimana letak tata kelola dalam tipologi tersebut

- Tata kelola yang baik ada pembagian peran

- Pertimbangan apa mengenai penurunan tenaga kerja di tahun 2005

- Loy Jones: Alas Kusuma merupakan satu perusahaan yang bekerjasama dengan Smartwood

\section{Sulistyo Siran (BPK):}

- Mempertahankan Sustainable Forest Management (SFM) tanpa sertifikasi pun mudah, yang penting setelah penebangan hutan harus dijaga dari illegal logging dan re-logging. Berdasarkan hasil studi yang sudah dilakukan, pada tahun ke8 setelah penebangan volume kembali seperti kondisi hutan alam selama bisa mereduksi gangguan.

- Sertifikasi di Kaltim cenderung tidak mengalami perkembangan dan sepertinya statis. Cara pandang dari stakeholder terhadap sertifikasi sebagai salah satu faktor yang membatasi kegiatan pengusahaan hutan sehingga sertifikasi dan SFM tidak terealisasi. Dalam konteks ini penting juga melihat kembali indikator output dan input. Selama input menjadi prioritas, maka SFM akan tercapai khususnya terhadap komitmen penganggaran yang cukup bagi terwujudnya SFM. Assessor seringkali melihat dari output, meski komitmen perusahaan tinggi dalam SFM selama masih terjadi masalah sosial dan illegal logging maka SFM (dianggap) tidak tercapai. Cara pandang seperti ini harus tercapai dalam satu titik temu. Apakah ada usaha-usaha untuk mencari titik temu ke arah yang lebih baik agar perusahaan yang sudah punyai potensi dan komitmen dapat eksis.

\section{Hasbilah (TFF):}

Sertifikasi pada akhirnya adalah secara bisnis, konservasi dan sosial juga menguntungkan. RIL sudah baik ketika sudah tercapai sertifikasi. Kendala-kendala adalah omong kosong karena semua data dan fakta menguntungkan. Apa yang perlu dikaji ulang mengenai pendidikan dasar, masih dalam proses pembelajaran, banyak IUPHHK yang belum tahu mengenai kriteria dan indikator ( $\mathrm{C}$ and I). Perlu pembelajaran, pengembangan dan mandatory.

\section{Azis (Dishutbun Pasir) :}

Secara khusus ditujukan untuk narasumber dari TBI (Alfan Subekti) dan CIFOR (Agung Prasetyo):

- Kerusakan hutan di Kalimantan Timur juga diakibatkan oleh tekanan peningkatan jumlah penduduk, serta pengelolaan hutan yang kurang baik. Yang tak kalah penting adalah perubahan status dan fungsi hutan serta moral dari pengelola.

- Bagaimana menyikapi pengelolaan hutan yang lestari di tingkat pemerintah kabupaten. 
- Pola hubungan partnership, intinya adalah masyarakat di samping pihak pemerintah. Mengingat semakin kompleksnya permasalahan, partnership juga harus dilakukan juga dengan penegak hukum, perlu dibangun persepsi yang sama mengenai SFM.

- Mengenai kebijakan pengembangan kelapa sawit, saat ini di Kabupaten Pasir sudah dikembangkan dengan areal seluas \pm 60.000 ha. Kebun sawit konon penyerap air sehingga menimbulkan kekeringan. Kenyataan yang sudah terjadi akibat konversi hutan menjadi perkebunan sawit menjadi pelajaran bersama bahwa kita harus berhati-hati terhadap pembangunan perkebunan kelapa sawit mengingat dampak negatif yang diakibatkan terhadap lingkungan sebagaimana terjadi di Kabupaten Pasir.

- Menyambut baik upaya CIFOR, beberapa tahun lalu CIFOR pernah bekerjasama dengan Pemkab Pasir dalam pengelolaan Hutan Lindung Gunung Lumut (HLGL), pertanyaannya adalah kenapa pengelolaan HLGL terhenti, bagaimana kelanjutannya, masyarakat sangat terbantu dengan adanya pemanfaatan Non Timber Forest Product (NTFP) khususnya mengenai budidaya rotan, yang diperlukan adalah bagaimana masyarakat mampu memasarkan (market linkage) terhadap kerajinan masyarakat tersebut.

- Dalam hal sertifikasi, setuju dengan Pak Sulistyo terlalu banyaknya persyaratan akan memberatkan IUPHHK.

- Dalam hal KKS, perlu sosialisasi ke kabupaten. Intinya mendukung dengan duduk bersama antara pemkab, IUPHHK sebagai jalan untuk menyelesaikan konflik dengan masyarakat.

- Khusus tata ruang, mendukung karena Rencana Tata Ruang Wilayah Kabupaten (RTRWK) adalah kunci. Adanya usulan perubahan dari Kawasan Budidaya Kehutanan (KBK) menjadi Kawasan Budidaya Non Kehutanan (KBNK) sesuai dengan usulan perubahan RTRW Provinsi, maka perlu dilakukan pengkajian yang komprehensif.

\section{Yosef Ruslim (TNC-Unmul):}

- Ancaman akibat revisi tata ruang, peran program forest partnership untuk mengeliminir ancaman tersebut.

- Dalam hal sertifikasi FSC, belum adanya premium price ini merupakan hambatan. Selama ini hanya pasar lokal, sementara pasar internasional belum ada.

\section{Tanggapan}

\section{Alfan Subekti (TBI):}

- Moral dan perilaku, intinya adalah bagaimana sertifikasi dibawa sampai level kabupaten. Forest Partnership Program (FPP) juga tidak hanya bekerjasama dengan pemerintah tetapi juga dengan perusahaan. Fokusnya ada di modul 1 dan modul 2 khusus untuk sertifikasi. Dari sisi pemerintah kabupaten, diperlukan penyegaran kembali agar dibangun kebijakan-kebijakan yang mendukung proses sertifikasi. 
- Modul 3, bagaimana upaya-upaya konversi hutan dengan memperhatikan konservasi, tool-nya adalah best management practices dan HCVF.

- FPP diminta tanggapannya terhadap rencana revisi Rencana Tata Ruang Wilayah Provinsi (RTRWP) dalam kapasitas untuk memberikan masukan. Fokus FPP dalam perencanaan tata ruang lebih ditekankan kepada pengembangan kapasitas sumberdaya manusia dengan membangun Forum GIS sebagaimana di kabupaten Pasir yang bertugas menyediakan spatial database dan mengelola data-data spasial.

\section{Agung Prasetyo (CIFOR):}

- Manifesto GG yang pada awalnya dilandasi oleh masalah norma dan agama kenapa mengerucut ke private sector. Private sector mendorong proses yang luar biasa dalam menuju GG. Hanya penggambaran dari 3 unsur yang berpengaruh terhadap pasar yaitu negara, masyarakat dan pasar.

- Proyeksi ketenagakerjaan, diskusi masih draft berdasarkan asumsi dan dibangun skenario, apabila kondisi kehutanan tidak mengalami perubahan, un-documented logging dan konversi meningkat. Tapi bagaimana kalau ada penanaman besarbesaran? Yang menjadi masalah adalah masa transisi antara habisnya hutan alam dan masa pemanenan hutan tanaman.

- Sertifikasi lambat, dilihat dari titik awal pelaksanaan IUPHHK di Indonesia, masa pembangunan sistem yang membutuhkan waktu, masalahnya tidak adanya insentif dan disinsentif. Standar rendah, yang berorientasi terhadap sertifikasi adalah perusahaan yang peduli bahwa bisnis kehutanan adalah bisnis jangka panjang.

- ACM di Pasir berhenti, adanya FPP merupakan jembatan atas proses yang terputus sehingga diharapkan TBI bisa melanjutkan.

\section{Soeyitno Soedirman:}

- Ada program awareness building (peningkatan kesadaran) agar bagaimana daerah bisa memfasilitasi proses ini. Banyak forum di Kaltim tapi tidak efektif seperti FKPHD, kelanjutannya tergantung komitmen dari penentu kebijakan yang sebagian besar belum ada.

- Sertifikasi adalah market driven, tahapan kehutanan di Indonesia cenderung lebih berorientasi pada hasil kayu. Proses ke depannya tidak adanya dukungan dari penentu kebijakan, dan cenderung tidak ada feedback dari para evaluator Dinas Kehutanan yang melakukan evaluasi. Kita lebih dahulu tahu masalah sosial dan konservasi dibandingkan dengan aspek lainnya.

- Masalah ke depan kehutanan adalah masalah RTRW, perlu duduk bersama untuk mengembangkan mengingat itu merupakan ancaman terutama alih fungsi kawasan di hutan produksi. 


\section{Presentasi Sesi 2. \\ Reduced Impact Logging (RIL) dan Pembelajarannya}

- Materi mengenai RIL dan pembelajarannya yang disajikan mencakup beberapa pengalaman dan temuan baik dari hasil studi maupun aplikasi implementasi langsung di lapangan oleh beberapa perusahaan.

- Materi dalam sesi ini disampaikan oleh narasumber dari lembaga internasional yang saat ini banyak melakukan kajian tentang RIL di Indonesia yaitu Tropical Forest Foundation (TFF) dan beberapa IUPHHK yang cukup sukses menerapkan RIL yaitu PT Sari Bumi Kusuma (Alas Kusuma Group) dan PT Sumalilndo Lestari Jaya (SLJ) II. Topik dan presenter dari masing-masing narasumber tersebut yaitu:

1). RIL, Hubungan dan Manfaatnya oleh Mr. Art Klassen dan Ir. Hasbillah (TFF)

2). Pembelajaran Silvikultur Intensif oleh PT. Sari Bumi Kusuma: Pendekatan RIL \& Pengayaan Tegakan di Areal Hutan Produksi Alam Bekas Tebangan oleh Gusti Hardiyansyah

3). Jalan Panjang Menuju Sertifikasi PHPL: Pembelajaran dari PT SLJ II oleh Boby Bayu

- Melalui presentasi dan diskusi antara narasumber dengan para peserta lokakarya diharapkan akan memberikan gambaran umum tentang berbagai kendala, hambatan dan peluang dalam implementasi RIL sebagai salah satu instrumen dalam pencapaian PHL. Dengan demikian akan diperoleh/terjadi proses pembelajaran, pertukaran pendapat dan pengalaman, serta memperoleh kita-kiat tertentu yang perlu dipertimbangkan dalam mengimplentasikan RIL. Selain itu akan diperoleh beberapa interaksi dan interrelasi antar para pihak dalam upaya penyempurnaan dan pengembangan RIL dalam kerangka pencapaian PHL.

- Presentasi dan proses diskusi (tanya jawab) difasilitasi oleh Hari Priyadi dari CIFOR Bogor. Proses moderasi dan diskusinya sebagai berikut:

\section{Presentasi 1. Art Klassen dan Hasbilah (TFF)}

Presentasi dilakukan secara bergantian, diawali oleh Art Klassen dengan menggunakan 
pengantar bahasa Inggris sesuai materi di power point, dan dilanjutkan oleh Hasbillah untuk menyimpulkan beberapa point-point penting dalam materi yang disampaikan dengan pengantar bahasa Indonesia.

Presentasi diawali dengan pengenalan sepintas tentang Tropical Forest Foundation (TFF) beserta kegiatan yang telah dan sedang dilakukan khususnya di Indonesia.

Selanjutnya presenter menguraikan materi presentasi dengan tema-tema sebagai berikut:

- TFF suatu Perkenalan: latar belakang, visi, ruang lingkup

- Program Regional TFF: Brazil 1992, Indonesia 2000, Guyana 2000, Gabon 2004

- Program Indonesia TFF: Training RIL, Program RIL Verified, Program Dukungan Sertifikasi, Jasa dukungan pada Chain of Custody (CoC), legalitas, dan lain-lain.

- Apa yang disebut dengan RIL: proses, unsur-unsur RIL

- Manfaat dari RIL: Finansial, Lingkungan

- $\quad$ RIL \& Sertifikasi

\section{Presentasi 2. Gusti Hardiyansah (PT SBK)}

- Presentasi diawali dengan penjelasan mengenai gambaran umum PT. SBK sebagai salah satu perusahaan dibawah grup PT. Alas Kusuma yang saat ini masih eksis dan selalu menjadi langganan untuk berbagai kepentingan terkait PHPL.

- Pokok-pokok materi yang dipresentasikan sebagai pembelajaran dari PT. SBK adalah sebagai berikut:

- Pendahuluan: hutan dan kepentingan produktivitas, gambaran umum PT. SBK

- Pendekatan RIL: Bagaimana agar RIL berjalan?

- Pra kondisi yang diperlukan

- Keyakinan manajemen bahwa RIL positif

- Tersedianya tenaga terampil yang ditunjang oleh sarana yang memadai

- Teknik kerja yang tepat

- Motivasi para pelaksana

- Penerapan RIL Skala Operasional: Pembuatan peta pohon dan kontur serta rencana jalan sarad, pelaksanaan kegiatan RIL dan kendala yang dihadapi, catatan penting RIL,

- Pendekatan pengayaan tegakan: Pengayaan tegakan dalam sistem Tebang Pilih Tanam Indonesia Intensif (TPTII)

- Pengayaan tegakan dalam sistem TPTII

- Keunggulan sistem TPTII

\section{Presentasi 3. Boby Bayu (PT SLJ II)}

Presentasi diawali dengan penjelasan mengenai gambaran umum PT SLJ II (lokasi, manajemen, dan lain-lain) dan konteksnya dalam sertifikasi dan RIL sebagai salah satu dari keharusan dalam PHL.

Pokok-pokok materi yang dipresentasikan sebagai pembelajaran dari PT SLJ II adalah sebagai berikut: 
- $\quad$ Sejarah sertifikasi PHPL

- $\quad$ Penataan Kawasan di PT SLJ II: produksi, konservasi, kawasan khusus

- Implementasi RIL: Perencanaan (kesesuaian medan dan alat), pembukaan wilayah hutan, pengembangan cable logging

- RIL dalam penebangan dan penyaradan

- Program lacak balak

- Uji coba legalitas kayu

- Program konservasi tanah dan air

- Penanaman dan pemeliharaan

- Pemetaan partisipatif

- $\quad$ Sistem monitoring DAS terpadu

- Permanent sample plot

- $\quad$ Sertifikasi PHPL dan manfaatnya

- Kesimpulan

\section{Panel Diskusi}

- Selesai presentasi ketiga presenter, moderator membuka sesi diskusi dengan mempersilakan peserta untuk mengajukan beberapa pendapat baik pertanyaan, klarifikasi atau pengalaman lainnya.

- Mengingat sebelumnya dilakukan juga pemaparan dari Ibu Listya Kusumawardani (Dephut), moderator juga mempersilakan kepada peserta untuk mengajukan pertanyaan, klarifikasi dan tanggapan tidak saja kepada ketiga presenter, tetapi juga kepada Ibu Listya.

- Masing-masing penanya, pertanyaan dan tanggapan presenter adalah sebagai berikut:

\section{Pertanyaan:}

\section{Ayi Suyana (BPPK Samarinda)}

- Bagaimana kaitannya dengan penebangan yang tidak boleh lebih dari 8 pohon

- $\quad$ TPTII akan memanen $200 \mathrm{~m}^{3}$ per hektar, apakah sesuai dengan RIL

- Persiapan sertifikasi terkesan sibuk, apakah memang harus seperti itu?

\section{Bondan (PT Inhutani II-APHI)}

Pengalaman sertifikasi di SBK dan SLJ menunjukkan adanya beberapa masalah di Kaltim sebenarnya diluar domain khususnya mengenai kepastian kawasan.

\section{Soeyitno Soedirman (KKS-Unmul)}

KKS dulu memegang mandat dari para pihak yang difasilitasi APHI, mungkin bisa dimulai kembali untuk mendiskusikan kembali khususnya dengan IUPHHK yang masih aktif 


\section{Tanggapan}

\section{Hasbilah (TFF)}

- Memanen sesuai dengan riapnya.

- $\quad$ RIL itu manual, teknologi hanya alat agar proses bisa cepat

\section{Gusti Hardiansyah (PT SBK)}

- Terjadi generalisasi pengertian, PR kebijakan. Untuk alasan keamanan disusun skenario-skenario. Misalnya dalam realitasnya tidak diambil 100\% tapi hanya sekitar $70 \%$, sedangkan tekniknya masih menunggu. Pohon-pohon yang jelek ditebang saja (pendapat Pak Maman-Unmul).

- Sertifikasi yang terkesan sibuk, harus lebih mengedepankan politis khususnya aturannya harus jelas. Untuk sertifikasi yang dilihat harus segmen pasar. Kepastian kawasan merupakan permasalahan yang mendasar, perusahaan harusnya sudah menjadi subsistem negara.

\section{Bobby B (PT SLJ)}

- $\quad$ Sertifikasi sibuk apabila dikaitkan dengan proses sertifikasinya. GCP harus pakai LEI dan FSC apabila mau sertifikasi, dimana masing-masing membawa asesor. Fasilitasi proses sebagai partisipasi aktif dari Unit Manajemen (UM) agar proses sertifikasi berjalan lancar, sehingga terkesan sibuk.

- Kepastian kawasan, tidak berdaya sama sekali sebagai pemegang konsesi dalam hal kepastian kawasan. Komitmen dibangun di lingkup internal (top management) dan segala sistem akan diarahkan menuju sesuai yang diharapkan. Komitmen dari pihak lain masih perlu pembelajaran, tugas FP bagaimana stakeholder lainnya ikut bisa mendukung sertifikasi. Proses pembelajarannya tidak hanya kepada UM melainkan juga kepada seluruh stakeholder. Perlu dibangun pengertian dan satu persepsi bahwa perusahaan akan bekerja dengan jangka waktu lama dan lestari, diharapkan UM juga akan dapat menjadi jaminan pekerjaan bagi penduduk lokal.

- Ajakan untuk diskusi dengan KKS, akan dimulai dengan berbagai materi seperti sistem silvikultur dan lain-lain.

\section{Listya Kusumawardani (Dephut)}

- Pemerintah bukan superman, pemerintah memerlukan kontribusi dari pihakpihak lain. Delapan pohon per ha datanya berdasarkan plot STREK di Berau, harus direvisi karena masih menganut keseragaman. Perlu pendampingan dari pihak-pihak lain di masa-masa transisi.

- Sertifikasi sibuk, pemegang ijin akan mengamputasi kawasan-kawasan yang bermasalah. Tanggapan dari TFF, CoC ada masalah mengenai log khususnya yang berasal dari IUPHHK ijin Bupati, dimana tidak ada kejelasan mengenai kayu yang dihasilkan. Menhut merubah peta dan Jatah Produksi Tebangan Tahunan (JPT) karena itu yang merupakan inti dari masalah. 


\section{Presentasi Sesi 3. Sertifikasi dan Keanekaragaman Hayati pada Hutan Produksi}

- Materi mengenai Sertifikasi dan Keanekaragaman Hayati pada Hutan Produksi merupakan isu penting terkait kebutuhan dan tuntutan para pihak (utamanya global) menyangkut kelestarian ekologi di hutan produksi. Makalah yang ditampilkan antara lain pengalaman Lembaga Ekolabel Indonesia (LEI) dalam sertifikasi PHL serta pengalaman dan proses yang sedang diinisiasi para pihak (utamanya lembaga kehutanan internasional dalam mengimplementasikan prinsip-prinsip praktek kehutanan terbaik (best forest practices) dengan cara yang juga memberikan manfaat bagi masyarakat lokal dan konservasi ekologi.

- Materi dalam sesi ini disampaikan oleh beberapa narasumber antara lain LEI, Nusa Hijau, WWF dan CIFOR dengan topik-topik sebagai berikut:

1). Sertifikasi Pengelolaan Hutan Lestari LEI Sebagai Peningkat Daya Saing Kehutanan Indonesia oleh Aditya Bayunanda (LEI)

2). Pendekatan Bertahap menuju Sertifikasi dan Jaringan Pasar Internasional oleh Irwan Gunawan (WWF - Program Nusa Hijau)

3). Rencana Testing Panduan ITTO/IUCN untuk konservasi keanekaragaman hayati di hutan produksi oleh Tetra Yanuardi (WWF)

4). Panduan ITTO/IUCN untuk konservasi keanekaragaman hayati di hutan produksi oleh Petrus Gunarso (CIFOR)

- Melalui presentasi dan diskusi antara narasumber dengan para peserta lokakarya diharapkan akan memberikan gambaran umum tentang berbagai isu-isu, tren global dan peluang, serta kemungkinan implementasinya oleh sektor kehutanan dalam pencapaian PHL. Dengan demikian akan diperoleh/terjadi proses pemahaman, pembelajaran, pertukaran pendapat dan pengalaman, serta memperoleh dukungan dalam ujicoba maupun pengembangannya.

- Presentasi dan proses diskusi (tanya jawab) difasilitasi oleh Alfan Subekti dari Tropenbos Internasional (TBI). Proses moderasi dan diskusinya sebagai berikut: 


\section{Presentasi 1. Aditya Bayunanda (LEI)}

Presentasi diawali dengan pengantar umum kondisi hutan dan tuntutan yang menjadi ide dasar ekolabel. Dilanjutkan dengan pengenalan sepintas LEI dan korelasinya dengan lembaga sertifikasi lainnya, organisasi LEI, proses sertifikasi dan insentifinsentif. Secara detail topik-topik yang disampaikan sebagai berikut:

- Latar Belakang

- Kondisi Hutan Indonesia: Pengurangan penutupan hutan, kontribusi illegal logging

- Ekolabel: Pengertian, ide dasar, tujuan

- LEI (latar belakang, legalitas, requirement, pengambilan keputusan, capaian, kerangka standarisasi, sasaran penilaian,

- $\quad$ Proses sertifikasi (di hutan alam) dan SFM

- Insentif-insentif: Premium price, akses pasar, insentif pemerintah, akuntabilitas dan transparansi

\section{Presentasi 2. Irwan Gunawan (WWF-Nusa Hijau)}

Presenter mengawali dengan menyampaikan permohonan maaf karena pemakalah yang sebenarnya Bapak Nurcahyo Adi baru bisa hadir hari ke-2.

Topik-topik presentasi yang disampaikan sebagai berikut:

- The global forest and trade network

- Indonesia-FTN (Nusa Hijau): Legalitas dan latar belakang,

- Mitra Indonesia dan FTN: Pengelola hutan, industri dan perdagangan, perkembangan mitra di Indonesia

- Keuntungan bermitra dengan FTN: Akses pasar, bantuan teknis, dukungan legalitas, kampanye, akses finansial

- Jaringan pasar dan permintaan di tingkat regional

- Kerangka kerja Indonesia-FTN: Pendekatan bertahap menuju sertifikasi

- Prosedur keanggotaan (kemitraan) Indonesia-FTN

- Modul Baseline Audit dan Rencana Aksi untuk Pengelola Hutan

- Kemitraan

- Penutup: Bisnis kehutanan dan reputasinya?

\section{Presentasi 3. Tetra Yanuariadi (WWF)}

Sebagai pembuka presenter mengemukakan alasan topik dengan tema Rencana Testing Panduan ITTO/IUCN dengan isu-isu dan tren global. Presenter juga mengemukakan beberapa pengalamannya dalam mengikuti beberapa pertemuan internasional terkait isu-isu konservasi.

Presentasi diawali dengan penjelasan mengenai ruang lingkup dan program kerja serta isu-isu yang dikelola WWF termasuk WWF di Indonesia. Dilanjutkan dengan topik khusus tentang ujicoba guideline ITTO/IUCN.

- Topik-topik yang disajikan antara lain:

- Elemen-elemen utama uji coba lapangan

- Metodologi: Tempat, waktu, organisasi 
- Pendekatan dan analisis, struktur kuisioner

- Outputs: pandangan, rekomendasi, kendala/hambatan, analisis biaya-manfaat, dan opsi-opsi

- $\quad$ Kerangka dan skedul kerja

\section{Presentasi 4. Petrus Gunarso (CIFOR)}

Presenter mengawali dengan menyampaikan penjelasan tentang keterkaitan antara topik yang akan disampaikan dengan presentasi sebelumnya yang saling berhubungan dan memiliki berbagai kesamaan

Topik-topik yang disajikan antara lain:

- Para pihak utama yang terlibat

- Pertemuan para pakar

- Panduan - bukan regulasi baru

- Inisiatif lainnya yang relevan

- Prinsip dasar

- Kepentingan hutan produksi untuk konservasi keanekaragaman hayati

- Hasil kegiatan CIFOR dan ITTO menunjukkan bahwa masyarakat lokal menghargai keanekaragaman hayati

- Panduan

- Pengalaman dari negara produsen

- Dampak langsung dari panduan tahun 1993

- 10 Prinsip:

Prinsip 1: Kedaulatan dan pilihan sosial

Prinsip 2: Komitmen International

Prinsip 3: Pengetahuan, pembelajaran, dan transfer teknologi, dan peningkatan kapasitas

Prinsip 4: Perbedaan dan peran komplementer dari kategori penggunaan lahan

Prinsip 5: Komitmen politik, kebijakan, dan peraturan perundang-undangan

Prinsip 6: Pengaturan institusi

Prinsip 7: Insentif

Prinsip 8: Fungsi ekosistem hutan dan keragaman habitat

Prinsip 9: Rencana pengelolaan dan keanekaragaman hayati

Prinsip 10: Peran konservasi keanekaragaman hayati pada hutan tanaman

- Bagaimana ITTO mewujudkan panduan ini

- Usulan tahap berikutnya

- Tes di negara produsen

\section{Panel Diskusi}

Selesai presentasi keempat presenter, moderator membuka sesi diskusi dengan mempersilakan peserta untuk mengajukan beberapa pendapat baik pertanyaan, klarifikasi atau pengalaman lainnya. Pertanyaan dan tanggapannya sebagai berikut: 


\section{Pertanyaan:}

\section{Soeyitno Soedirman (KKS-Unmul)}

- $\quad$ Sejauh mana LEI mencoba untuk menjadi suatu indikator yang bisa diterima di sini supaya kita tidak bingung, kita juga mempunyai skema ITTO, skema LPI, skema Smartwood, dan ide dari funding lainnya. Beberapa yang sudah ada dan dikeluarkan nasionalismenya kurang sehingga perlu diperjuangkan agar justru skema LEI bisa menginternasional sebagaimana dulu pernah dicita-citakan Pak Emil Salim saat mendirikan LEI

- Masalah Orde Baru, kita semua tinggal di hutan tapi semuanya berurusan dengan banyak sektor, sering kali kita tidak melihat secara global tentang hutan itu sendiri. Rimbawan selalu kerja di hutan dan hutan selalu bersinggungan dengan pihak-pihak lain. Perlu ada tekad dari rimbawan agar ada penghargaan bagi jasa-jasa lingkungan terkait dengan konservasi, perlu komunikasi dengan pihak luar

\section{Tanggapan}

\section{Aditya (LEI)}

Selama ini sumber selalu FSC secara global, tapi dalam prosesnya harus melalui grade-grade dimana LEI bisa bermain di situ. Kayu global hanya 5\% berasal dari kayu tropis. Sertifikasi LEI juga diminati oleh buyer-buyer internasional seperti dari Jepang. Namun demikian kuncinya adalah suplai kayu yang bersertifikat sebagai alat promosi. LEI juga bersifat sebagai lembaga pengarah kepada buyer dimana harus mendapatkan kayu legal yang bersertifikat. Permasalahannya mudah ditangani dari aspek produksinya. LEI optimis dalam konteks global, sertifikasi LEI akan tetap laku.

\section{Petrus Gunarso (CIFOR)}

- Diperlukan juru bicara untuk berbicara dengan sektor lain, tidak mudah untuk mendiskusikan bahwa biodiversity itu ada nilai ekonominya. Tantangan bagi rimbawan secara global bahwa hutan bukan hanya kayu.

- Permasalahannya justru di kehutanan lebih kompleks, dan tidak hanya illegal logging saja. Apakah kita bisa menyuarakan bahwa hutan menyediakan berbagai jasa dan keuntungan ekologi dan sosial.

\section{Tetra (WWF)}

Dengan luas hutan yang sangat luas dan dengan kekayaan keanekaragaman hayati yang tinggi tapi di level internasional masih kurang. Perlu upaya bersama dengan berbagi peran antar semua pihak 


\section{Isu-isu Strategis}

Berdasarkan hasil presentasi dan diskusi (tanya jawab) berikut disajikan isu-isu strategis yang menjadi temuan dan kesimpulan sesi presentasi yaitu:

- Identifikasi hambatan jangka pendek menuju GFG melalui skema sertifikasi.

- Internal improvement (dukungan partnership) melalui KKS/APHI/Nusa Hijau atau forum lainnya.

- Dukungan pemerintah (konsistensi kebijakan)

- Implementasi RIL sangat menguntungkan baik dari aspek teknis, finansial, ekologi dan ekonomi

- Berdasarkan pengalaman sebagaimana di PT SBK, banyak ditemukan keunggulan Sistem TPTII dibandingkan sistem silvikultur lainnya.

- Perlu waktu lama untuk mempersiapkan satu unit manajemen memperoleh sertifikasi PHL yang antara lain disebabkan ketiadaan benchmarking dan dukungan para pihak

- Penting untuk membuka diri dan bekerja sama dengan pihak luar

- Komitmen yang kuat dari owner dan top management akan mempercepat ketercapaian sertifikasi PHL

- Secara umum belum banyak insentif dan reward yang diberikan oleh pengusaha yang mempunyai komitmen dan lulus sertifikasi. Namun demikian secara langsung maupun tidak langsung sesungguhnya para pemegang sertifikat ekolabel memperoleh beberapa insentif dari pihak luar antara lain berupa;

- Premium price: Tercatat kenaikan harga sampai dengan 20\% dibandingkan dengan produk yang tidak memiliki sertifikat ekolabel. Ini erat terkait dengan menjadi pemilik sertifikat ekolabel secara internasional nama unit manajemen yang bersangkutan menjadi sangat dikenal.

- Akses pasar yang lebih luas dan keunggulan dalam persaingan. Pembeli dari negara-negara ekosensitif sudah mulai mensyaratkan bahwa produk-produk dari Indonesia memiliki ekolabel, bila ingin terus berdagang di negara-negara tersebut. Mengingat bahwa sekarang ini permintaan kayu bersertifikat jauh di atas suplai maka peluang pasar kayu bersertifikat sangat baik.

- Terdapat juga berbagai insentif pemerintah yang diberikan kepada unit manajemen yang telah memiliki sertifikasi PHL, diantaranya kebijakan self approval RKT, kemudahan ekspor, tidak terkena pemotongan jatah tebangan. 
- Walaupun tidak dipungkiri unit manajemen yang telah memiliki sertifikat ekolabel tidak bebas dari permasalahan, terutama permasalahan sosial, namun dapat dilihat dan dibuktikan bahwa unit manajemen tersebut lebih transparan, memiliki prosedur penanganan yang baik terhadap konflik, dan dapat dengan menggunakan platform sertifikasi menjalin kerjasama yang positif dengan stakeholder di sekitarnya.

- Meskipun isu-isu kelestarian keanekaragaman hayati sudah lama didengungkan, untuk beberapa konteks isu yang merupakan isu dan tren global sangat perlu untuk disosialisasikan secara menyeluruh kepada pihak khususnya pengusaha.

- Perlunya regulasi untuk pengelolaan hutan yang terintegrasi antara produksi kayu dan produk jasa lingkungan. 



\section{Diskusi Kelompok}




\section{Acuan Diskusi Kelompok}

Peserta dibagi atas 2 (dua) Kelompok:

- Kelompok 1. RIL dan Pembelajarannya (moderator: Hari Priyadi)

- Kelompok 2. Sertifikasi dan Keanekaragaman Hayati (moderator: Nurcahyo Adi dan Chairul Saleh

Permasalahan yang dibahas di dalam diskusi kelompok sebagai berikut:

\section{Kelompok 1. RIL dan pembelajarannya}

1). Mengapa Anda tertarik dalam RIL? Apa manfaat dan keuntungan dalam melaksanakan RIL? Insentif apa yang diterima setelah Anda melaksanakan RIL dan mendapatkan sertifikat SFM (IUPHHK yang telah melaksanakan RIL)

2). Mengapa Anda belum atau tidak melaksanakan RIL? Masalah-masalah apa yang dihadapi sehingga tidak melaksanakan RIL? (Kepada IUPHHK yang belum/ tidak melaksanakan RIL)

3). Apakah Anda mendengar tentang SK No. 274/VI-PHA/2001 mengenai keharusan IUPHHK melaksanakan RIL? Apakah efektif surat edaran tersebut? Jika tidak efektif bagaimana agar aturan/regulasi menjadi lebih efektif (Kepada perwakilan Dephut/Dinas).

\section{Kelompok 2. Sertifikasi dan keanekaragaman hayati}

1). Bagaimana masalah keanekaragaman hayati di hutan produksi diperhatikan oleh perusahaan atau instansi Anda?

2). Apakah Perusahaan Anda tertarik untuk dijadikan lokasi ujicoba panduan ITTO?

3). Faktor-faktor apa yang membuat perusahaan Anda tertarik/tidak tertarik untuk dijadikan lokasi ujicoba panduan ITTO? 


\section{Proses dan Hasil}

\section{Kelompok 1. RIL dan Pembelajarannya}

\section{Partisipan:}

1). Hari Priyadi (CIFOR)

2). Hasbillah (TFF)

3). Syahrani (PT KBT)

4). Ayi Suyana (BPPK Kalimantan)

5). Desi W (Dishut Paser)

6). Purnamasari (Dishut Paser)

7). Boby Bayu (PT SLJ)

8). Art Klassen (TFF)

9). Michel (Mahasiswa, TBI)

10). Sultan Lubis (TBI)

11). M. Agung Sardjono (CSF, Reviewer)

12). Wakil dari PT DSN

13). Resa Prihadi (PT SLJ II)

14). Susilo (PT Rizki KR)

15). Wayan $S$ (PT Roda Mas)

16). Edison (PT Inhutani I Bpp)

17). Wahyu (PT Timber Dana)

18). Yosef Ruslim (Fahutan Unmul-TNC)

19). Bondan (PT Inhutani II-APHI)

20). Yulius H (PT Hanurata)

21). Gusti H (PT Alas Kusuma)

22). Alfa (TBI)

23). Akhmad Wijaya (Bioma, Notulensi)

24). Esa (Bioma, dokumenter)

25). Esmeralda (TBI)

\section{Proses:}

- Diskusi kelompok difasilitasi oleh Hari Priyadi (CIFOR) dan dibantu oleh Hasbillah (TFF) dengan metode curah pendapat.

- Proses dimulai dengan perkenalan semua yang terlibat dalam proses diskusi 
dengan metode peserta yang telah memperkenalkan nama dan asal instansi/ institusi menunjuk peserta lain untuk memperkenalkan diri.

- Selesai perkenalan fasilitator membuka sesi diskusi dengan penjelasan singkat topik yang akan dibahas berdasarkan guideline yang tersedia.

- Diskusi dimulai dengan topik RIL, manfaat, keuntungan dan insentif yang diperoleh dengan terlebih dahulu mempersilakan pengalaman dari perusahaanperusahaan yang telah melaksanakan RIL yaitu PT. SLJ dan PT SBK. Dilanjutkan curah pendapat dari perusahaan dan institusi lainnya tentang pengalaman dan pembelajaran dalam sertifikasi dan RIL termasuk kendala, hambatan dan komitmennya.

- Setelah diskusi dan curah pendapat, untuk rekomendasi dan masukan konkret, fasilitator mempersilakan peserta menulis dalam kertas metaplan yang dibagikan. Masing-masing kertas metaplan kuning untuk masukan ke pemerintah (birokrasi), kertas metaplan hijau untuk masukan ke perusahaan (owner) dan kertas metaplan biru untuk masukan ke institusi lainnya (Akademik, lembaga penelitian dan pengembangan (litbang), LSM, lembaga internasional, dan lainlain).

- Rekomendasi dan masukan yang ditulis dalam kertas metaplan dikumpulkan dan ditempel di papan plipchart sesuai pengelompokannya. Sebelum diskusi dan curah pendapat ditutup fasilitator meminta salah seorang untuk mewakili presentasi kelompok yaitu terpilih Pak Yosep Ruslim (TNC - Unmul)

\section{Hasil Diskusi:}

Hasil-hasil dari proses diskusi disajikan dalam matriks rekaman proses sebagaimana dalam Tabel 1 berikut:

Tabel 1. Matriks Rekaman Hasil Diskusi Kelompok 1

\begin{tabular}{|c|c|}
\hline $\begin{array}{l}\text { Pedoman Umum } \\
\text { (Kata Kunci) }\end{array}$ & Diskusi \\
\hline \multirow[t]{2}{*}{$\begin{array}{l}\text { 1. Mengapa tertarik dengan } \\
\text { RIL? Apa manfaat dan } \\
\text { keuntungan dalam } \\
\text { melaksanakan RIL? }\end{array}$} & $\begin{array}{l}\text { Boby Bayu dan Resa (PT.SLJ) } \\
\cdot \quad \text { Memperoleh sertifikat } \\
\text { - } \quad \text { Ada support awal melalui kerjasama dengan GTZ } \\
\cdot \quad \text { Manfaat ekologi, terutama meminimalkan dampak fisik } \\
\cdot \quad \text { Reward bagi divisi logging (unggul dalam kegiatan } \\
\quad \text { logging) } \\
\text { - } \quad \text { Teknologi skyline di PT.SLJ sebagai bagian dari RIL }\end{array}$ \\
\hline & $\begin{array}{l}\text { (Gusti H) PT. Alas Kusuma Group/PT. SBK } \\
\text { - Swasta sebagai pedagang, sebagai pedagang harus } \\
\text { luas jaringannya. Kekuatan eksternal mendorong } \\
\text { perusahaan untuk melakukan RIL. } \\
\text { - Secara internal rimbawan harus komitmen terhadap } \\
\text { keterjagaan lingkungan, dan RIL merupakan aspek dari } \\
\text { komitmen tersebut }\end{array}$ \\
\hline
\end{tabular}




\begin{tabular}{|c|c|}
\hline $\begin{array}{l}\text { Pedoman Umum } \\
\text { (Kata Kunci) }\end{array}$ & Diskusi \\
\hline & $\begin{array}{l}\text { Pak Wayan (Roda Mas) } \\
\text { - Secara umum, akses pasar memang faktor penting } \\
\text { tetapi di PT. Roda Mas faktor internal masih } \\
\text { dominan, sehingga meski keinginan ada, RIL secara } \\
\text { implementatif belum direalisasikan } \\
\end{array}$ \\
\hline & $\begin{array}{l}\text { Syahrani (PT. Kemakmuran Berkat Timber) } \\
\text { - Berawal dari kebijakan perusahaan untuk memperoleh } \\
\text { ISO } 14000 \text {. Salah satu aspek penting yaitu kegiatan } \\
\text { pembalakan di aspek jalan sarad. Saat ini masih terus } \\
\text { dicoba meski masih banyak kendala }\end{array}$ \\
\hline & $\begin{array}{l}\text { Yosef Ruslim (TNC/Fahutan Unmul) } \\
\text { - } \quad \text { Apabila sukses RIL berarti 30\% dari SFM } \\
\text { - } \quad \text { Dalam RIL porsi nilai besar/tinggi }\end{array}$ \\
\hline & $\begin{array}{l}\text { Bondan (APHI-PT. Inhutani I) } \\
\text { - } \quad \text { RIL dari dulu tertarik, sebagai BUMN ada ketertarikan } \\
\text { untuk menjadi model dan pencapaian sertifikasi } \\
\text { - } \quad \text { RIL setengah perjalanan SFM } \\
\text { - } \\
\text { Ada dukungan dari lembaga pendamping (CIFOR, KKS, } \\
\text { TFF, GTZ) }\end{array}$ \\
\hline & $\begin{array}{l}\text { Ayi, S (BPPK Kalimantan) } \\
\text { - } \quad \text { Keuntungan ekologi/lingkungan (hasil riset) } \\
\text { - } \quad \text { RIL pengembangan TPTII, secara operasional } \\
\text { penekanannya hanya pada jalan sarad. Sehingga tidak } \\
\text { ada alasan untuk IUPHHK tidak melakukannya. } \\
\text { - } \quad \text { Apabila IUPHHK melakukan TPTII secara benar dan } \\
\quad \text { konsisten maka hanya bergeser sedikit saja dengan RIL }\end{array}$ \\
\hline \multirow[t]{4}{*}{$\begin{array}{l}\text { 2. Insentif apa yang } \\
\text { diterima setelah anda } \\
\text { melaksanakan RIL dan } \\
\text { mendapatkan sertifikat } \\
\text { SFM? }\end{array}$} & $\begin{array}{l}\text { Boby Bayu dan Reza (PT.SLJ) } \\
\text { - Secara umum dari pemerintah tidak/belum ada, } \\
\text { tetapi bagi internal SLJ sendiri, reward-nya adalah } \\
\text { kebanggaan bagi divisi logging sangat kompetitif antar } \\
\text { divisi } \\
\text { - RIL berangkat dari tingkat manajemen menengah ke } \\
\text { atas, pengalaman di Sumalindo bukan tanpa kendala } \\
\text { terutama di tingkat bawah. }\end{array}$ \\
\hline & $\begin{array}{l}\text { Gusti, H (PT. Alas Kusuma Group/PT. SBK) } \\
\text { - } \quad \text { Tidak/belum ada, justru ada penambahan biaya insentif } \\
\text { untuk kunjungan, studi, dan lain-lain } \\
\text { - Insentif secara tidak langsung adalah PT. SBK dikenal, } \\
\text { sedangkan insentif langsung berdasarkan hasil studi } \\
\text { adalah manfaat ekologi dan finansial }\end{array}$ \\
\hline & $\begin{array}{l}\text { Hasbillah (TFF) } \\
\text { • Antara yang menerapkan dan tidak menerapkan masih } \\
\text { memperoleh perlakuan birokrasi yang sama. }\end{array}$ \\
\hline & $\begin{array}{l}\text { Bondan (PT. Inhutani II) } \\
\text { - Sebelum mengenal sertifikasi dan RIL, asal bisa } \\
\text { melakukan TPTII sesuai standar Dephut sebenarnya } \\
\text { sudah realiasasi dari RIL dan sertifikasi } \\
\text { - Janji Dephut:JPT diberikan sesuai riap di luar kuota, } \\
\text { faktanya } 2006 \text { ini masih dalam kuota. } \\
\text { - Penting untuk adanya self assessment }\end{array}$ \\
\hline
\end{tabular}




\begin{tabular}{|c|c|}
\hline \multirow[t]{2}{*}{$\begin{array}{l}\text { Pedoman Umum } \\
\text { (Kata Kunci) }\end{array}$} & Diskusi \\
\hline & $\begin{array}{l}\text { Ayi Suyana (BPPK Kalimantan) } \\
\text { - Sistem silvikultur akan diberikan kebebasan kepada } \\
\text { IUPHHK }\end{array}$ \\
\hline \multirow[t]{9}{*}{$\begin{array}{l}\text { 3. Mengapa anda belum } \\
\text { atau tidak melaksanakan } \\
\text { RIL? Masalah-masalah apa } \\
\text { yang dihadapi sehingga } \\
\text { tidak melaksanakan RIL? }\end{array}$} & $\begin{array}{l}\text { Bondan (APHI-PT. Inhutani II) } \\
\text { - } \quad \text { Faktor internal dan eksternal merupakan faktor } \\
\text { dominan yang menyebabkan RIL mengalami stagnasi } \\
\text { (komitmen internal tidak cukup dan perlu di-backup } \\
\text { oleh komitmen eksternal) }\end{array}$ \\
\hline & $\begin{array}{l}\text { Edison (PT. inhutani I) } \\
\cdot \quad \text { Tujuan memperoleh sertifikasi } \\
\text { - } \quad \text { Kendala internal dan eksternal } \\
\end{array}$ \\
\hline & $\begin{array}{l}\text { Wahyu P (PT.Timberdana) } \\
\text { - } \quad \text { Pernah pada tahun } 1998 \text { ada penilaian dari APHI untuk } \\
\text { pencapaian sertifikasi } \\
\text { - RIL tidak sulit tetapi mengalami hambatan, ke depan } \\
\text { akan berusaha untuk belajar khususnya melalui LPI }\end{array}$ \\
\hline & $\begin{array}{l}\text { (PT. Gunung Gajah) } \\
\text { - Baru dalam tahap pelatihan, kendala SDM di tingkat } \\
\text { lapangan masih dominan. Sebagian besar karyawan di } \\
\text { tingkat lapangan (operator) cenderung inginnya yang } \\
\text { mudah-mudah sebagaimana kebiasaan. }\end{array}$ \\
\hline & $\begin{array}{l}\text { (PT.DSN) } \\
\text { - Baru dalam tahap awal pengimplementasian RIL saat } \\
\text { perpanjangan IUPHHK. } \\
\text { Ada komitmen internal tetapi belum banyak } \\
\text { direalisasikan mengingat kendala teknis, SDM, dan lain- } \\
\text { lain. }\end{array}$ \\
\hline & $\begin{array}{l}\text { Yulius H (PT. Hanurata) } \\
\text { - } \quad \text { Sudah lama dilakukan terutama untuk beberapa } \\
\text { tahapan TPTII yang secara konseptual mendekati RIL. } \\
\text { - } \quad \text { Sebagai wujud komitmen rimbawan terhadap SFM } \\
\text { - } \quad \text { Komitmen sudah ada terutama setelah munculnya LPI } \\
\end{array}$ \\
\hline & $\begin{array}{l}\text { Hasbillah (TFF) } \\
\text { - Secara umum ada dua kendala yaitu manajemen dan } \\
\text { teknis }\end{array}$ \\
\hline & $\begin{array}{l}\text { Purnamasari (Dishut Kabupaten Pasir) } \\
\text { - Informasi tentang RIL masih minim }\end{array}$ \\
\hline & $\begin{array}{l}\text { Wayan (PT. Roda Mas) } \\
\text { - Kesulitan penting yaitu belum ada peta kontur dan } \\
\text { peta potensi yang akurat. } \\
\text { - Ketidakpastian kawasan terutama regulasi dalam bisnis } \\
\text { yang berbasis kayu, sementara investasi sudah besar } \\
\text { - Insentif dari pemerintah tidak/belum mendorong } \\
\text { perusahaan untuk melakukan komitmen yang lebih } \\
\text { baik termasuk RIL. }\end{array}$ \\
\hline
\end{tabular}




\begin{tabular}{|c|c|}
\hline $\begin{array}{l}\text { Pedoman Umum } \\
\text { (Kata Kunci) }\end{array}$ & Diskusi \\
\hline & $\begin{array}{l}\text { Ratah Timber } \\
\text { - Kesulitan mengubah watak karena terbiasa dengan } \\
\text { 'budaya gampang' }\end{array}$ \\
\hline \multirow[t]{8}{*}{$\begin{array}{l}\text { 4. Sebagian besar dalam } \\
\text { kerangka pencapaiannya } \\
\text { adalah sertifikasi, } \\
\text { mengapa tujuan RIL } \\
\text { adalah sertifikasi? }\end{array}$} & $\begin{array}{l}\text { Awang (PT.DSN) } \\
\text { - Sertifikasi hanya kemauan pembeli, standarnya juga } \\
\text { berbeda-beda } \\
\text { - Orientasi bisnis kayu, bukan bisnis ekologi. Demikian } \\
\text { juga di lembaga pendidikan lebih terfokus pada } \\
\text { orientasi kayu bukan ekologi. }\end{array}$ \\
\hline & $\begin{array}{l}\text { Boby Bayu (PT.SLJ) } \\
\text { - Di mata pengusaha, orientasi memang kayu sesuai } \\
\text { dengan ijinnya yaitu IUPHHK. } \\
\text { Owner bukan forester, orientasi bisnis cenderung lebih } \\
\text { besar dibandingkan ekologi } \\
\text { - Untuk bisnis di luar kayu bagaimana dengan ijinnya? } \\
\text { SLJ punya } 75 \text { kawasan lindung yang prospektif untuk } \\
\text { pengusahaan selain kayu. }\end{array}$ \\
\hline & $\begin{array}{l}\text { Yulius H (PT. Hanurata) } \\
\text { • Sertifikasi sebagai alat kontrol untuk implementasi di } \\
\text { lapangan. }\end{array}$ \\
\hline & $\begin{array}{l}\text { Hari Priyadi (CIFOR) } \\
\text { - } \quad \text { Pengalaman di Sabah, Danum valley ada konsep } \\
\text { terintegrasi antara bisnis kayu dan bisnis lainnya } \\
\text { (wisata, penelitian, dan lain-lain) }\end{array}$ \\
\hline & $\begin{array}{l}\text { Wayan (PT. Roda Mas) } \\
\text { - Premium price belum banyak memberi insentif yang } \\
\text { baik bagi pelaku bisnis yang punya komitmen. Proses } \\
\text { birokrasi masih berbelit, RIL hanya target LPI. }\end{array}$ \\
\hline & $\begin{array}{l}\text { Gusti (PT. SBK) } \\
\text { - Untuk basis bisnis di luar kayu, terutama wisata faktor } \\
\text { penting adalah keamanan, aksesibilitas, dan sarana } \\
\text { penunjang } \\
\text { - Kuncinya di regulasi, jangankan HPT, sedangkan di HL } \\
\text { saja ada pertambangan }\end{array}$ \\
\hline & $\begin{array}{l}\text { Ayi (BPPK Kalimantan) } \\
\text { - Mungkin benar secara teknis perlu dilihat untuk Hutan } \\
\text { Produksi Terbatas. }\end{array}$ \\
\hline & $\begin{array}{l}\text { Hasbillah (TFF) } \\
\text { - } \quad \text { Regulasinya sudah ada untuk HPT, untuk kelerengan } \\
\text { tertentu tidak ada penebangan sehingga di HPT tidak } \\
\text { ada RIL }\end{array}$ \\
\hline $\begin{array}{l}\text { 5. Apakah anda mendengar } \\
\text { tentang SK No. 274/VI- } \\
\text { PHA/2001 mengenai } \\
\text { keharusan IUPHHK } \\
\text { melaksanakan RIL? }\end{array}$ & $\begin{array}{l}\text { Purnamasari dan Desi W (Dishut Kabupaten Pasir) } \\
\text { - Di tingkat birokrasi di daerah informasi tentang RIL } \\
\text { masih minim dan mungkin juga banyak yang belum } \\
\text { tahu karena latar belakang yang beragam termasuk } \\
\text { dari non kehutanan }\end{array}$ \\
\hline
\end{tabular}




\begin{tabular}{|c|c|c|}
\hline & $\begin{array}{l}\text { Pedoman Umum } \\
\text { (Kata Kunci) }\end{array}$ & Diskusi \\
\hline \multirow{5}{*}{\multicolumn{2}{|c|}{$\begin{array}{l}\text { Apakah efektif surat } \\
\text { edaran tersebut? Jika tidak } \\
\text { efektif bagaimana agar } \\
\text { aturan/regulasi menjadi } \\
\text { lebih efektif? }\end{array}$}} & $\begin{array}{l}\text { Khusus di Kabupaten Pasir, Dinas Kehutanan baru } \\
\text { terbentuk tahun } 2002 \text { dan baru dalam proses } \\
\text { konsolidasi } \\
\text { - Informasi selama di perkuliahan juga minim karena } \\
\text { jurusan dan konsentrasi studi yang berbeda. }\end{array}$ \\
\hline & & $\begin{array}{l}\text { Yulius H (PT. Hanurata) } \\
\text { • } \quad \text { Tantangan kita sebagai forester untuk menanamkan } \\
\text { SFM kepada owner. }\end{array}$ \\
\hline & & $\begin{array}{l}\text { Syahrani (Roda Mas Group/PT. KBT) } \\
\text { - Sertifikasi bisa meyakinkan owner, dalam perusahaan } \\
\text { ada owner dan rimbawan. Isu sertifikasi bisa menjadi } \\
\text { alat untuk rimbawan meyakinkan kepada owner } \\
\text { bahwa RIL sebagai salah satu bagian dari pencapaian } \\
\text { sertifikasi perlu dilakukan. }\end{array}$ \\
\hline & & $\begin{array}{l}\text { Gusti H (PT. SBK) } \\
\text { - } \quad \text { llustrasi anak tangga:Tangga 1:tingkat operator, } \\
\text { Tangga 2: tingkat supervisor, Tangga 3: tingkat manajer } \\
\text { menengah;Tangga 4: tingkat litbang; Tangga 5: tingkat } \\
\text { manajer;Tangga 6: tingkat top manajer;Tangga 7: } \\
\text { tingkat owner. Pengaruh ketertarikan dapat dari } \\
\text { tangga } 1 \text { (operator) ke tangga } 7 \text { (pemilik) } \\
\text { - RIL seharusnya menjadi ideologi }\end{array}$ \\
\hline & & $\begin{array}{l}\text { Ayi (BPPK Kalimantan) } \\
\text { - } \quad \text { Dengan persoalan apapun (kendala eksternal dan } \\
\text { internal) tidak ada alasan tidak bisa melakukan RIL. } \\
\text { - } \quad \text { Secara teknis RIL tidak merugikan }\end{array}$ \\
\hline \multirow[t]{2}{*}{6.} & \multirow[t]{2}{*}{$\begin{array}{l}\text { Masukan untuk RIL dan } \\
\text { Sertifikasi? }\end{array}$} & $\begin{array}{l}\text { Untuk Perusahaan } \\
\text { - } \quad \text { Harus ada komitmen, dukungan serta visi dan misi } \\
\text { - } \quad \text { Kalam meahlian teknis RIL sebagai salah satu syarat rekruitmen } \\
\text { - } \quad \text { Sosialisasi dan dissemininasi keuntungan/kelebihan RIL } \\
\text { (finansial, ekologi, pasar, dan lain-lain) kepada owner } \\
\text { - Kegiatan operasional tidak dikontrakkan } \\
\text { - Perlu pendampingan/kerjasama dan pengembangan } \\
\text { - } \quad \text { Peningan untuk ujicoba RIL } \\
\text { - Pembinatan SDM dan teknis dalam implementasi RIL } \\
\text { - Inventarisasi potensi (kayu) secara akurat } \\
\text { - Reward dan insentif untuk karyawan yang } \\
\text { mengimplementasikan RIL }\end{array}$ \\
\hline & & $\begin{array}{l}\text { Untuk Pemerintah (Birokrasi) } \\
\text { - } \quad \text { Membentuk regulasi yang konsisten dan menjamin } \\
\text { - } \quad \text { Sepastian (hukum, kawasan) } \\
\text { (finansiasi, dan dissemininasi keuntungan/kelebihan RIL } \\
\text { - } \quad \text { Peningkatan SDM kehutanan dalam SFM khususnya RIL } \\
\text { - Kebijakan untuk self assessment }\end{array}$ \\
\hline
\end{tabular}




\begin{tabular}{|c|c|}
\hline $\begin{array}{l}\text { Pedoman Umum } \\
\text { (Kata Kunci) }\end{array}$ & Diskusi \\
\hline & $\begin{array}{l}\text { - Ada insentif, reward, apresiasi untuk perusahaan yang } \\
\text { telah menjalankan SFM dengan baik (premium price, } \\
\text { perpajakan, perijinan, birokrasi TUK, JPT, dan lain-lain) } \\
\text { - Sinkronisasi kebijakan pusat dan daerah (kewenangan, } \\
\text { pengelolaan kawasan, tata ruang, dan lain-lain) } \\
\text { - SFM (termasuk RIL) menjadi persyaratan memperoleh } \\
\text { RKT } \\
\text { - Mengembangkan jaringan dengan NGO dan lembaga } \\
\text { internasional yang komitmen SFM } \\
\text { - Fasilitasi dan mediasi untuk pengembangan RIL } \\
\text { - Transformasi kebijakan untuk tata kelola hutan } \\
\text { (khususnya IUPHHK) yang baik, benar dan bersih dari } \\
\text { KKN } \\
\text { Kebebasan dalam memilih sistem silvikultur sesuai } \\
\text { kondisi }\end{array}$ \\
\hline & $\begin{array}{l}\text { Lain-lain (NGO's, Akademik, Donor, dan lain-lain) } \\
\text { - } \quad \text { Fasilitasi dan mediasi tidak hanya IUPHHK tetapi juga } \\
\text { Birokrat (dinas, instansi terkait) } \\
\text { - Sosialisasi, disseminasi dan promosi kepada semua } \\
\text { stakeholder terus menerus } \\
\text { - Mendorong implementasi reward, insentif, premium } \\
\text { price, apresiasi dan akses pasar } \\
\text { - Kerjasama diperluas untuk IUPHHK besar, menengah, } \\
\text { kecil dan akses yang variatif } \\
\text { - Mengembangkan plot permanen dan pusat } \\
\text { pendidikan dan latihan }\end{array}$ \\
\hline
\end{tabular}

\section{Kelompok 2. Sertifikasi dan keanekaragaman hayati}

\section{Partisipan:}
1). Nurcahyo Adi (WWF, Fasilitator)
2). Chairul Saleh (WWF, Co Fasilitator)
3). Awal Marisah (PT Inhutani I)
4). Abdurrahman (BTR Banjarbaru Kalsel)
5). Sri Wahyudi (PT Ratah Timber)
6). Suharyanto (PT Rodamas)
7). Petrus Gunarso (CIFOR)
8). M. Ibrahim (PT Kemakmuran Berkah Timber)
9). Slamet (PT Sumalindo)
10). Joko S (PT Sumalindo)
11). Alfian (PT Timberdana)
12). Hamid (PT Sumalindo)
13). Hajar Dewanto (PT Inhutani II SMD)
14). Suyitno S. (KKS Kaltim)
15). Aditya (LEI) 
16). Terta Y. (WWF Jakarta)

17). Wiwin E. (WWF Samarinda)

18). Agung F. (CIFOR)

19). Kresno D. Santosa (CIFOR)

20). Alfan (Tropenbos)

21). Dedy (PT Karya Lestari)

22). Enggar (BLK Samarinda)

23). Irwan (WWF Samarinda)

24). Anton Hidayat (Bioma, Notulen)

\section{Proses:}

- Diskusi kelompok difasilitasi oleh Nurcahyo Adi (WWF) dan dibantu oleh Chairul Saleh (WWF) dengan metode curah pendapat;

- Proses dimulai dengan perkenalan semua yang terlibat dalam proses diskusi dengan metode perkenalan langsung secara bergantian;

- Selesai perkenalan fasilitator membuka sesi diskusi dengan penjelasan singkat topik yang akan dibahas berdasarkan guideline dan hubungannya dengan isu sertifikasi;

- Diskusi dimulai dengan topik sertifikasi, biodiversity, kebutuhan, dan dilanjutkan untuk saran/masukan sebagai insentif yang diharapkan terutama bagi pengusaha;

- $\quad$ Proses diskusi dilakukan dengan metode jaring pendapat secara tertulis melalui kertas metaplan sesuai urutan topik, dan dilanjutkan dengan diskusi untuk topik atau tema yang strategis maupun perlu klarifikasi;

- Hasil-hasil diskusi ditabulasi sesuai topik untuk dipresentasikan. Sebelum diskusi dan curah pendapat ditutup fasilitator meminta salah seorang untuk mewakili kelompok untuk presentasi yaitu terpilih Pak Joko Sarjito (PT SLJ).

\section{Hasil Diskusi:}

Hasil-hasil dari proses diskusi disajikan dalam matrik rekaman proses sebagaimana dalam Tabel 2 berikut:

Tabel 2. Matriks Rekaman Hasil Diskusi Kelompok 2

\begin{tabular}{|c|c|}
\hline $\begin{array}{l}\text { Pedoman Umum } \\
\text { (Kata Kunci) }\end{array}$ & Diskusi \\
\hline 1. Sertifikasi? & - Proses verifikasi unit manajemen oleh suatu lembaga sertifikasi. \\
\hline $\begin{array}{l}\text { 2. Mengapa perlu } \\
\text { biodiversity? }\end{array}$ & $\begin{array}{l}\text { - } \\
\text { - Pandai kayu hanya } 5 \% \text { dari hutan produksi } \\
\text { produksi } \\
\text { - Panduan membantu untuk melindungi dan memanfaatkan } \\
\text { biodiversity di hutan produksi } \\
\text { - Konsep ekologi satwa belum banyak dipahami oleh IUPHHK } \\
\text { sehingga kebutuhan konservasi di hutan produksi muncul } \\
\text { belakangan, perlu sosialisasi dan pendampingan } \\
\text { - IUPHHK hanya mendaftar/mencatat potensi kayu dan belum } \\
\text { memperhatikan biodiversity sehingga perlu ada regulasi khusus }\end{array}$ \\
\hline
\end{tabular}




\begin{tabular}{|c|c|}
\hline $\begin{array}{l}\text { Pedoman Umum } \\
\text { (Kata Kunci) }\end{array}$ & Diskusi \\
\hline 3. & $\begin{array}{l}\text { Masyarakat banyak yang belum memahami peraturan } \\
\text { perundang-undangan perlindungan hidupan liar } \\
\text { IUPHHK sudah menerapkan kawasan plasma nutfah ( } 300 \\
\text { ha/blok tebangan), apakah ini bisa dianggap sebagai 'zona } \\
\text { konservasi' atau cikal bakal konservasi biodiversity di hutan } \\
\text { produksi. } \\
\text { - } \quad \text { Panduan harus bisa menjadi pelengkap peraturan yang sudah } \\
\text { ada di hutan produksi untuk menilai biodiversity } \\
\text { - Sumalindo Il punya } 75.000 \text { ha (dari } 2000 \text { ha) kawasan lindung } \\
\text { (kawasan yang memiliki HCVF) } \\
\text { Kawasan konservasi di hutan produksi sebaiknya bisa juga } \\
\text { dimanfaatkan biodiversity-nya, misalnya oleh masyarakat, hal ini } \\
\text { juga merupakan bagian dari proses sertifikasi. } \\
\text { NTFP lebih difokuskan untuk dimanfaatkan masyarakat, namun } \\
\text { dalam menerapkan pemanfaatan biodiversity di hutan produksi } \\
\text { perlu kehati-hatian. }\end{array}$ \\
\hline $\begin{array}{l}\text { 4. Masalah } \\
\text { keanekaragaman } \\
\text { hayati di hutan } \\
\text { produksi }\end{array}$ & $\begin{array}{l}\text { Masalah kehati diperlukan akses dan pemanfaatannya (jasa } \\
\text { lingkungan, wisata, dan lain-lain) } \\
\text { - Kehati tidak hanya di kawasan konservasi tetapi di kawasan } \\
\text { produksi malah bisa punya nilai konservasi } \\
\text { - Pengelolaan hutan sebaiknya berdasarkan ekosistem tidak } \\
\text { berdasarkan fungsi hutan sehingga diperlukan komitmen dari } \\
\text { pemerintah/peraturan dan pengusaha }\end{array}$ \\
\hline $\begin{array}{l}\text { 5. Kebutuhan } \\
\text { Pengusaha }\end{array}$ & $\begin{array}{l}\text { Disseminasi dan pemahaman yang komprehensif dari } \\
\text { berbagai istilah dan terminologi seperti antara lain: (Ekologi } \\
\text { satwa, Plasma nutfah, Koridor satwa, Zona penyangga (buffer } \\
\text { zone), Kebun bibit, HCVF, Konservasi, Keanekaragaman hayati, } \\
\text { Pemanfaatan yang berkelanjutan, Kebutuhan vs. Formalitas, dan } \\
\text { lain-lain) } \\
\text { - Pemanfaatan kawasan lindung untuk pemanfaatan lain (jasa } \\
\text { lingkungan, wisata, dan lain-lain) } \\
\text { - Internalisasi sumberdaya di level operasional } \\
\text { Konvensi (CBD, CITES, dan lain-lain), bagaimana hubungannya } \\
\text { dengan aturan }\end{array}$ \\
\hline $\begin{array}{l}\text { 6. Kebutuhan } \\
\text { Pemerintah }\end{array}$ & $\begin{array}{l}\text { - Aturan/kebijakan tidak dikotak-kotakan/terlalu sektoral yang } \\
\text { mengakibatkan benturan kepentingan konservasi vs. Konservasi } \\
\text { Perlu insentif dan reward terhadap pengusaha yang kelola } \\
\text { konservasi, antara lain: } \\
\text { a. Pajak/pembebasan PBB oleh Pemda/PAD } \\
\text { b. JPT (kemudahan, konsistensi, dan lain-lain) }\end{array}$ \\
\hline $\begin{array}{l}\text { 7. Saran/masukan } \\
\text { untuk insentif } \\
\text { yang diharapkan }\end{array}$ & 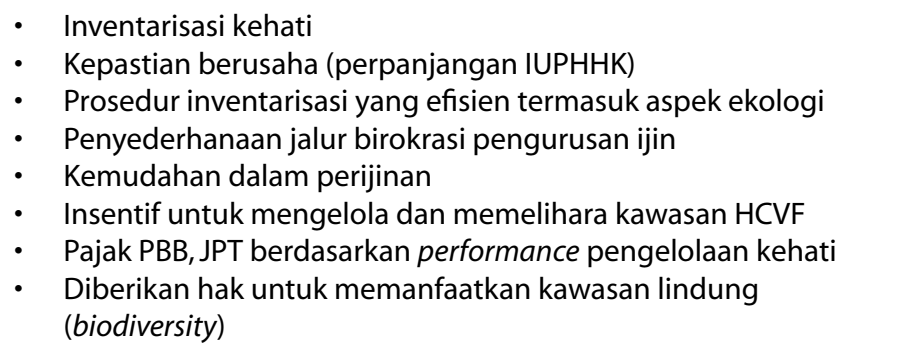 \\
\hline
\end{tabular}




\begin{tabular}{|c|c|}
\hline $\begin{array}{l}\text { Pedoman Umum } \\
\text { (Kata Kunci) }\end{array}$ & Diskusi \\
\hline & 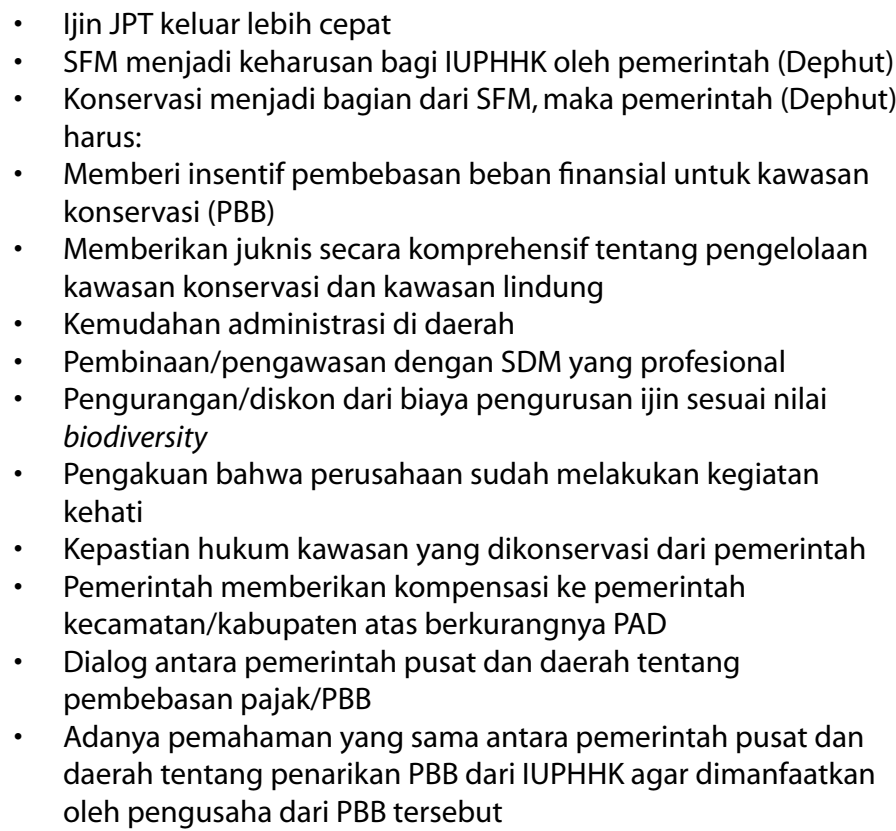 \\
\hline $\begin{array}{l}\text { 8. Kebutuhan dan } \\
\text { tindak lanjut }\end{array}$ & $\begin{array}{l}\text { - Sebaiknya LSM yang bergerak di bidang konservasi bekerja } \\
\text { sama dengan pemerintah, dan bagaimana agar pengusaha } \\
\text { mendapatkan insentif dengan diadakannya kegiatan dalam } \\
\text { bidang biodiversity } \\
\text { - } \\
\text { Penyegaran/pelatihan tentang biodiversity dengan melibatkan } \\
\text { IUPHHK, pemerintah, LSM di bidangnya } \\
\text { - Pemerintah + NGO yang bergerak di bidang konservasi } \\
\text { (berkolaborasi) untuk sosialisasi ttg kawasan konservasi dan } \\
\text { pendampingan ke praktisi pelaksanaannya } \\
\text { - Pemerintah dan NGO (pihak ketiga yang independen) } \\
\text { memfasilitasi penguatan kapasitas pengusaha dalam } \\
\text { melakukan pengelolaan kawasan hutan yang memiliki nilai } \\
\text { konservasi/biodiversity yang tinggi } \\
\text { - Capacity Building pelaku, dibangun pasar yang menguntungkan } \\
\text { buat produk non kayu dari hutan } \\
\text { - Sosialisasi manajemen ekosistem kepada pemerintah, } \\
\text { pengusaha, masyarakat dan pembuatan petunjuk praktis } \\
\text { tentang manajemen ekosistem bagi pengusaha } \\
\text { - Pemanfaatan litbang, aturan tidak berbenturan sehingga perlu } \\
\text { revisi, training } \\
\text { - Sosialisasi tingkat keberhasilan ke para pihak } \\
\text { Diperlukan pemahaman yang sama mengenai biodiversity } \\
\text { antara pengusaha dan pemerintah, LSM di bidang konservasi } \\
\text { bisa memfasilitasi } \\
\text { - Memberikan penjelasan kepada pemilik mengenai guideline } \\
\text { biodiversity } \\
\text { - Lokakarya tentang biodiversity untuk pengusaha maupun untuk } \\
\text { pemerintah yang berhubungan dengan konservasi } \\
\text { C \& yang seragam antar lembaga sertifikasi }\end{array}$ \\
\hline
\end{tabular}




\begin{tabular}{|c|c|}
\hline $\begin{array}{l}\text { Pedoman Umum } \\
\text { (Kata Kunci) }\end{array}$ & Diskusi \\
\hline & $\begin{array}{l}\text { - Menyampaikan hasil ujicoba dan mencari masukan sebelum } \\
\text { menjadi aturan } \\
\text { - } \text { "Sign Positive Willingness" dari IUPHHK untuk melakukan ujicoba } \\
\text { - } \text { Testing di IUPHHK dilakukan secara kolaborasi: NGO - } \\
\text { Pemerintah - IUPHHK } \\
\text { - Pemerintah dan NGO bidang konservasi memberi pelatihan \& } \\
\text { lokakarya masalah konservasi dan menyusun juknis \& juklak } \\
\text { panduan kerja di lapangan } \\
\text { - In house training/okakarya di IUPHHK, yang dibantu/didanai } \\
\text { oleh pemerintah } \\
\text { - Pengukuhan hukum/perundang-undangan dalam penetapan } \\
\text { kebijakan antara pusat dan daerah }\end{array}$ \\
\hline $\begin{array}{l}\text { 9. Komentar untuk } \\
\text { isu strategis }\end{array}$ & $\begin{array}{l}\text { Pak Soeyitno (KKS) } \\
\text { - } \quad \text { Ujicoba yang mau dilakukan oleh siapa? IUPHHK sendiri atau } \\
\text { pemerintah atau tim khusus. } \\
\text { Pak Tetra (WWF) } \\
\text { Harapannya IUPHHK memberikan in kind kepada tim } \\
\text { Pak Petrus (CIFOR) } \\
\text { - SDM tidak merata sehingga pemahaman konservasi lemah } \\
\cdot \quad \text { Kalau PBB dihapus camat tentu akan menanyakan, gimana? }\end{array}$ \\
\hline
\end{tabular}




\section{Presentasi Kelompok dan Diskusi Pleno}


tis

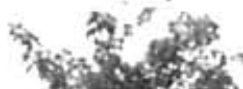

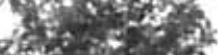

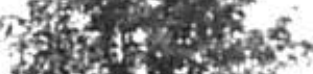

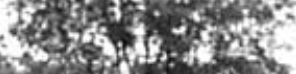

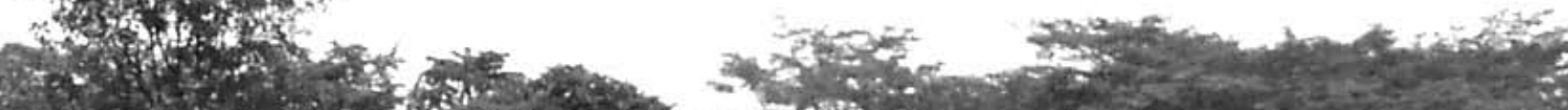

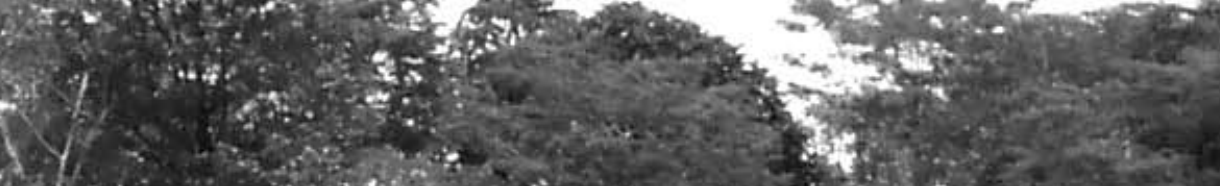

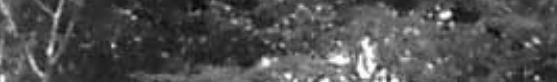

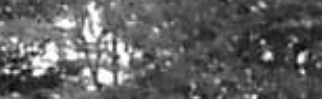

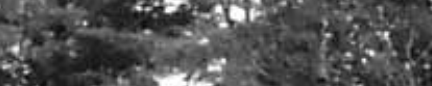

2.

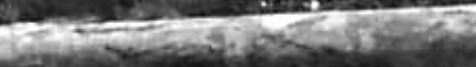

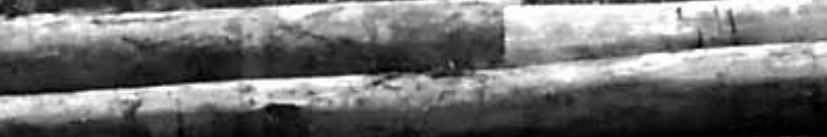

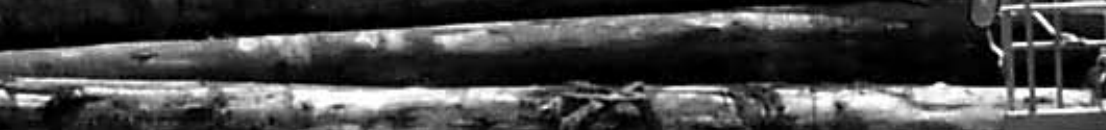

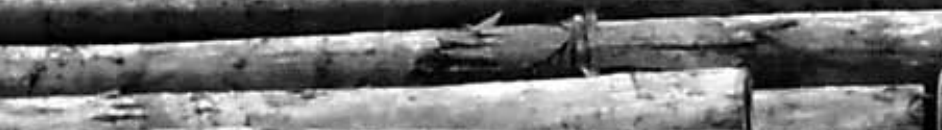

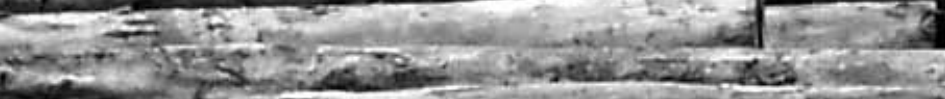

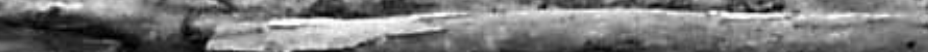

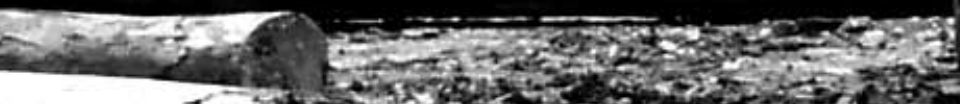

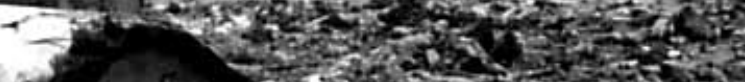
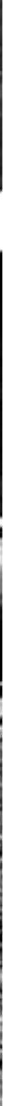

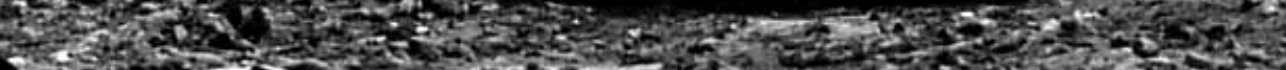

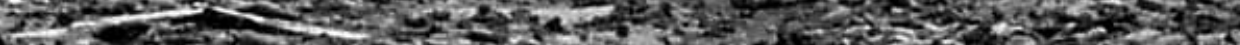
Pि 3 6.3.

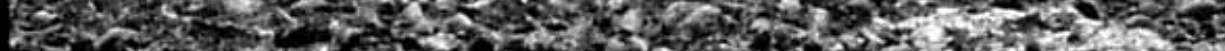

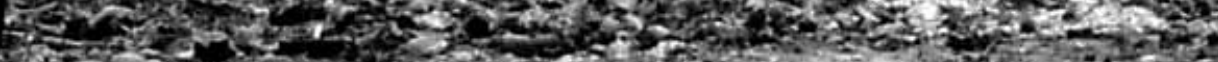

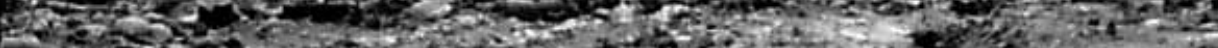

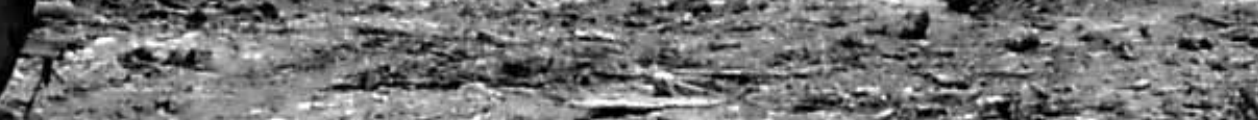
I.

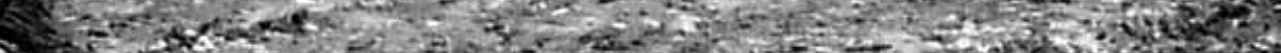
W.

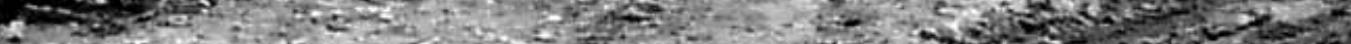

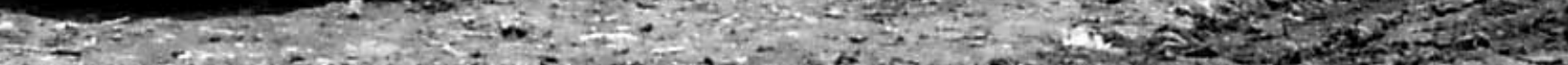

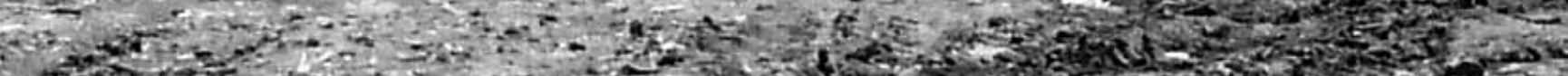

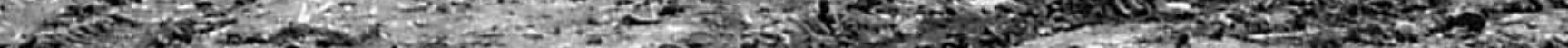

\section{Kegiatan di tempat penimbunan kayu hasil tebangan (Foto oleh Hari Priyadi)}




\section{Kelompok 1. RIL dan Pembelajarannya}

\section{Presentasi}

Presentasi disampaikan oleh Yosef Ruslim (TNC-Unmul). Presenter memulai dengan menjelaskan bagaimana proses diskusi serta komposisi anggota diskusi yaitu: Dinas Kehutanan, IUPHHK/Perusahaan, Akademik/Universitas, Lembaga International/ Riset, Litbang Kehutanan, dan NGO. Presentasi kelompok dan proses diskusi (tanya jawab) pleno difasilitasi oleh Petrus Gunarso (CIFOR).

\section{Ketertarikan dan keuntungan dalam mengimplementasikan RIL?}

- Memperoleh sertifikat (tuntutan ISO, dan lain-lain)

- Ada support awal melalui kerjasama luar (TFF, CIFOR, GTZ, KKS, dan lainlain)

- Manfaat ekologi, terutama meminimalkan dampak fisik

- Kekuatan eksternal (antara lain pasar)

- Kekuatan internal (komitmen rimbawan) terhadap keterjagaan dan kelestarian lingkungan melalui SFM

- Implementasi RIL merupakan penyempurnaan implementasi TPTII secara baik, benar dan konsisten

- Porsi RIL tinggi dalam penilai SFM (sukses RIL 30\% dari SFM)

- Unggul dalam kegiatan logging

- Kemungkinan basis bisnis non kayu dan jasa lingkungan, sosial, dan lain-lain

\section{Insentif yang diterima setelah melaksanakan RIL dan sertifikat} SFM

- Belum ada apresiasi dari birokrasi (Perijinan, Perpajakan, TUK, dan lain-lain)

- Tidak ada premium price

- Manfaat finansial dan ekologi bagi perusahaan

- Harus ada self assessment

- Memilih sendiri sistem silvikultur

- Ada sertifikat keahlian yang diakui luas (operator) APHI/Persaki 


\section{Masalah-masalah yang dihadapi dalam upaya melaksanakan RIL}

- Teknis (mengubah kebiasaan/attitude)

- Sumberdaya manusia

- Kendala eksternal dan internal

- Kurangnya dukungan dari stakeholder

- Kepastian (regulasi, kawasan, perijinan, dan lain-lain)

- Komitmen dari perspektif SFM dari owner dan top management

\section{SK No. 274/VI-PHA/2001 mengenai keharusan IUPHHK melaksanakan RIL}

- Sosialisasi yang minim tentang surat edaran ini

- Di birokrasi daerah (Dishut kabupaten) umumnya baru terbentuk dan masih dalam proses konsolidasi

- Banyak yang belum tahu

\section{Rekomendasi}

\section{Perusahaan (owner)}

- Harus ada komitmen, dukungan serta visi dan misi dalam membangun hutan lestari

- Keahlian Teknis RIL sebagai salah satu syarat rekruitmen

- Sosialisasi dan dissemininasi keuntungan/kelebihan RIL (finansial, ekologi, pasar, dan lain-lain) kepada owner

- Kegiatan operasional tidak dikontrakkan

- Perlu pendampingan/kerjasama dan pengembangan jaringan untuk ujicoba RIL

- Peningkatan SDM dan teknis dalam implementasi RIL

- Pembinaan moral secara kontinyu dan konsisten

- Inventarisasi potensi (kayu) secara akurat

- Reward dan insentif untuk karyawan yang mengimplementasikan RIL

\section{Pemerintah (birokrasi)}

- Membentuk regulasi yang konsisten dan menjamin kepastian (hukum, kawasan)

- Sosialisasi dan dissemininasi keuntungan/kelebihan RIL (finansial, ekologi, pasar, dan lain-lain)

- Peningkatan SDM kehutanan dalam SFM khususnya RIL

- Kebijakan untuk self assessment

- Ada insentif, reward, apresiasi untuk perusahaan yang telah menjalankan SFM dengan baik (premium price, perpajakan, perijinan, birokrasi TUK, JPT, dan lain-lain)

- Sinkronisasi kebijakan pusat dan daerah (kewenangan, pengelolaan kawasan, tata ruang, dan lain-lain)

- $\quad$ SFM (termasuk RIL) menjadi persyaratan memperoleh RKT

- Mengembangkan jaringan dengan NGO dan lembaga internasional yang komitmen SFM 
- $\quad$ Fasilitasi dan mediasi untuk pengembangan RIL

- Transformasi kebijakan untuk tata kelola hutan (khususnya IUPHHK) yang baik, benar dan bersih dari KKN

- Kebebasan dalam memilih sistem silvikultur sesuai kondisi

\section{Lain-lain (NGO, Akademik, Donor, dan lain-lain)}

- Fasilitasi dan mediasi tidak hanya IUPHHK tetapi juga Birokrat

- Sosialisasi, disseminasi dan promosi kepada semua stakeholder terus menerus

- Mendorong implementasi reward, insentif, premium price, apresiasi dan akses pasar

- Kerjasama diperluas untuk semua IUPHHK dan akses yang variatif

- Mengembangkan plot permanen dan pusat Diklat

\section{Tanggapan}

Selesai presentasi, moderator langsung meminta peserta untuk melakukan klarifikasi, pertanyaan dan masukan. Tanggapan peserta dan klarifikasi dari kelompok serta moderator adalah sebagai berikut:

\section{Syahrani (PT KBT)}

Rekomendasi kelompok 1 terkait poin tindak lanjut bagi IUPHHK, birokrasi dan akademisi, sebaiknya jangan memberi masukan uang ke birokrasi yang prakteknya akan memberi beban baru bagi pengusaha, terutama seperti RIL sebagai kewajiban persyaratan pengurusan RKT.

\section{Bondan (PT Inhutani II-APHI)}

Sertifikasi ada 2 yaitu complimentary dan mandatory. Jika kebijakan seperti sertifikasi memang mandatory sebaiknya dilakukan secara bertahap karena SFM perlu proses

\section{Ayi Suyana (BPPK Samarinda)}

RIL bukan suatu kebijakan tapi alat dalam operasional pengusahaan hutan yang dinilai murah, mudah, dan ramah lingkungan

\section{Perwakilan dari IUPHHK}

- Ikut keberatan jika RIL sebagai persyaratan. Selama ini IUPHHK kewalahan dengan banyaknya 'kunjungan' dan berbagai tim yang tidak terkontrol. Rekomendasi sebaiknya lebih kepada kebijakan pusat dan daerah yang seringkali tidak sinkron

- $\quad$ TPTII sudah ada RIL, mengapa tidak pakai TPTII saja dengan memperketat pengawasannya?

- $\quad$ SFM ini mandatorinya ada dari SK Menhut, mengapa tidak ini saja lebih dikonkretkan di tingkat daerah terutama progress dan monitoringnya sehingga tidak lagi banyak beban seperti bina desa, TPTII, dan lain-lain. Tim bisa lebih disederhanakan dalam satu tim SFM 


\section{Kresno (CIFOR)}

- IUPHHK tanpa RIL juga bisa memperoleh RKT, padahal SK Menteri tentang RIL sudah ada semenjak tahun 2001

- $\quad$ RKT yang benar merupakan salah satu bagian dari SFM karena dalam RKT mengatur kelayakan potensi dan luasan.

\section{Petrus Gunarso (Moderator)}

- $\quad$ Sepertinya RIL dan RKT menjadi momok, mengapa? Padahal jika kita komitmen SFM dimana ada keterjaminan kelestarian, pemerintah juga akan memudahkan dalam proses evaluasi dan monitoringnya. Di sisi lain pemerintah seringkali meminta bagaimana pengusaha melakukan SFM. Semestinya regulasi dengan pebisnis bagaimana memperoleh keuntungan yang tidak kebablasan. Dalam forum ini kita semua berkeinginan untuk melakukan bisnis yang baik dengan SFM sebagai komitmen bersama sehingga semua memperoleh keuntungan termasuk generasi yang akan datang

- Aturan yang ada diterapkan dengan baik-baik, semangatnya adalah SFM jika memang kita ingin usaha di bidang kehutanan. SFM sudah seharusnya menjadi komitmen, jika tidak jangan usaha di sektor kehutanan.

- Kita sekarang tengah menuju ke good forest governance

- Darikalangan pengusaha RIL melihatnya sebagai regulasibaru, kecenderungannya jangan sampai ini menjadi regulasi baru. Jikapun ini menjadi sebuah regulasi ini sebenarnya untuk kepentingan semua dan bukan hanya untuk pemerintah.

- Ada pengalaman menarik anggota DPR pernah meminta peta pohon dari IUPHHK, urgensinya bagaimana? Tetapi ini menarik dalam kerangka transparansi menuju tata kelola hutan yang lebih baik, asal ujung-ujungnya bukan untuk duit.

- Pengalaman di USA, sebuah negara bagian membuat dua kebijakan yang berbeda untuk proses evaluasi dan monitoring. Di Negara bagian California sangat birokratis dengan aturan seperti RKT yang tebal dan dokumen yang harus lengkap. Sedangkan negara bagian di Washington proses dan biaya pengaturan dokumen semacam RKT cukup dua lembar, tetapi dengan 2 lembar itulah kontrol diperketat. Kontrol pengecekan dilakukan secara acak, tetapi jika ternyata ketahuan sanksinya sangat berat sehingga kebanyakan perusahaan sangat berhati-hati. 


\section{Kelompok 2. \\ Sertifikasi dan Keanekaragaman Hayati (Kehati)}

\section{Presentasi}

Presentasi dipimpin oleh Joko Sarjito (PT SLJ II), diawali dengan perkenalan presenter dan uraian singkat tentang topik dan dinamika selama proses diskusi di kelompok 2.

\section{Kenapa perlu keanekaragaman hayati}

- Nilai kayunya hanya 5\% dari hutan produksi

- Panduan ITTO membantu menilai nilai keanekaragaman hayati di hutan produksi

- Panduan membantu untuk melindungi dan memanfaatkan kehati di hutan produksi

- Konsep ekologi satwa belum banyak dipahami oleh IUPHHK sehingga kebutuhan konservasi di hutan produksi muncul belakangan, perlu sosialisasi dan pendampingan

- IUPHHK hanya mendaftar/mencatat potensi kayu dan belum memperhatikan biodiversity sehingga perlu ada regulasi khusus

- IUPHHK sudah menerapkan kawasan plasma nutfah (300 ha/blok tebangan), apakah ini bisa dianggap sebagai 'zona konservasi' atau cikal bakal konservasi biodiversity di hutan produksi

- Masyarakat banyak yang belum memahami peraturan perundang-undangan perlindungan hidupan liar

- Panduan harus bisa menjadi pelengkap peraturan yang sudah ada di hutan produksi untuk menilai biodiversity

- Sumalindo II punya 75.000 ha (dari 2000 ha) kawasan lindung (kawasan yang memiliki HCVF)

- Kawasan konservasi di hutan produksi sebaiknya bisa juga dimanfaatkan biodiversity-nya, misalnya oleh masyarakat, hal ini juga merupakan bagian dari proses sertifikasi.

- NTFP lebih difokuskan untuk dimanfaatkan masyarakat, namun dalam menerapkan pemanfaatan biodiversity di hutan produksi perlu kehati-hatian. 


\section{Keanekaragaman Hayati diperlukan:}

- Akses dan Pemanfaatan

- Keanekaragaman hayati tidak hanya di kawasan konservasi tetapi di kawasan produksi malah bisa punya nilai konservasi

- Pengelolaan hutan sebaiknya berdasarkan ekosistem tidak berdasarkan fungsi hutan sehingga diperlukan komitmen dari pemerintah/peraturan dan pengusaha

\section{Kebutuhan Pengusaha:}

Perlu sosialisasi dan pemahaman yang konkret serta komprehensif untuk berbagai istilah konservasi dan keanekaragaman hayati antara lain:

- Ekologi satwa

- Plasma nutfah

- Koridor satwa

- Zona penyangga (buffer zone)

- Kebun bibit

- $\mathrm{HCVF}$

- Konservasi

- Keanekaragaman hayati

- Pemanfaatan yang berkelanjutan

- Kebutuhan vs. Formalitas

- Pemanfaatan kawasan lindung

- Internalisasi sampai dengan level operasional

- Konvensi (CBD, CITES, dan lain-lain). Bagaimana hubungannya dengan aturan?

\section{Kebutuhan Pemerintah:}

- Aturan/kebijakan tidak parsial (terkotak-kotak) yang mengakibatkan kompetisi antara Produksi vs. Konservasi

- Pengembangan insentif dan disintensif terhadap pengusaha yang kelola konservasi, antara lain:

- Pajak/pembebasan PBB oleh Pemda/PAD

- JPT, Performance

- $\quad$ SDM tidak merata sehingga pemahaman konservasi lemah

\section{Saran/masukan untuk insentif yang diharapkan pengusaha}

- Inventarisasi kehati

- Kepastian berusaha (perpanjangan IUPHHK)

- $\quad$ Prosedur inventarisasi yang efisien termasuk aspek ekologi

- Penyederhanaan jalur birokrasi pengurusan ijin

- Kemudahan dalam perijinan

- Insentif untuk mengelola dan memelihara kawasan HCVF

- Pajak PBB, JPT berdasarkan performance pengelolaan kehati

- Diberikan hak untuk memanfaatkan kawasan lindung (biodiversity)

- $\quad$ Ijin JPT keluar lebih cepat 
- $\quad$ SFM menjadi keharusan bagi IUPHHK oleh pemerintah (Dephut)

- Konservasi menjadi bagian dari SFM, maka pemerintah (Dephut) harus:

- Memberi insentif pembebasan beban finansial untuk kawasan konservasi (PBB)

- Memberikan juknis secara komprehensif tentang pengelolaan kawasan konservasi dan kawasan lindung

- Kemudahan administrasi di daerah

- Pembinaan/pengawasan dengan SDM yang profesional

- Pengurangan/diskon dari biaya pengurusan ijin sesuai nilai biodiversity

- Pengakuan bahwa perusahaan sudah melakukan kegiatan kehati

- Kepastian hukum kawasan yang dikonservasi dari pemerintah

- Pemerintah memberikan kompensasi kepada pemerintah kecamatan/kabupaten atas berkurangnya PAD

- Dialog antara pemerintah pusat dan daerah tentang pembebasan pajak/PBB

- Adanya pemahaman yang sama pemerintah pusat dan daerah tentang penarikan PBB dari IUPHHK agar dimanfaatkan oleh pengusaha

\section{Rekomendasi dan Tindak Lanjut}

- Sebaiknya LSM yang bergerak di bidang konservasi bekerja sama dengan pemerintah, dan bagaimana agar pengusaha mendapatkan insentif dengan diadakannya kegiatan dalam bidang biodiversity

- Penyegaran/pelatihan tentang biodiversity dengan melibatkan: IUPHHK, pemerintah, LSM di bidangnya

- Pemerintah dan NGO yang bergerak di bidang konservasi (berkolaborasi) untuk sosialisasi tentang kawasan konservasi dan pendampingan ke praktisi pelaksanaannya

- Pemerintah dan NGO (pihak ketiga yang independen) memfasilitasi penguatan kapasitas pengusaha dalam melakukan pengelolaan kawasan hutan yang memiliki nilai konservasi/biodiversity yang tinggi

- Capacity building pelaku, dibangun pasar yang menguntungkan buat produk non kayu dari hutan

- Sosialisasi manajemen ekosistem kepada pemerintah, pengusaha, masyarakat dan pembuatan petunjuk praktis tentang manajemen ekosistem bagi pengusaha

- Pemanfaatan hasil-hasil penelitian dan pengembangan, sehingga aturan tidak berbenturan sehingga perlu revisi, training dan lain-lain.

- Sosialisasi tingkat keberhasilan ke para pihak

- Diperlukan pemahaman yang sama mengenai biodiversity antara pengusaha dan pemerintah, LSM di bidang konservasi bisa memfasilitasi

- Memberikan penjelasan kepada pemilik mengenai guideline biodiversity

- Lokakarya tentang nilai penting biodiversity untuk pengusaha maupun untuk pemerintah yang berhubungan dengan konservasi

- Kriteria dan indikator yang seragam antar lembaga sertifikasi

- Menyampaikan hasil ujicoba dan mencari masukan sebelum menjadi aturan

- "Sign Positive Willingness" dari IUPHHK untuk melakukan ujicoba

- $\quad$ Testing di IUPHHK dilakukan secara kolaborasi antar NGO - Pemerintah IUPHHK 
- Pemerintah dan NGO bidang konservasi memberi pelatihan dan lokakarya masalah konservasi dan menyusun petunjuk teknis dan petunjuk pelaksanaan sebagai panduan kerja di lapangan

- In house training/lokakarya di IUPHHK, yang dibantu/didanai oleh pemerintah

- Pengukuhan hukum/perundang-undangan dalam penetapan kebijakan antara pusat dan daerah

\section{Tanggapan}

Selesai presentasi, moderator langsung meminta peserta untuk melakukan klarifikasi, pertanyaan dan masukan. Tanggapan peserta dan klarifikasi dari kelompok serta moderator adalah sebagai berikut:

\section{Adit (LEI)}

Untuk rekomendasi C \& I yang seragam antar lembaga sertifikasi, faktanya asesor berbeda-beda dan dalam hal ini user memiliki hak untuk menolak

\section{Nurcahyo Adi (WWF)}

- Diskusinya sudah banyak, semangatnya kita ingin melihat bahwa aturan itu tidak selamanya berpihak pada hal-hal yang praktis, tetapi juga dari temuan yang didasarkan dari proses ilmiah. Tidak perlu ada dikotomi antara sesuatu yang ilmiah dengan pengetahuan praktis praktisi di lapangan. Para praktisi lapangan seringkali menganggap sesuatu yang bersifat ilmiah adalah sesuatu yang mengawang-awang.

- Tentang keanekaragaman hayati dan kelestariannya, aturannya sudah ada dan semua yang disampaikan juga sudah tidak asing. Jika ingin membumikan hal tersebut dapat mensinergikan hasil-hasil dari berbagai seminar, lokakarya dan sejenisnya yang cukup banyak. 
Perumusan Hasil dan Rekomendasi 
xys.

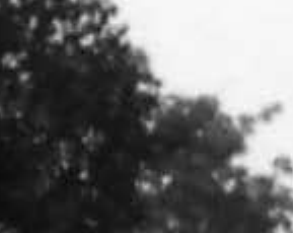

$x^{5}+2^{2}+x^{2}$

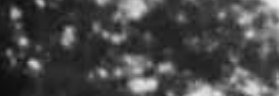

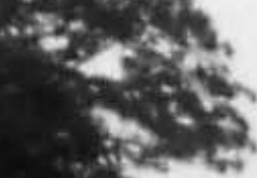

$0, x y=-45$

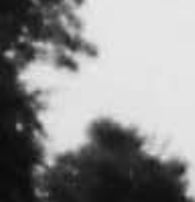

4.

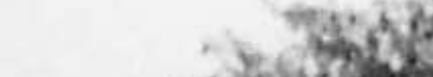

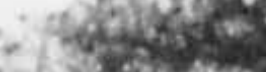
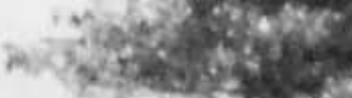

$y^{2}+x^{2}=$

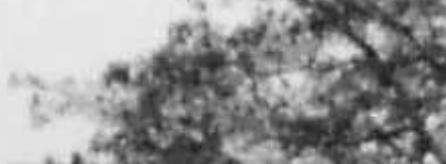

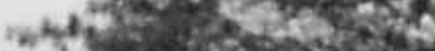

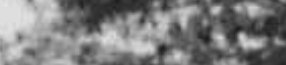

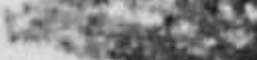

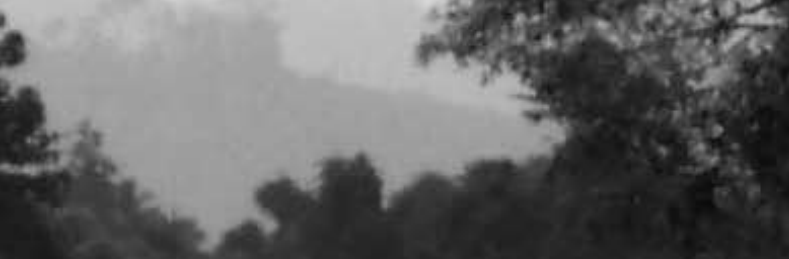

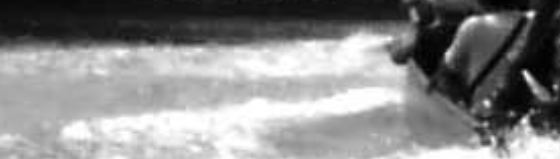

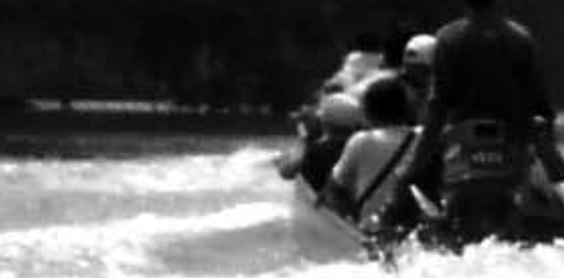

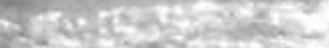

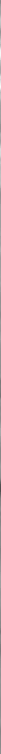

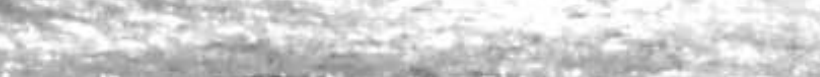

\section{Bersama bahu membahu dalam menuju kehidupan yang lebih baik (Foto oleh Tim MRF)}




\section{Proses}

Proses penyusunan rumusan dan rekomendasi hasil-hasil lokakarya dilakukan secara bertahap. Berbagai temuan dan catatan penting selama berlangsungnya kegiatan didokumentasikan oleh Prof. Dr. M. Agung Sardjono sekaligus menyusun draft rumusan dan rekomendasi.

Draft rekomendasi yang telah tersaji selanjutnya dicermati dan dibahas bersama oleh tim perumus yang terdiri dari berbagai unsur yang dipandang cukup representatif dari komposisi semua peserta.

Ketua:

Anggota tim perumus yaitu:

Prof. Dr. Mustofa Agung Sardjono (Staf Pengajar Fakultas Kehutanan Universitas Mulawarman/Direktur Center for Social Forestry)

Anggota:

1. Ir. Ayi Suyana, M.P (Balai Penelitian dan Pengembangan Kehutanan (BP2K) Kalimantan)

2. Ir. Bondan, P. H (Asosiasi Pengusaha Hutan Indonesia (APHI) Kalimantan Timur)

3. Prof. Dr. Ir. H. Soeyitno Soedirman, M. Agr (Kelompok Kerja Sertifikasi (KKS) APHI Kalimantan Timur)

4. Dr. Ir. Petrus Gunarso (Koordinator Program Malinau Research Forest (MRF) CIFOR)

5. Dr. Ir. H. Tetra Yanuariadi, M.Sc.(Koordinator Nasional Program Forest Partnership (TBI Indonesia-CIFOR-WWF)

6. Ir. Aditya Bayunanda (Program Manajer Manajemen Proyek Lembaga Ekolabel Indonesia (LEI)

7. Akhmad Wijaya, S.Hut (Direktur Yayasan BIOMA Samarinda)

8. Ardiansyah (Persatuan Masyarakat Adat/Pema Paser)

9. Ir. Hari Priyadi, M.Sc (CIFOR)

10. Ir. Alfan Subekti, M.Sc (Tropenbos)

11. Ir. Agung Prasetyo, M.Sc (CIFOR) 


\section{Hasil}

Hasil finalisasi rumusan sekaligus rekomendasi dari lokakarya ini adalah sebagai berikut:

Kami 60 orang peserta "Lokakarya Menuju Tata Kelola Hutan yang Baik" berasal dari para pihak kehutanan yaitu kalangan pengusaha hutan (pemegang IUPHHK) di Kalimantan Timur, unsur Pemerintah/Birokrasi (Pusat, Provinsi, Kabupaten/ Kota), Akademisi, Organisasi Non-Pemerintah (LSM), Forum Informal (Kelompok Kerja) dan Lembaga Internasional setelah mendengarkan arahan dan pengalaman pembelajaran, berdiskusi serta melakukan curah pendapat selama dua hari penuh tentang tiga isu penting terkait (1) Tata Kelola Hutan yang baik; (2) Pembalakan Hutan Ramah Lingkungan (RIL); serta (3) Sertifikasi Hutan, Keanekaragaman Hayati dan pemanfaatannya secara lestari pada Hutan Produksi memperoleh pembelajaran dan menghasilkan beberapa kesimpulan penting serta bersepakat untuk memberikan rekomendasi tindak lanjut, sebagai berikut:

\section{Kesimpulan}

1. Sumberdaya hutan di Indonesia pada umumnya dan di Kalimantan Timur pada khususnya dalam beberapa tahun terakhir telah mencapai laju kerusakan per tahunnya yang sangat mengkhawatirkan demi kelangsungan fungsi dan manfaatnya bagi seluruh masyarakat di tingkat lokal hingga global (sekitar 3,6 juta hektar secara Nasional atau sekitar 300.000 hingga 500.000 hektar di Kalimantan) menuntut tata kelola hutan yang baik.

2. Tata kelola hutan yang baik (good forest governance), yaitu pola/mekanisme hubungan kelembagaan dalam rangka pengurusan dan pengelolaan sumberdaya hutan yang menjalankan prinsip-prinsip supremasi hukum, akuntabilitas, transparansi, dan demokratisasi serta yang tidak kalah pentingnya adalah partisipasi aktif para pihak kehutanan.

3. Partisipasi aktif para pihak kehutanan dimulai sejak pengambilan keputusan/ perumusan kebijakan yang menjadi kewenangan Pemerintah (Pusat, Provinsi, Kabupaten/Kota) hingga pelaksanaannya di lapangan oleh para pemegang konsesi hutan atau pelaku usaha kehutanan guna tercapainya pengelolaan hutan yang lestari.

4. Pengelolaan hutan yang lestari (sustainable forest management) oleh para pengusaha hutan dapat diwujudkan antara lain dengan pelaksanaan pembalakan 
hutan ramah lingkungan (reduced impact logging) serta keikutsertaan dalam skema sertifikasi pengelolaan hutan lestari.

5. Berdasarkan teori dan juga pengalaman beberapa IUPHHK, RIL memang memerlukan beberapa kondisi antara lain kapasitas sumberdaya manusia yang memadai dan dukungan manajemen. Akan tetapi RIL mampu memberikan keuntungan ekonomi langsung dan tidak langsung antara lain memperbaiki kondisi tegakan tinggal/permudaan (pengurangan biaya pembinaan), kejelasan wilayah kelola dengan masyarakat, dan keberlangsungan fungsi ekologis (hidrorologis dan keanekaragaman hayati). Bahkan apabila RIL dilaksanakan dengan konsisten, maka sebagian dari kriteria dan indikator sertifikasi pengelolaan hutan lestari mampu dipenuhi.

6. Khusus mengenai keanekaragaman hayati diketahui bahwa pada dasarnya nilai ekonomi kayu adalah porsi dari fungsi dan manfaat sumberdaya hutan (besarnya tidak lebih dari 5\%), adapun sisanya diperoleh dari Hasil Hutan Non-Kayu (Non-Timber Forest Products/NTFPs) dan jasa lingkungan. Oleh karenanya data mengenai keanekaragaman hayati (flora dan fauna) merupakan hal yang penting, termasuk dalam mempersiapkan diri guna pelaksanaan implementasi pengelolaan hutan berbasis sumberdaya (resource based forest management).

7. Disamping adanya keuntungan pelaksanaan RIL, pengalaman terkait yaitu uji coba sistem silvikultur Tebang Pilih Tanam Indonesia Intensif (TPTIII) menunjukkan mampu meningkatkan produktivitas hutan dalam kurun waktu (daur) yang lebih pendek. Sebagaimana RIL, maka TPTIII juga menuntut adanya dukungan top manajemen serta ketersediaan data/informasi unit manajemen. Selain itu aspek insentif dari pemerintah khususnya juga sangat diperlukan.

8. Keberhasilan memperoleh Sertifikasi Pengelolaan Hutan Lestari memerlukan persiapan yang matang dan relatif berjangka panjang, yang pada dasarnya juga sangat dipengaruhi oleh dukungan penuh dari top manajemen. Meskipun demikian guna memenuhi keseluruhan kriteria dan indikator sertifikasi, aspekaspek eksternal khususnya yang bersifat prasyarat mutlak seperti persoalan kepastian lahan yang notabene menjadi kewenangan Pemerintah harus pula dipecahkan.

9. Keinginan para pengusaha hutan di Kalimantan Timur, khususnya para rimbawan yang bekerja didalamnya, untuk mempersiapkan diri dan melaksanakan sertifikasi pengelolaan hutan yang lestari telah ditunjukkan dengan antusiasme untuk mendukung dan sebaliknya juga memperoleh dukungan Kelompok Kerja Sertifikasi (KKS) Kalimantan Timur, yang merupakan forum bersama para pihak kehutanan (berdiri tahun 2001).

10. Meskipun dalam tiga tahun terakhir KKS Kalimantan Timur tidakaktifmelakukan kegiatan, akan tetapi hingga saat ini tetap bersedia untuk merealisasikan visi dan misinya guna membantu mewujudkan pelaksanaan sertifikasi pengelolaan hutan lestari, sejauh masih diperlukan dan memperoleh dukungan serta fasilitasi dari anggota serta para pihak lainnya.

11. Belum banyaknya pengusaha hutan yang mempersiapkan dan mendaftarkan diri untuk mengimplementasikan RIL dan mengikuti sertifikasi pengelolaan hutan lestari dikarenakan beberapa faktor (internal dan eksternal) a.l. belum luasnya sosialisasi peraturan perundangan terkait (a.l. SE Dirjen PHA No. 274/VI- 
PHA/2001 tentang Keharusan IUPHHK melaksanakan RIL), masih terbatasnya pengetahuan praktisi dan birokrasi tentang RIL, ketidakpastian usaha (ditinjau dari aspek kebijakan yang selalu berubah) dan belum banyaknya contoh konkret keuntungan berusaha setelah sertifikasi/insentif (antara lain self-assessment, premium price).

\section{Rekomendasi}

1. Pengetahuan dan kebijakan RIL, HCVF ataupun sertifikasi secara umum perlu disebarluaskan tidak hanya kepada para pengusaha hutan tetapi juga aparat melalui berbagai cara, seperti pelatihan, lokakarya, agar tercapai kesepahaman dan kesamaan persepsi antar para pihak kehutanan.

2. Sebaliknya pihak pemerintah dan juga manajemen perusahaan perlu mengupayakan berbagai bentuk insentif bagi perusahaan-perusahaan kehutanan yang secara serius melaksanakan RIL, penetapan HCVF dan mencapai pengusahaan hutan yang lestari.

3. Rencana uji coba Panduan ITTO dalam konservasi keanekaragaman hayati pada hutan produksi merupakan proses 'bottom-up' yang perlu memperoleh dukungan dari para pihak kehutanan.

4. Pemerintah (Pusat, Provinsi, Kabupaten/Kota) diharapkan tidak membuat penerapan pengelolaan hutan lestari (termasuk RIL dan HCVF) yang menimbulkan beban finansial dan administrasi yang lebih tinggi/berat kepada para pengusaha/pengelola hutan dan sebaliknya justru membuat prosedur lebih efektif dan efisien.

5. Agar tercapai pengelolaan hutan lestari Pemerintah Pusat, Provinsi, Kabupaten/ Kota perlu melakukan sinkronisasi peraturan/kebijakan, tidak hanya dalam hal pengelolaan sumberdaya hutan tetapi juga yang terpenting (dan menjadi prasyarat bagi kepastian kawasan) menyangkut penataan ruang.

6. Perlu dipertimbangkan oleh Pemerintah mengenai kemungkinan kebijakan/ peraturan bagi para pemegang IUPHHK untuk dapat mengusahakan tidak hanya kayu tetapi juga NTFP dan juga jasa lingkungan pada unit manajemen yang sama.

7. Organisasi Non-Pemerintah, Lembaga Penyangga Internasional serta Lembaga Penelitian dan Akademisi diharapkan dapat memfasilitasi para pihak lainnya khususnya para pengusaha hutan untuk implementasi RIL dan persiapan pelaksanaan sertifikasi pengelolaan hutan lestari.

8. Dalam rangka mendukung seperti keinginan tersebut di atas perlu dikembangkan jaringan kerja (network), sehingga untuk itu bentuk-bentuk kemitraan seperti halnya KKS Kalimantan Timur diharapkan dapat aktif/diaktifkan kembali (revitalisasi dan restrukturisasi).

Balikpapan, 22 Juni 2006

Tim Perumus 


\section{Penutup}




\title{
Sambutan Ketua Penyelenggara sekaligus Penutupan
}

\author{
Petrus Gunarso \\ CIFOR
}

Selamat sore dan salam sejahtera bagi kita semua,

Yth. Para Anggota APHI/KKS dan undangan lainnya yang berbahagia serta Teman-teman di CIFOR, Tropenbos dan WWF Indonesia.

Puji syukur bahwa kita akhirnya telah sampai pada sesi akhir kegiatan berupa penutupan.

Ucapan terima kasih khususnya kepada semua peserta yang mengikuti lokakarya sampai selesai dengan antusias. Kesuksesan dalam kegiatan ini tidak bisa tercapai tanpa kerjasama dan partisipasi yang baik dari kita semua. Untuk itu ucapan terima kasih dan penghargaan yang tulus kami sampaikan kepada:

- Tropenbos Internasional Indonesia Program sebagai tuan rumah bagi penyelenggaraan kegiatan ini

- WWF Forest Partnership dan WWF Nusa Hijau sebagai donatur

- Kelompok Kerja Sertifikasi (KKS)

- Departemen Kehutanan (Pusat, Provinsi, Kabupaten dan BPK Samarinda)

- Yayasan Bioma untuk bantuan proses

Follow up dari kegiatan dan hasil-hasil serta rumusan diskusi ke depan tentu saja akan disampaikan kepada semua peserta, selain tentunya pemerintah. Mudahmudahan dalam waktu yang tidak lama dapat dikirim segera berupa prosiding lokakarya. Untuk itu mohon alamat jangan keliru untuk pengiriman hasil-hasil lokakarya yang sudah kita laksanakan.

Untuk masukan dan kritik diharapkan untuk segera disampaikan sebagai bahan perbaikan, karena CIFOR, WWF dan TBI ikut dalam proses pembuatan panduan. Demi kebaikan dan penyempurnaan panduan tersebut hasil-hasil ini akan disampaikan juga ke Dephut, Dinas Kehutanan Provinsi, Kabupaten dan lembagalembaga terkait lainnya serta seluruh partner. 
Masalah-masalah pengusaha dan kesulitan seperti dalam pengurusan dokumen, pengangkutan, birokrasi, dan lain-lain, hal tersebut harus kita sadari bahwa diskusi ini berguna untuk memperkuat kebersamaan untuk mengatasi kesulitan tersebut. Kayu kita di pasaran masih cukup besar dan potensial. Harga kayu tropis akhir-akhir ini cukup meningkat semoga hal ini menjadi momentum untuk peningkatan usaha sektor kehutanan yang lebih baik.

Apa yang telah disampaikan tadi beserta hasil-hasil yang telah disepakati bersama dalam rumusan merupakan hasil kita semua. Dengan memanjatkan puji syukur kepada Tuhan Yang Maha Esa maka dengan ini saya nyatakan lokakarya kita pada dua hari ini ditutup. Terima kasih. 


\section{Lampiran}


Alli.

III)

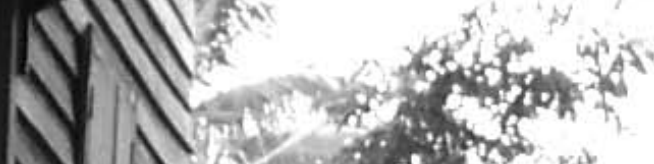

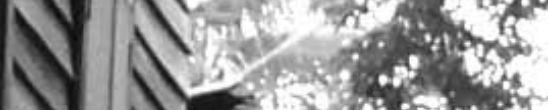

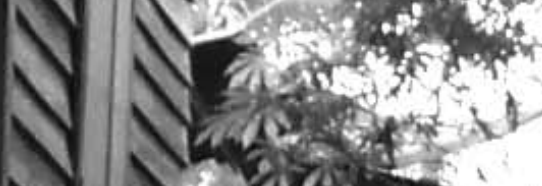

$\sqrt{2}$

30

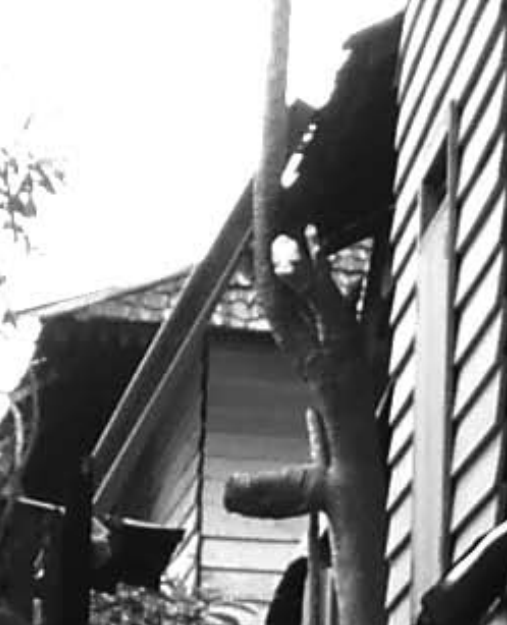

1.

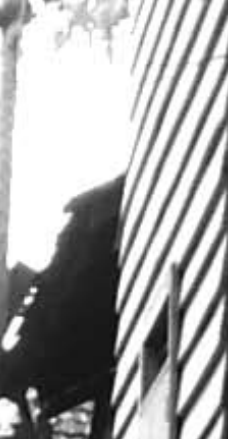

is

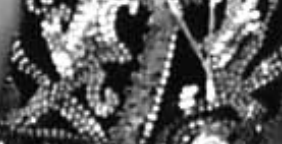

- 2

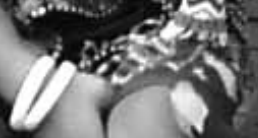

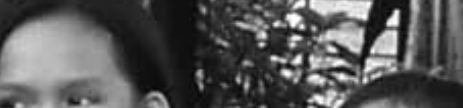

$r_{1}$

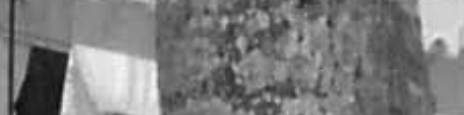

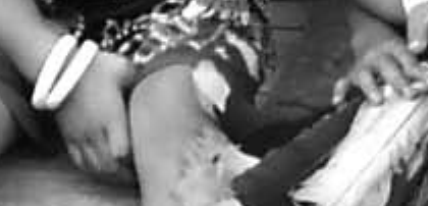

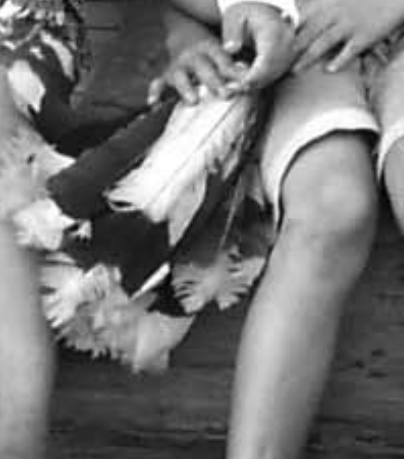

Cxin

fand
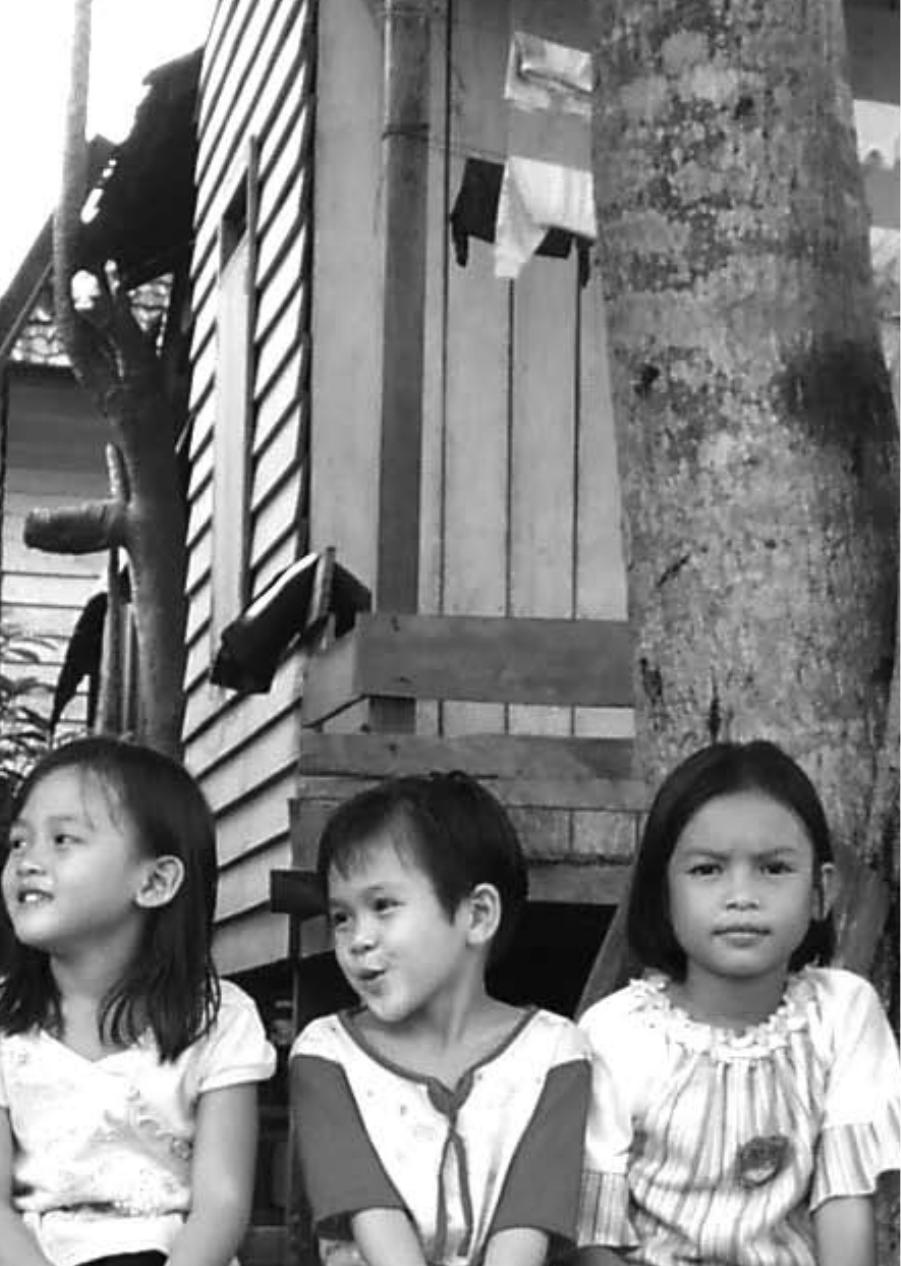

H N

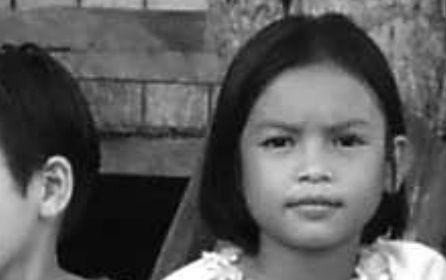

$1 x^{2} \rightarrow 0$
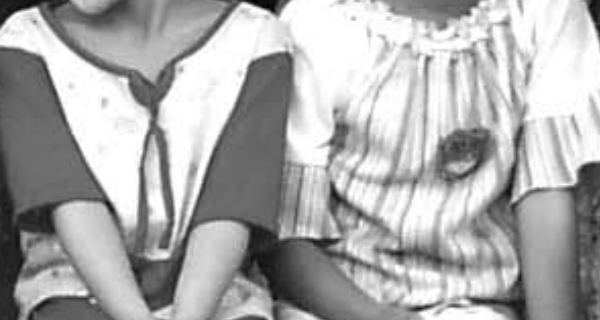

; $\rightarrow \infty$

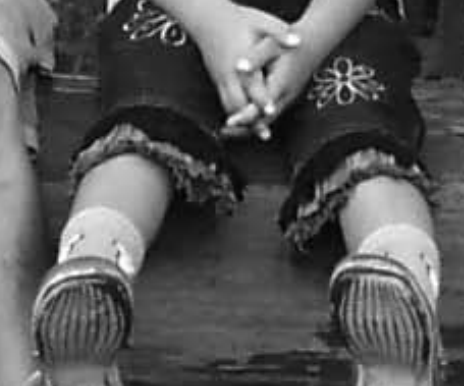

$-5$

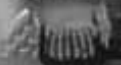

bit

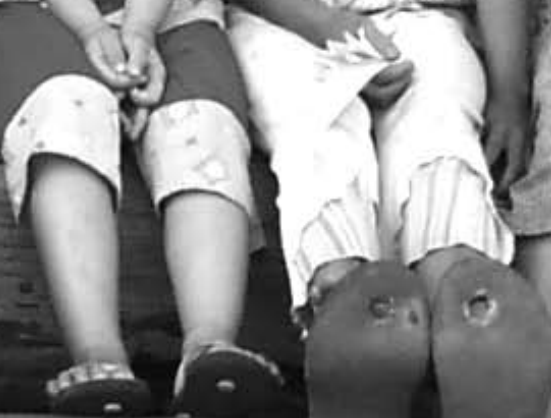


Lampiran 1. Daftar Peserta Lokakarya

\begin{tabular}{|c|c|c|}
\hline No & Nama & Institusi \\
\hline 1. & Ahmad Wijaya, S.Hut & $\begin{array}{l}\text { BIOMA } \\
\text { Jl. AW. Syahrani Kompleks Ratindo Blok F No } 7 \text { - } 8 \\
\text { Samarinda, Kalimantan Timur } \\
\text { Telephone: (0541) } 739864 \\
\text { Fax: (0541) } 739864\end{array}$ \\
\hline 2. & Abdi Riduansyah, Mr & $\begin{array}{l}\text { PT Amindo Wana Persada } \\
\text { Jl. Kartini No. } 21 \\
\text { Samarinda, Kalimantan Timur } \\
\text { Telephone: (0541) } 732205\end{array}$ \\
\hline 3. & Abdul Aziz, H. Ir.MMSi & $\begin{array}{l}\text { Dinas Kehutanan Kabupaten Paser } \\
\text { Jl.Jend Sudirman No.167 B } \\
\text { Tanah Grogot, Kalimantan Timur Telephone: (0543) } \\
22558 \\
\text { Fax:(0543) } 22558\end{array}$ \\
\hline 4. & Abdurrahman, $\mathrm{Mr}$ & $\begin{array}{l}\text { Balai Penelitian Kehutanan } \\
\text { Jl. A.W. Syahrani No.68, Sempaja } \\
\text { Samarinda, Kalimantan Timur } \\
\text { Telephone: (0541) } 206 \text { 364, } 203234 \text { Fax: (0541) } 742298\end{array}$ \\
\hline 5. & Aditya Bayunanda, Ir & $\begin{array}{l}\text { Lembaga Ekolabeling Indonesia/ } \\
\text { The Indonesian Ecolabelling Institute } \\
\text { Jl.Taman Malabar 18, Bogor } \\
\text { Telephone:(0251) 340744, } 340745 \\
\text { Fax:(0251) } 321739 \\
\text { email:dito@lei.or.id }\end{array}$ \\
\hline 6. & Agung Prasetyo, Ir.MSc & $\begin{array}{l}\text { Center for International Forestry Research (CIFOR) } \\
\text { Jl.CIFOR, Sindang Barang, Bogor } 16680 \\
\text { Telephone: (0251) } 622622 \\
\text { Fax:(0251) 622 100. } \\
\text { Email:a.prasetyo@cgiar.org }\end{array}$ \\
\hline 7. & Alfa Ratu S, S.Hut & $\begin{array}{l}\text { Tropenbos Indonesia - Kalimantan Program } \\
\text { Jl. Jenderal Sudirman, } \\
\text { Balikpapan Permai Blok K.1 No.12A } \\
\text { Balikpapan 76114, Kalimantan Timur } \\
\text { Telephone: (0542) } 820 \text { 503, 8250504 } \\
\text { Fax:(0542) } 735661\end{array}$ \\
\hline 8. & Alfan Subekti, Ir. MSc & $\begin{array}{l}\text { Tropenbos Indonesia - Kalimantan Program } \\
\text { Jl. Jenderal Sudirman, } \\
\text { Balikpapan Permai Blok K.1 No.12A } \\
\text { Balikpapan 76114, Kalimantan Timur } \\
\text { Telephone: (0542) } 820 \text { 503, 8250504 } \\
\text { Fax:(0542) } 735661\end{array}$ \\
\hline 9. & Alfian Noor, SP & $\begin{array}{l}\text { PT Timber Dana } \\
\text { Jl.Pipit No. 35, Bandara Temindung } \\
\text { Samarinda, Kalimantan Timur } \\
\text { Telephone: (0541) } 203722 \\
\text { Fax:(0541) } 203372\end{array}$ \\
\hline
\end{tabular}




\begin{tabular}{|c|c|c|}
\hline No & Nama & Institusi \\
\hline 10. & Anton Hidayat, Ir & $\begin{array}{l}\text { BIOMA } \\
\text { Jl. AW. Syahrani Kompleks Ratindo Blok F No } 7 \text { - } 8 \\
\text { Samarinda, Kalimantan Timur } \\
\text { Telephone: (0541) } 739864 \\
\text { Fax: (0541) } 739864\end{array}$ \\
\hline 11. & Ardiansyah, Mr & $\begin{array}{l}\text { PT Gunung Gajah A } \\
\text { Jl. AR. Hakim No 66, Kalimantan Timur }\end{array}$ \\
\hline 12. & Ardi Ansyah, Mr & $\begin{array}{l}\text { Pema, Kabupaten Paser } \\
\text { Jl. Negara Km } 83 \text { SMPN I Long Ikis } \\
\text { Paser, Kalimantan Timur }\end{array}$ \\
\hline 13. & Art Klassen, Dr & $\begin{array}{l}\text { Tropical Forest Foundation } \\
\text { Manggala Wanabhakti Building, } \\
\text { Block IV, } 7^{\text {th }} \text { Floor, Wing B } \\
\text { Jl. Jend. Gatot Subroto, Jakarta } \\
\text { Telephone: (021) } 5735589 \\
\text { Fax (021) } 57902925 \\
\text { Email: tff@cbn.net.id }\end{array}$ \\
\hline 14. & Awal Maryasa, Mr & $\begin{array}{l}\text { PT Inhutani I } \\
\text { Jl. Jend. Sudirman No. } 27 \\
\text { Balikpapan, Kalimantan Timur } \\
\text { Fax: (0542) } 420640\end{array}$ \\
\hline 15. & Awang $\mathrm{D}, \mathrm{Mr}$ & $\begin{array}{l}\text { PT Ratah Timber } \\
\text { Jl.P. Antasari No. } 61 \\
\text { Samarinda, Kalimantan Timur } \\
\text { Telephone: (0541) } 7011539\end{array}$ \\
\hline 16. & Ayi Suyana, Ir. & $\begin{array}{l}\text { Balai Penelitian Kehutanan } \\
\text { Jl. A.W. Syahrani No. 68, Sempaja } \\
\text { Samarinda, Kalimantan Timur } \\
\text { Telephone: (0541) } 206364,203234 \\
\text { Fax: (0541) } 742298\end{array}$ \\
\hline 17. & Boby Bayu P, Ir & $\begin{array}{l}\text { PT Sumalindo Lestari Jaya } \\
\text { Jl. Kedondong V No. } 110 \\
\text { Samarinda, Kalimantan Timur }\end{array}$ \\
\hline 18. & Bondan.P.H, Ir & $\begin{array}{l}\text { APHI/PT Inhutani II } \\
\text { Jl. Markisa No. } 7 \\
\text { Samarinda, Kalimantan Timur } \\
\text { Telephone: (0541) } 201005 \\
\text { Fax:(0541) } 735100\end{array}$ \\
\hline 19. & Chairul Saleh, Mr & $\begin{array}{l}\text { WWF - Indonesia } \\
\text { Kantor Taman A9, Unit A - 1, } \\
\text { Kawasan Mega Kuningan, Jakarta } 12950 \\
\text { Telephone:(021) } 5761070 \\
\text { Fax:(021) } 5761080 \\
\text { email:csaleh@wwf.or.id }\end{array}$ \\
\hline 20. & Dedi Rahdiansyah, S.Hut & $\begin{array}{l}\text { PT Karya Lestari } \\
\text { Samarinda, Kalimantan Timur }\end{array}$ \\
\hline
\end{tabular}




\begin{tabular}{|c|c|c|}
\hline No & Nama & Institusi \\
\hline 21. & Deni Wahyudi, S.Hut & $\begin{array}{l}\text { Tropenbos Indonesia - Kalimantan Program. } \\
\text { Jl. Jenderal Sudirman, } \\
\text { Balikpapan Permai Blok K.1 No.12A } \\
\text { Balikpapan 76114, Kalimantan Timur } \\
\text { Telephone: (0542) } 820 \text { 503, 8250504 } \\
\text { Fax:(0542) } 735661\end{array}$ \\
\hline 22. & Desi Wardayani, S.Hut & $\begin{array}{l}\text { Dinas Kehutanan Kabupaten Paser } \\
\text { Jl. Jend. Sudirman No. 167B } \\
\text { Tanah Grogot, Kalimantan Timur } \\
\text { Telephone: (0543) } 22558 \\
\text { Fax:(0543) } 22558\end{array}$ \\
\hline 23. & Edison Siahaan, Ir & $\begin{array}{l}\text { PT. Inhutani I } \\
\text { Jl. Jend. Sudirman No. } 27 \\
\text { Balikpapan, Kalimantan Timur } \\
\text { Fax: (0542) } 420640\end{array}$ \\
\hline 24. & Elisabeth Wetik, Ms & $\begin{array}{l}\text { Tropenbos Indonesia - Kalimantan Program. } \\
\text { Jl. Jenderal Sudirman, } \\
\text { Balikpapan Permai Blok K.1 No. 12A } \\
\text { Balikpapan 76114, Kalimantan Timur } \\
\text { Telephone: (0542) } 820 \text { 503, 8250504 } \\
\text { Fax:(0542) } 735661\end{array}$ \\
\hline 25. & Enggar Setyabudi, Ir & Balai Diklathut Samarinda \\
\hline 26. & Esmeralda Ardini, Ms & $\begin{array}{l}\text { Tropenbos Indonesia - Kalimantan Program. } \\
\text { Jl. Jenderal Sudirman, } \\
\text { Balikpapan Permai Blok K.1 No 12A, } \\
\text { Balikpapan 76114, Kalimantan Timur } \\
\text { Telephone: (0542) } 820 \text { 503, } 8250504 \\
\text { Fax:(0542) } 735661\end{array}$ \\
\hline 27. & Farida H.Susanty, Ir & $\begin{array}{l}\text { Balai Penelitian Kehutanan } \\
\text { Jl. A.W. Syahrani No. 68, Sempaja } \\
\text { Samarinda, Kalimantan Timur } \\
\text { Telephone: (0541) } 206364,203234 \\
\text { Fax: (0541) - 742 } 298\end{array}$ \\
\hline 28. & Gusti Hardiansyah, Ir.MSc & $\begin{array}{l}\text { PT Alas Kusuma Group } \\
\text { Jln. Adi Sucipto, Km 5,3 } \\
\text { Pontianak, Kalimantan Barat } \\
\text { Telephone: (0561) 721866 } \\
\text { Fax:(0561) 725 028/721583. } \\
\text { Email:phcab@telkom.net }\end{array}$ \\
\hline 29. & Hajar Dewanto, Mr & $\begin{array}{l}\text { PT Inhutani II } \\
\text { Jl. Markisa No. 7, Samarinda Kalimantan Timur } \\
\text { Telephone: (0541) } 201005 \\
\text { Fax:(0541) } 735100\end{array}$ \\
\hline 30. & Hamid, Mr & $\begin{array}{l}\text { PT Sumalindo Lestari Jaya } \\
\text { Samarinda, Kalimantan Timur }\end{array}$ \\
\hline
\end{tabular}




\begin{tabular}{|c|c|c|}
\hline No & Nama & Institusi \\
\hline 31. & Hari Priyadi, Ir. MSc & $\begin{array}{l}\text { Center for International Forestry Research (CIFOR) } \\
\text { Jl.CIFOR, Sindang Barang, Bogor } 16680 \\
\text { Telephone:(0251) } 622622 \\
\text { Fax (0251) } 622100 \\
\text { email: } \text { hpriyadi@cgiar.org }\end{array}$ \\
\hline 32. & Hasbillah, Ir & $\begin{array}{l}\text { Tropical Forest Foundation } \\
\text { Manggala Wanabhakti Building, } \\
\text { Block IV, } 7^{\text {th }} \text { Floor, } \\
\text { Jl. Jend. Gatot Subroto, Jakarta } \\
\text { Telephone: (021) } 5735589 \\
\text { Fax:(021) } 57902925 \\
\text { Email:tff@cbn.net.id }\end{array}$ \\
\hline 33. & I Wayan Sujana, Ir & $\begin{array}{l}\text { PT Roda Mas } \\
\text { J.P. Antasari No. 61, } \\
\text { Samarinda, Kalimantan Timur } \\
\text { Telephone: (0541) } 7011539\end{array}$ \\
\hline 34. & Irwan Gunawan, S.Hut & $\begin{array}{l}\text { WWF - Indonesia } \\
\text { Kantor Taman A9, Unit A - 1, } \\
\text { Kawasan Mega Kuningan, Jakarta } 12950 \\
\text { Telephone:(021) } 5761070 \\
\text { Fax:(021) } 5761080 \\
\text { email: igunawan@wwf.or.id }\end{array}$ \\
\hline 35. & Joko Sarjito, Mr & $\begin{array}{l}\text { PT Sumalindo Lestari Jaya } \\
\text { Jl. Kedondong V No.110 } \\
\text { Samarinda, Kalimantan Timur }\end{array}$ \\
\hline 36. & Kresno Santosa, Ir. MSi & $\begin{array}{l}\text { Center for International Forestry Research (CIFOR) } \\
\text { Jl.CIFOR, Sindang Barang, Bogor } 16680 \\
\text { Telephone: (0251) } 622622 \\
\text { Fax:(0251) } 622100 \\
\text { email: ksantosa@cgiar.org }\end{array}$ \\
\hline 37. & $\begin{array}{l}\text { Listya Kusumawardani, } \\
\text { Ir.MSc }\end{array}$ & $\begin{array}{l}\text { Bina Produksi Kehutanan (BPK) } \\
\text { Departemen Kehutanan } \\
\text { Gd.Manggala Wanabhakti } \\
\text { Jl.Gatot Subroto, Jakarta } \\
\text { Email: listya@dephut.go.id }\end{array}$ \\
\hline 38. & Loy Jones, Dr & $\begin{array}{l}\text { SmartWood Program - Rainforest Alliance } \\
\text { Wisma Anugraha, Lt. 1., } \\
\text { Jl.Taman Kemang 32B } \\
\text { Jakarta Selatan } 12730 \\
\text { Telephone: (021) } 71790038 . \\
\text { Fax: (021) } 71792123\end{array}$ \\
\hline 39. & M. Ibrahim, Mr & $\begin{array}{l}\text { PT KBT } \\
\text { JI.P. Antasari No } 61 \\
\text { Samarinda, Kalimantan Timur } \\
\text { Telephone: (0541) } 7011539\end{array}$ \\
\hline
\end{tabular}




\begin{tabular}{|c|c|c|}
\hline No & Nama & Institusi \\
\hline 40. & M. Reza Prihadi, Ir & $\begin{array}{l}\text { PT. Sumalindo Lestari Jaya } \\
\text { Jl. Kedondong V No. } 110 \\
\text { Samarinda, Kalimantan Timur }\end{array}$ \\
\hline 41. & M.A.Sardjono, Prof & $\begin{array}{l}\text { Universitas Mulawarman } \\
\text { Samarinda, Kalimantan Timur } \\
\text { Telephone: (0541) } 206407 \\
\text { Email:csf@samarinda.org }\end{array}$ \\
\hline 42. & Nani Djoko & $\begin{array}{l}\text { Center for International Forestry Research (CIFOR) } \\
\text { Jl. CIFOR, Sindang Barang, Bogor } 16680 \\
\text { Telephone: (0251) } 622622 \\
\text { Fax: (0251) } 622100\end{array}$ \\
\hline 43. & Nurcahyo Adi, Ir. MBA & $\begin{array}{l}\text { WWF - Indonesia } \\
\text { Kantor Taman A9, Unit A - 1, } \\
\text { Kawasan Mega Kuningan, Jakarta } 12950 \\
\text { Telephone:(021) } 5761070 \\
\text { Fax:(021) } 5761080 \\
\text { email: nadi@wwf.or.id }\end{array}$ \\
\hline 44. & Petrus Gunarso, Dr & $\begin{array}{l}\text { Center for International Forestry Research (CIFOR) } \\
\text { Jl.CIFOR, Sindang Barang, Bogor } 16680 \\
\text { Telephone: (0251) } 622622 \\
\text { Fax: (0251) 622 100 } \\
\text { email:pgunarso@cgiar.org }\end{array}$ \\
\hline 45. & Purnama Sari, S.Hut & $\begin{array}{l}\text { Dinas Kehutanan Kabupaten Paser } \\
\text { Jl. Jend Sudirman No. } 167 \text { B } \\
\text { Tanah Grogot, Kalimantan Timur } \\
\text { Telephone: (0543) } 22558 \\
\text { Fax: (0543) } 22558\end{array}$ \\
\hline 46. & Retno Wulandari, S.Hut & $\begin{array}{l}\text { Tropenbos Indonesia - Kalimantan Program } \\
\text { Jl. Jenderal Sudirman, } \\
\text { Balikpapan Permai Blok K.1 No.12A } \\
\text { Balikpapan 76114, Kalimantan Timur } \\
\text { Phone: (0542) } 820503,8250504 \\
\text { Fax: (0542) } 735661\end{array}$ \\
\hline 47. & Rusdi Manaf, Ir. H.MSi & $\begin{array}{l}\text { Kepala Dinas Kehutanan (PIt) } \\
\text { Provinsi Kalimantan Timur } \\
\text { Jl. Kenari I/99, } \\
\text { Samarinda, Kalimantan Timur }\end{array}$ \\
\hline 48. & Sigit Budi, Mr & $\begin{array}{l}\text { Planologi Balikpapan } \\
\text { Telephone: (0542) } 765683\end{array}$ \\
\hline 49. & Slamet, Mr & $\begin{array}{l}\text { PT Sumalindo Lestari Jaya } \\
\text { Jl. Kedondong V No. } 110 \\
\text { Samarinda, Kalimantan Timur }\end{array}$ \\
\hline 50. & Soeyitno S, Prof & $\begin{array}{l}\text { Fakultas Kehutanan } \\
\text { Universitas Mulawarman } \\
\text { Samarinda, Kalimantan Timur }\end{array}$ \\
\hline
\end{tabular}




\begin{tabular}{|c|c|c|}
\hline No & Nama & Institusi \\
\hline 51. & Sri Wahyudi, Ms & $\begin{array}{l}\text { PT Ratah Timber } \\
\text { Jl.P. Antasari No. } 61 \\
\text { Samarinda, Kalimantan Timur } \\
\text { Telephone: (0541) } 7011539\end{array}$ \\
\hline 52. & Sri Wahyuliana, Ir & $\begin{array}{l}\text { PT Timber Dana } \\
\text { Jl.Pipit No 35, Bandara Temindung } \\
\text { Samarinda, Kalimantan Timur } \\
\text { Telephone: (0541) } 203722 \\
\text { Fax:(0541) } 203372\end{array}$ \\
\hline 53. & Suherianto, Mr & $\begin{array}{l}\text { PT Roda Mas } \\
\text { Jl.P. Antasari No. } 61 \\
\text { Samarinda, Kalimantan Timur } \\
\text { Telephone: (0541) } 7011539\end{array}$ \\
\hline 54. & Sulistyo A Siran, Ir. MSc & $\begin{array}{l}\text { Balai Penelitian Kehutanan } \\
\text { Jl. A.W. Syahrani No. 68, Sempaja } \\
\text { Samarinda, Kalimantan Timur } \\
\text { Telephone: (0541) } 206364,203234 \\
\text { Fax: (0541) - 742 } 298\end{array}$ \\
\hline 55. & Susilo Hartono, Mr & $\begin{array}{l}\text { PT DSN } \\
\text { Jl. Bung Tomo } \\
\text { Samarinda, Kalimantan Timur } \\
\text { Telephone: (0541) } 261815\end{array}$ \\
\hline 56. & Susilo, Mr & $\begin{array}{l}\text { PT Rizki } \\
\text { Simpang Pait Long Ikis, } \\
\text { Kab. Paser, Kalimantan Timur }\end{array}$ \\
\hline 57. & Sutan Lubis, Ir & $\begin{array}{l}\text { Tropenbos Indonesia - Kalimantan Program. } \\
\text { Jl. Jenderal Sudirman } \\
\text { Balikpapan Permai Blok K.1 No. 12A } \\
\text { Balikpapan 76114, Kalimantan Timur } \\
\text { Telephone: (0542) } 820 \text { 503, 8250504 } \\
\text { Fax:(0542) } 735661\end{array}$ \\
\hline 58. & Sutrisno, Mr & $\begin{array}{l}\text { PT HAM } \\
\text { Jl. Imam Bonjol }\end{array}$ \\
\hline 59. & Syahrani, Mr & $\begin{array}{l}\text { PT KBT } \\
\text { Jl. P. Antasari No. } 61 \\
\text { Samarinda, Kalimantan Timur } \\
\text { Telephone: (0541) } 7011539\end{array}$ \\
\hline 60. & Tetra Yanuariadi, Dr & $\begin{array}{l}\text { WWF - Indonesia } \\
\text { Kantor Taman A9, Unit A - 1, } \\
\text { Kawasan Mega Kuningan, Jakarta } 12950 \\
\text { Telephone: (021) } 5761070 \\
\text { Fax:(021) } 5761080 \\
\text { email: tyanuariadi@wwf.or.id }\end{array}$ \\
\hline
\end{tabular}




\begin{tabular}{|l|l|l|}
\hline No & \multicolumn{1}{|c|}{ Nama } & \multicolumn{1}{c|}{ Institusi } \\
\hline 61. & Toa Suganda, Mr & $\begin{array}{l}\text { Tropenbos Indonesia - Kalimantan Program } \\
\text { Jl. Jenderal Sudirman, } \\
\text { Balikpapan Permai Blok K.1 No. 12A } \\
\text { Balikpapan 76114, Kalimantan Timur } \\
\text { Telephone: (0542) 820 503, 8250504 } \\
\text { Fax:(0542) 735 661 }\end{array}$ \\
\hline 62. & Yosef Ruslim, Dr & $\begin{array}{l}\text { The Natural Conservancy } \\
\text { Email:yruslim@samarinda.org }\end{array}$ \\
\hline 63. & $\begin{array}{l}\text { Yukina Uitenboogaart, } \\
\text { Ms }\end{array}$ & $\begin{array}{l}\text { Center for International Forestry Research (CIFOR) } \\
\text { Jl.CIFOR, Sindang Barang, Bogor 16680 } \\
\text { Telephone: (0251) 622 622 } \\
\text { Fax (0251) 622 100 }\end{array}$ \\
\hline 64. & Yulius Kayadi, S.Hut & $\begin{array}{l}\text { PT. Hanurata } \\
\text { Jl. Hidayatullah, Samarinda, Kalimantan Timur } \\
\text { Telephone: (0541) 737 082 }\end{array}$ \\
\hline
\end{tabular}


Lampiran 2. Agenda Lokakarya

\begin{tabular}{|c|c|c|c|}
\hline Waktu & Materi/Acara & Pembicara & Moderator \\
\hline \multicolumn{4}{|c|}{ Hari-1, Rabu 21 Juni 2006} \\
\hline $08.00-09.00$ & Pendaftaran peserta & & \\
\hline $09.00-09.30$ & $\begin{array}{ll}\text { Pembukaan: } \\
\text { - } & \text { Sambutan } \\
& \text { Penyelenggara } \\
\text { - } & \text { Sambutan Kepala Dinas } \\
& \text { Kehutanan Provinsi } \\
& \text { Kaltim } \\
\text { - } & \text { Sambutan Dirjen BPK }\end{array}$ & $\begin{array}{ll}\text { - } & \text { Dr. Petrus Gunarso } \\
\text { (Direktur MRF } \\
\text { - CIFOR) } \\
\text { - } \\
\text { Bpk. Ir. H. Rusdi } \\
\text { Manaf, Msi } \\
\text { - } & \text { Listya Wardani } \\
\text { (Direktur Penyiapan } \\
\text { Pengusahaan } \\
\text { Hutan Produksi) }\end{array}$ & \\
\hline $09.30-10.00$ & Rehat kopi & & \\
\hline $10.00-12.30$ & $\begin{array}{l}\text { Presentasi dan diskusi sesi } 1 . \\
\text { Tata Kelola Pemerintahan } \\
\text { yang baik (Good Corporate } \\
\text { Governance): } \\
\text { - Gambaran umum Tata } \\
\text { Kelola Hutan Yang Baik } \\
\text { - } \quad \text { Peranan Pelaku Usaha } \\
\text { Kehutanan Menuju Tata } \\
\text { Kelola Hutan yang Baik } \\
\text { (Sebuah Pembelajaran) } \\
\text { - } \quad \text { Peranan Kelompok- } \\
\text { Kelompok Kerja } \\
\text { Sertifikasi dalam } \\
\text { Mewujudkan Tata Kelola } \\
\text { Hutan yang Baik } \\
\text { Tantangan dan } \\
\text { Kesempatan Sertifikasi } \\
\text { dalam Pasar Global }\end{array}$ & $\begin{array}{l}\text { - Ir. Alfan Subekti, } \\
\text { MSc (TBI) } \\
\text { - } \begin{array}{l}\text { Ir. Agung Prasetyo } \\
\text { MSc (CIFOR) }\end{array} \\
\text { - Prof. Soeyitno } \\
\begin{array}{l}\text { Soedirman (KKS/ } \\
\text { Unmul) }\end{array} \\
\text { - Mr. Loy Jones } \\
\text { (Smartwood) }\end{array}$ & $\begin{array}{l}\text { Prof. Dr. Mustofa } \\
\text { Agung Sardjono } \\
\text { (UNMUL/CSF) }\end{array}$ \\
\hline $12.30-13.30$ & Makan siang & & \\
\hline $13.30-15.30$ & $\begin{array}{l}\text { Presentasi dan diskusi sesi } 2 . \\
\text { RIL dan Pembelajarannya: } \\
\text { - } \quad \text { Konsep dan manfaat RIL } \\
\text { - } \quad \text { Pembelajaran dari PT } \\
\quad \text { Sari Bumi Kusuma } \\
\text { - Pembelajaran dari PT } \\
\quad \text { Sumalindo ayu }\end{array}$ & $\begin{array}{ll}\text { - } & \text { Mr. Art Klassen dan } \\
\text { Ir. Hasbillah (TFF) } \\
\text { - } \quad \text { Ir. Gusti } \\
\text { Hardiyansyah MSC } \\
\text { - Ir. Boby Bayu (PT } \\
\text { SLJ) }\end{array}$ & $\begin{array}{l}\text { Ir. Hari Priyadi MSc } \\
\text { (CIFOR) }\end{array}$ \\
\hline $15.30-16.00$ & Rehat kopi & & \\
\hline
\end{tabular}




\begin{tabular}{|c|c|c|c|}
\hline Waktu & Materi/Acara & Pembicara & Moderator \\
\hline $16.00-17.30$ & $\begin{array}{l}\text { Presentasi dan diskusi sesi } 3 . \\
\text { Sertifikasi dan Kehati pada } \\
\text { Hutan Produksi: } \\
\text { - } \quad \text { Sertifikasi Pengelolaan } \\
\text { Hutan Lestari } \\
\text { - } \quad \text { Program Nusa Hijau } \\
\text { - } \quad \text { Rencana Testing } \\
\text { Panduan ITTO/IUCN } \\
\text { untuk Konservasi } \\
\text { Keanekaragaman Hayati } \\
\text { di Hutan Produksi } \\
\text { - Panduan ITTO/IUCN } \\
\text { untuk Konservasi Kahati } \\
\text { di Hutan Produksi Tropik }\end{array}$ & $\begin{array}{ll}\text { - } & \text { Ir. Aditya } \\
& \text { Bayunanda (LEI) } \\
\text { - } & \text { Ir. Irwan Gunawan } \\
\text { (WWF) } \\
\text { - } & \begin{array}{l}\text { Dr.Tetra Yanuardi } \\
\text { (WWF) }\end{array} \\
& \\
\text { - } & \text { Dr. Petrus Gunarso } \\
\text { (CIFOR) }\end{array}$ & $\begin{array}{l}\text { Ir. Alfan Subekti, } \\
\text { MSc (Tropenbos) }\end{array}$ \\
\hline $17.30-18.30$ & $\begin{array}{l}\text { Briefing untuk evaluasi hari } 1 \\
\text { dan skenario hari ke-2 }\end{array}$ & & \\
\hline \multicolumn{4}{|c|}{ Hari-2, Kamis 22 Juni 2006} \\
\hline $08.00-09.00$ & Registrasi peserta & & \\
\hline $09.00-10.30$ & $\begin{array}{ll}\text { Diskusi Kelompok: } \\
\text { - } & \text { Kelompok 1. RIL dan } \\
& \text { Pembelajarannya } \\
\text { - } & \text { Kelompok } 2 \text { Sertifikasi } \\
& \text { dan Keanekaragaman } \\
& \text { Hayati }\end{array}$ & & 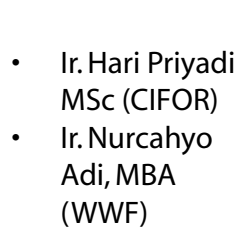 \\
\hline $10.30-11.00$ & Rehat kopi & & \\
\hline $11.00-12.30$ & $\begin{array}{l}\text { Presentasi Kelompok dan } \\
\text { Diskusi Pleno } \\
\text { - Kelompok 1.RIL dan } \\
\text { Pembelajarannya } \\
\text { - Kelompok } 2 \text { Sertifikasi } \\
\text { dan Keanekaragaman } \\
\text { Hayati }\end{array}$ & $\begin{array}{ll}\text { - } & \text { Dr. Yosef Ruslim } \\
\text { (TNC/Unmul) } \\
\text { - } & \text { Joko Sarjito (PT SLJ) }\end{array}$ & $\begin{array}{l}\text { Dr. Petrus } \\
\text { Gunarso (CIFOR) }\end{array}$ \\
\hline $12.30-13.30$ & Makan siang & & \\
\hline $13.30-14.30$ & $\begin{array}{l}\text { Pembahasan Kesimpulan } \\
\text { Diskusi Kelompok }\end{array}$ & & $\begin{array}{l}\text { Dr. Petrus } \\
\text { Gunarso (CIFOR) }\end{array}$ \\
\hline $14.30-15.00$ & $\begin{array}{l}\text { Pembacaan Kesimpulan dan } \\
\text { rekomendasi }\end{array}$ & $\begin{array}{l}\text { Prof. Mustofa Agung } \\
\text { Sardjono }\end{array}$ & \\
\hline $15.00-15.15$ & Penutupan & & $\begin{array}{l}\text { Dr. Petrus } \\
\text { Gunarso/CIFOR }\end{array}$ \\
\hline
\end{tabular}


Center for International Forestry Research (CIFOR) adalah lembaga penelitian kehutanan internasional terdepan, yang didirikan pada tahun 1993 sebagai tanggapan atas keprihatinan dunia akan konsekuensi sosial, lingkungan dan ekonomi yang disebabkan oleh kerusakan dan kehilangan hutan. Penelitian CIFOR ditujukan untuk menghasilkan kebijakan dan teknologi untuk pemanfaatan dan pengelolaan hutan yang berkelanjutan, dan untuk meningkatkan kesejahteraan masyarakat di negara-negara berkembang yang bergantung kepada hutan tropis untuk kehidupannya. CIFOR adalah salah satu di antara 15 pusat Future Harvest di bawah Consultative Group on International Agricultural Research (CGIAR). Berpusat di Bogor, Indonesia, CIFOR mempunyai kantor regional di Brazil, Burkina Faso, Kamerun dan Zimbabwe, dan bekerja di lebih dari 30 negara di seluruh dunia. 
Pengelolaan hutan lestari sangat tergantung pada rentang dan kualitas kebijakan pemungkin sebagaimana halnya kondisi hukum dan kelembagaan yang menjadi landasan bagi tata kelola hutan yang baik. Hubungan kemitraan antara pemerintah, sektor swasta, dan masyarakat merupakan faktor penting dalam mencapai kearah tersebut.

Aspek hukum dan peraturan telah tersedia dengan baik dan iklim usaha yang mendukung bagi pihak swasta diharapkan dapat mendorong pihak swasta untuk menerapkan prinsip-prinsip praktek kehutanan terbaik (best forest practices) dengan cara memberikan manfaat bagi masyarakat lokal. Aktivitas-aktivitas tersebut menjawab kebutuhan untuk membangun kemitraan antara berbagai pihak yang aktif menuju peningkatan tata kelola hutan di Kalimantan dengan pasar internasional.

Prosiding ini merupakan kumpulan dari keseluruhan acara lokakarya: Menuju Tata Kelola Hutan yang Baik "Peningkatan Implementasi Pengelolaan Hutan Lestari melalui Sertifikasi Hutan dan Pembalakan Ramah Lingkungan"yang diselenggarakan oleh CIFOR dan The Forest Partnership (Tropenbos - CIFOR - WWF) pada tanggal 21-23 Juni 2006 di Balikpapan. Prosiding ini berisi sambutan, kerangka acuan, presentasi, tanya jawab, hasil-hasil diskusi kelompok, rumusan hasil diskusi pleno, rumusan hasil lokakarya dan rekomendasi.
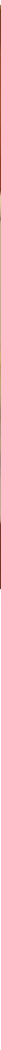